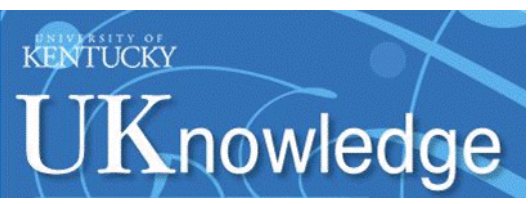

Kentucky Law Journal

\title{
Civil Rights for Whom?: Gay Rights Versus Religious Freedom
}

George W. Dent Jr.

Case Western Reserve University

Follow this and additional works at: https://uknowledge.uky.edu/klj

Part of the Civil Rights and Discrimination Commons, Constitutional Law Commons, and the Sexuality and the Law Commons

Right click to open a feedback form in a new tab to let us know how this document benefits you.

\section{Recommended Citation}

Dent, George W. Jr. (2007) "Civil Rights for Whom?: Gay Rights Versus Religious Freedom," Kentucky Law Journal: Vol. 95: Iss. 3, Article 2.

Available at: https://uknowledge.uky.edu/klj/vol95/iss3/2

This Article is brought to you for free and open access by the Law Journals at UKnowledge. It has been accepted for inclusion in Kentucky Law Journal by an authorized editor of UKnowledge. For more information, please contact UKnowledge@lsv.uky.edu. 


\title{
Civil Rights for Whom?: Gay Rights Versus Religious Freedom
}

\author{
George W. Dent, Jr. \\ Table of Contents
}

INTRODUCTION . . . . . . . . . . . . . . . . . . . . . 555

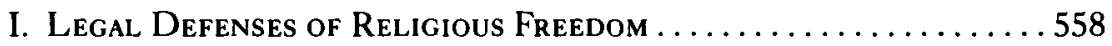

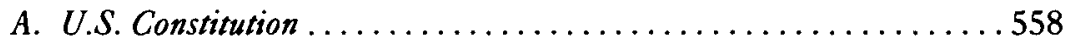

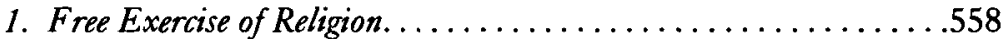

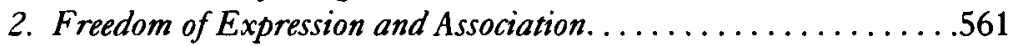

3. The Establishment Clause. .................. 562

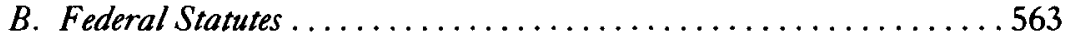

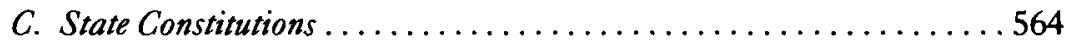

D. State Statutes. . . . . . . . . . . . . . . . . . . . 565

II. Government Action Supporting Homosexuality. . . . . . . . 565

A. Laws Governing Private Employers and Service Providers. . . . . . . 565

1. Discrimination Based on Homosexuality. ..............565

2. Does Discrimination Based on Homosexuality Constitute

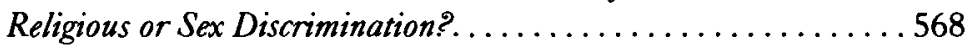

3. Private Service and Housing Providers. . . . . . . . . . . . . . 569

4. Business Entities as Expressive or Religious Organizations. . . . . 572

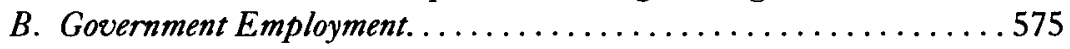

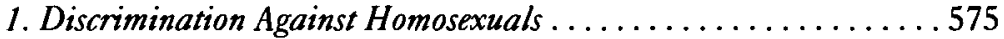

2. The Religious Freedom of Government Employees. . . . . . . 577

a. Lumpkin v. Brown. ... . . . . . . . . . . . . . . 577

b. Good News Employee Association v. Hicks . . . . . . . . . 578

c. Downs v. Los Angeles Unified School District. . . . . . . . 580

d. Mississippi Commission on Judicial

Performance v. Wilkerson . . . . . . . . . . . . . . . . . . 580

$e$. Vernon v. City of Los Angeles . . . . . . . . . . . . .583

f. Altman v. Minnesota Department of Corrections . . . . . . 585

g. Akridge v. Wilkinson .................. 585

I Schott-van den Eynden Professor of Law, Case Western Reserve University School of Law. The author thanks Rick Duncan, Jonathan Entin, Maggie Gallagher, and Jessie Hill for their helpful comments, and thanks Judy Kaul, Justin Hughes, and Christopher Boeman for their excellent research assistance. 
h. Speech Codes ................................ 586

i. Religious Judges ............................ 586

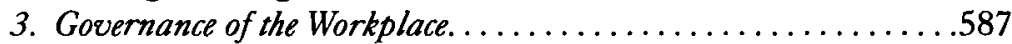

C. Government Contractors. ......................... 588

1. Okwedy v. Molinari .......................... 589

2. Catholic Charities of Maine, Inc. v. City of Portland ...... 590

3. Catholic Adoption Agencies in Massachusetts ...............591

4. The Salvation Army in San Francisco ................ 592

D. Use of Public Facilities. . . . . . . . . . . . . . . . . . . . . . . . . .592

E. Students in Public Educational Institutions. . .............. 595

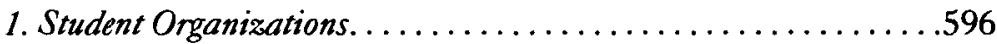

2. Individual Students. ...........................598

3. University Speech Codes and Thought Control............. 603

4. Use of University Facilities and School-Subsidized Activities. . . . 608

F. Government Endorsement of Homosexuality. ..............6 608

G. Regulation of Expressive Associations. ...................614

H. Griminal Law. .................................618

1. Federal Law. . . . . . . . . . . . . . . . . . . . . . . 618

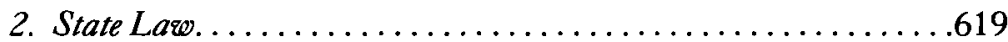

I. Raising Children. .............................620

III. Religious Freedom in Private Organizations. . . . . . . . . 621

A. The Private Workplace..............................621

1. Bodett v. Coxcomb, Inc........................621

2. Peterson v. Hewlett-Packard. .....................624

3. Buonanno v. AT\&T Broadband. ..................626

4. Bruff v. North Mississippi Health Services, Inc. .........627

B. Private Colleges and Universities. .................. 627

IV. Resolving the Conflict. . . . . . . . . . . . . . . . . . . . . 628

A. General Principles. .............................628

B. The Case For (and Against) Laws Supporting Homosexuality. . . . . 629

C. The Case For (and Against) Religious Freedom. . . ...........6. 633

D. Resolutions..................................636

1. Equal Rights or Special Rights? .................... 636

2. Equal Respect for Homosexuality? ...................637

3. Freedom of Expression............................6 640

4. Discrimination in Employment and Services..............642

5. The Expressive Role of Law and Government..............645

ConcLusion.....................................647 


\section{INTRODUCTION}

Disapproval of homosexuality is widespread, deep-rooted, and of long standing. Although some cultures have tolerated some homosexual acts, more often they have been condemned. In the West, including America, homosexual acts were often crimes, and society often shunned homosexuals. Many religions denounce homosexuality. For nearly 3,000 years the people of "the Book"-Jews, Christians, and Muslims-have deemed homosexuality a grave sin, but disapproval of homosexuality is so widespread that it cannot be ascribed to theology. More likely, most people have an innate distaste for homosexuality. Put another way, given human nature, heterosexuality can be considered intrinsically better, an aspect of human flourishing. Further, heterosexuality, and especially traditional marriage, have important benefits for society.

In the last forty years, however, a movement to change the treatment of homosexuality has emerged in parts of the West. This movement first sought only tolerance-the removal of legal burdens on homosexuality and an end to violence against homosexuals. Now the movement demands approval of homosexuality as legally and socially equal to heterosexuality. The demand for approval brings the gay movement into conflict with "traditional" religion. This conflict flares throughout our culture, from the portrayal of homosexuality in the media to its treatment in public schools. A key, if not paramount, battleground in this culture war is the law. In myriad contexts, from the right of university students to form Christian societies to the treatment by private employers of the gay partners of their employees, the gay movement is pressing for laws to require people and institutions to accept homosexuality regardless of their religious beliefs.

In many a skirmish in this war, the tangible stakes are small, even trivial. Even taken as a whole, the material interests may not be that great. Homo-

2 See the Torah (Leviticus 18:22, 20:13) (Jewish), the New Testament (Romans i:26-28, 1 Timothy I:9-10, I Corinthians 6:9-10) (Christian), and the Koran (The Heights 7:80) (Moslem). See generally Warken J. Blumenfeld \& Diane Raymond, Looking at Gay and Lesbian Life 152-217 (1988).

3 See infra notes $560-63$ and accompanying text.

4 See infra notes 564-73 and accompanying text.

5 Not all religions resist the demand. Although it is hard to find any acceptance of homosexuality in Judaism or Christianity until the last few decades, some of their branches now condone homosexuality. This Article calls sects that reject equality "traditional." The term is imprecise since attitudes toward the gay movement range from enthusiastic support to blanket rejection, but it includes Orthodox Judaism, Roman Catholicism, and most Muslim and evangelical Protestant congregations.

6 See Joseph P. Shapiro \& Gareth G. Cook, Straight Talk About Gays, U.S. News \& WorLD REP., July 5, 1993, at 47, 48 (stating that "laws are often the first step toward changing hearts and minds"). See generally James Davison Hunter, Culture Wars: The Struggle to Define America (1991). Hunter lists law as one of the five fiercest battlegrounds in this war. Id. at 173 . 
sexuals have considerable economic and political power; in a free market democracy most businesses and governments will not want to antagonize this constituency. Even religious organizations that consider homosexual acts a sin often eschew discrimination against homosexuals in most spheres, including employment.

Yet this war is not amenable to compromise. Again, the goal of the gay movement is not primarily economic; most gays already have above-average incomes. ${ }^{7}$ The goal, rather, is approval of homosexuality as legally and socially equal to heterosexuality. ${ }^{8}$ Because of the tremendous influence of religion in America, this goal cannot be achieved unless religious groups either surrender, thus affirming this equality or, at least, those that do not are reduced to a despised minority compelled to keep its views to itself. In other words, the goal of the gay movement is to confine its opponents in the closet.

Since the gay movement's goals are not primarily economic, it cares about the law not so much for its financial impact as for its symbolic or expressive significance. ${ }^{9}$ Thus it matters little that only one employee registers for domestic partner benefits at a large university. What matters is that by offering such benefits the university announces to its constituents-students, alumni, faculty and staff-and to the world that it condones homosexuality. Since the prize is a symbol, compromise is unacceptable except, perhaps, as a temporary tactic: anything less than full equality is inferior, second-class status, intolerable. ${ }^{10}$

Full legal and social equality of homosexuality, however, cannot be squared with respect for the traditional religions that disapprove of homosexuality. If government treats homosexuality as equal to heterosexuality, and through nondiscrimination laws requires citizens to do likewise, then disparagement of homosexuality must be condemned and suppressed just as racial discrimination now is. In effect, government must declare traditional religion to be false and evil. Many homosexual activists openly embrace this goal. Marshall Kirk and Erastus Pill call for an attack on "the moral authority of homophobic churches by portraying them as antiquated backwaters, badly out of step with the times and with the latest findings

7 See Richard F. Duncan, Who Wants to Stop the Church: Homosexual Rights Legislation, Public Policy, and Religious Freedom, 69 Notre Dame L. Rev. 393, 408-09 (1994) (summarizing data); Hewitt, Socioeconomic Position of Gay Men: A Review of the Evidence, 54 Am. J. Econs. \& Soc. $46 \mathrm{I}$ (1995). However, a more complex and ambiguous picture is presented in M.V. LeE BADGETT, Money, Mrths, and Change: The Economic Lives of Lesbians and Gay Men (2001).

8 See Randy Shilts, The Queering of America, Advoc., Jan. 2, 1991, at 32-33 (stating that the "gay movement" is "essentially a battle for social legitimacy" and "[a]chieving ... cultural acceptability" of "homosexuality as an acceptable and viable means of expression, on a par with and equal to heterosexuality").

9 See infra notes 602-1 2 and accompanying text.

Io See id. 
of psychology." "Kirk and Hunter Madsen advise depicting traditionalists as "[h]ysterical backwoods preachers, drooling with hate to a degree that looks both comical and deranged." ${ }^{12}$ Traditional believers will not accept such treatment.

Perhaps we could aspire to legal neutrality, but it's unclear what neutrality would be here. ${ }^{13}$ In any case, no recipe for neutrality would satisfy either side. Presumably neutrality would include, for example, legal recognition of same-sex "marriages," which is anathema to traditional faiths. Neutrality presumably would also mean that individuals and private organizations would be free to discriminate based on sexual orientation, which is unacceptable to gay activists.

Arguably, local discretion could also abate, if not resolve, the conflict. Some locales might broadly endorse homosexuality through comprehensive nondiscrimination laws and through propaganda condoning homosexuality in public schools and elsewhere. Other locales could make homosexual sodomy a crime and bar homosexuals from public employment. This approach, too, is unacceptable to both sides. Each has routinely appealed to a higher level of government when it loses a local battle. The gay movement persuaded the Supreme Court to strike down criminal sodomy laws. When some state courts required validation of gay "marriages," the other side achieved enactment of the Defense of Marriage Act."

In any case, it is in practice impossible to leave this issue to local governments. Federal funding pervades many activities. In an integrated national economy there is always a case for uniform federal laws for matters like employment discrimination. More importantly, homosexuality concerns marriage and the family, every society's most basic institutions. Just as Lincoln believed that America could not "endure permanently, half slave and half free," ${ }^{16}$ so America cannot endure with two halves following radically different policies on marriage and the family. Again, this is a struggle over principle, so compromise seems impossible.

However, the legal war between religion and the gay movement will not culminate in an Armageddon, a final showdown. To achieve total victo-

I Marshall Kirk \& Erastus Pill, Waging Peace, Christopher St., Dec. 1984, at 33, 38 .

I 2 Marshall Kirk \& Hunter Madsen, After the Ball: How America Will Conquer Its Fear and Hatred of Gays in the 90's 189 (1989). Their goal is not only to change minds but to render traditional attitudes "so discreditable that even Intransigents will eventually be silenced in public...." Id.

I 3 It is unclear in general what neutrality means or whether it can have a coherent meaning, especially as applied to religion. See Douglas Laycock, Formal, Substantive and Disaggregated Neutrality Toreard Religion, 39 DePaul L. Rev. 993 (1990).

14 Lawrence v. Texas, 539 U.S. $55^{8}$ (2003).

15 Pub. L. No. 104-199, I 10 Stat. 2419 (1996) (codified as amended in scattered sections of $I$ and 28 U.S.C.).

I6 Abraham Lincoln, Speech (June 16, 1858), in The Oxford Dictionary of Quotations 421 (4th ed. 1992). 
ry, one side would need to obtain either a national law that would establish the full legal and social equality of homosexuality with no substantial religious exceptions; or a law making all claims of religious freedom trump any claim of gay rights. At least in this century such a triumph for either side is implausible." Even if it were politically feasible, it is hard to imagine what form any such law could take. Accordingly, the war between religion and the gay movement seems fated to drag on indefinitely in innumerable battles large and small.

Part I of this Article discusses general federal and state constitutions and statutes that set some boundaries for specific disputes. Part II discusses government action supporting homosexuality, including various antidiscrimination laws and religious exemptions therefrom. Part III discusses actions by private institutions against employees, students, or others who manifest traditional views about homosexuality. Part IV discusses general principles in the conflict between the gay movement and religious freedom and suggests some resolutions.

\section{Legal Defenses for Religious Freedom}

No federal law substantially protects religious freedom. The Supreme Court has rendered the Free Exercise Clause of the Constitution almost meaningless. ${ }^{18}$ However, the First Amendment rights of free speech and association also apply to religious activity and provide some shelter from government intrusion. ${ }^{19}$ In theory the Establishment Clause of the First Amendment also offers some protection by forbidding government action that deprecates a particular religion or religion generally, although in practice the scope of this protection is negligible. ${ }^{20}$ To offset the Supreme Court's gutting of the Free Exercise Clause, Congress enacted the Religious Freedom Restoration Act in 1993, but in 1997 the Supreme Court held it unconstitutional as applied to the states. ${ }^{21}$ There also is no federal law forbidding private discrimination against homosexuals or otherwise requiring private parties to respect homosexuality.

\section{A. The United States Constitution}

1. Free Exercise of Religion.-In Employment Division v. Smith, the Supreme Court declared: "the right of Free Exercise does not relieve an individual

17 Despite the forecasts of some gay activists, it is most unlikely that the gay movement can achieve dominance over the opposition soon, if ever. See infra notes 532-53 and accompanying text.

I 8 See infra notes 22-26 and accompanying text.

19 See infra notes $27-37$ and accompanying text.

20 See infra notes $51-52$ and accompanying text.

21 City of Boerne v. Flores, 52 I U.S. 507 (1997). 
of the obligation to comply with a 'valid and neutral law of general applicability on the ground that the law proscribes (or prescribes) conduct that his religion prescribes (or proscribes)." ${ }^{22}$ However, there may be broader "hybrid" rights when a claim of free exercise is conjoined "with other constitutional protections, such as freedom of speech and of the press, ... or the right of parents ... to direct the education of their children."

$S$ mith addresses only the rights of individuals under the Free Exercise Clause; the free exercise rights of religious organizations are arguably different. The Supreme Court has never granted a religious organization a free exercise exemption from any law and has on occasion denied such an exemption. ${ }^{24}$ However, the Court has never said that the free exercise right is the same for religious organizations as for individuals. Religious organizations have a distinctive social function; that is why we speak of separation of church and state but not separation of religious individuals and state. Lower courts have found a free exercise exemption for religious organizations from general antidiscrimination laws with respect to employees who perform priestly functions, ${ }^{25}$ but they have not exempted religiously affiliated social services organizations and schools from labor laws.

22 Employment Div. v. Smith, 494 U.S. 872, 879 (1990) (quoting United States v. Lee, 455 U.S. 252, 263 n.3 ( 1982 ) (Stevens, J., concurring in judgment)).

23 Id. at 88 I (footnote and citations omitted).

24 See Tony \& Susan Alamo Found. v. Sec'y of Labor, 47 I U.S. 290 (1985) (denying exemption from minimum wage and other provisions of the Fair Labor Standards Act); Bob Jones Univ. v. United States, 46I U.S. 574 ( 1983 ) (denying claim of tax-exempt status to private university that engaged in religiously motivated racial discrimination).

25 See, e.g., Werft v. Desert Sw. Annual Conference of the United Methodist Church, 377 F.3d 1099 (9th Cir. 2004); Elvig v. Calvin Presbyterian Church, 375 F.3d 951 (9th Cir. 2004); Alicea-Hernandez v. Catholic Bishop of Chicago, 320 F.3 698 (7th Cir. 2003); EEOC v. Roman Catholic Diocese of Raleigh, 2 I3 F.3d 795 (4th Cir. 2000); Gellington v. Christian Methodist Episcopal Church, Inc., 203 F.3d I 299 (I th Cir. 2000); Starkman v. Evans, 198 F.3d 173 (5th Cir. 1999); Bollard v. Cal. Province of the Soc'y of Jesus, 196 F.3d 940 (9th Cir. 1999); EEOC v. Catholic Univ. of Am., 83 F.3d 455 (D.C. Cir. 1996). The courts do not agree about what constitutes "ministerial functions." See Kathleen A. Brady, Religious Organizations and Free Exercise: The Surprising Lessons of Smith, 2004 BYU L. REv. 1633, 1653. An exemption may also prevail "where employment regulation conflicts with specific religious doctrines or practices." Id. at 1654-55. See generally G. Sidney Buchanan, The Power of Government to Regulate Class Discrimination by Religious Entities: A Study in Conficting Values, 43 EMoRY L.J. 1189 (1994).

26 See Brady, supra note 25, at 1656-6r. In Dignity Twin Cities v. Newman Center and Chapel, 472 N.W.2d 355 ( I991), the Minneapolis Civil Rights Commission found that the Catholic Church violated an ordinance forbidding discrimination based on affectional preference by refusing to renew a lease on space in a building it owned to an organization that rejected the Church's teaching on homosexuality. The court held that application of the ordinance here would be unconstitutional because it would create excessive state entanglement in religion. The holding is dubious; the court did not even cite Employment Division v. Smith. Even if it is correct, the decision has little precedential significance since most antidiscrimination laws exempt church activities. 
Although Smith severely restricts the Free Exercise Clause, legislatures may grant some accommodations of religion by statute without violating the Establishment Clause. "[I]t is a permissible legislative purpose to alleviate significant governmental interference with the ability of religious organizations to define and carry out their religious missions." ${ }^{27}$ The Court in Smith acknowledged the propriety of legislative accommodations. ${ }^{28}$ Congress has exempted religious organizations from prohibitions on religious discrimination in employment but not on discrimination based on gender, race, or age. ${ }^{29}$ The Supreme Court upheld the exemption for religious organizations from the antidiscrimination provisions of Title VII of the Civil Rights Act of $1964 .^{30}$ A legislative dispensation can extend to individuals as well as to organizations. Recently, the Court upheld the special protection of religious exercise for prisoners under the Religious Land Use and Institutionalized Persons Act. ${ }^{31}$ In so doing it said "[r]eligious accommodations ... need not "come packaged with benefits to secular entities.",32

Accommodations of religion do not violate the Establishment Clause if they are "designed to alleviate government intrusions that might significantly deter adherents of a particular faith from conduct protected by the Free Exercise Clause." ${ }^{33}$ However, the Supreme Court struck down an exemption from a state sales tax for the sale of religious literature by religious organizations. ${ }^{34}$ The court also invalidated a statute that granted employees an unqualified right not to work on their Sabbath, finding it had "a primary effect that impermissibly advances a particular religious practice."

At least for religious organizations, exemptions from laws barring discrimination against homosexuals seem clearly constitutional under Amos. Exemptions for individuals and non-religious organizations should also

27 Corp. of the Presiding Bishop of the Church of Jesus Christ of Latter-Day Saints v. Amos, 483 U.S. 327,335 (1987).

28 Smith, 494 U.S. at 890 .

29 Lower courts have refused to find an implied exemption. See Geary v. Visitation of the Blessed Virgin Mary Parish Sch., 7 F.3d 324, 331 (3d Cir. 1993); DeMarco v. Holy Cross High Sch., 4 F.3d 166, I 72-73 (2d Cir. 1993); Dole v. Shenandoah Baptist Church, 899 F.2d I389, 1394-95 (4th Cir. I990); EEOC v. Fremont Christian Sch., 78 I F.2d 1362, I365-66 (9th Cir. I986); EEOC v. Pac. Press Publ'g Ass'n, 676 F.2d 1272, 1276 (9th Cir. 1981); EEOC v. Miss. Coll., 626 F.2d 477, 485 (5th Cir. 1980). But see McClure v. Salvation Army, 460 F.2d 553, 560-61 (5th Cir. 1972).

30 Amos, 483 U.S. at 335 . Lower courts have expanded the exemption. See supra note 29 and accompanying text.

3142 U.S.C. \& 2000cc-I(a) (2000).

32 Cutter v. Wilkinson, 544 U.S. 709,724 (2005) (quoting Amos, 483 U.S. at 338 , and Madison v. Riter, 355 F.3d 31 0, 318 (4th Cir. 2003)).

33 Tex. Monthly, Inc. v. Bullock, 489 U.S. I, I8, 18 n.8 (1989).

34 Id. at 25.

35 Estate of Thornton v. Caldor, Inc., 472 U.S. 703, 703-04 ( 1985 ). 
pass muster. Such exemptions confer no direct monetary benefit as did the sales tax exemption in Bullock.

Further, unlike the statute entitling employees not to work on their Sabbath, an exemption from an antidiscrimination law confers no material benefit on religion since these laws generally allow conduct based on economic considerations. ${ }^{36}$ Indeed, discrimination generally injures the discriminator economically because it entails, for example, not hiring the best-qualified applicant for a job. Antidiscrimination laws do bar some economically motivated discrimination, like employment discrimination intended to cater to the biases of the employer's customers or clients. However, non-profit religious organizations do not seek profit, and the material benefit to religious organizations from exemption from antidiscrimination laws is minor, certainly smaller than the financial benefit of tax exemptions for religious organizations, which the Court has upheld, ${ }^{37}$ so religious exemptions from gay antidiscrimination laws should be valid.

\section{Freedom of Expression and Association.-In Hurley v. Irish-American Gay,} Lesbian and Bisexual Group of Boston, ${ }^{38}$ the South Boston Allied War Veterans Council organized an annual St. Patrick's Day parade. The Supreme Court sustained the Council's challenge to a Massachusetts law that forbade it to exclude a homosexual organization from marching in the parade. First, the Court held that parades are "a form of expression, not just motion."

Compelling the inclusion of a homosexual group would distort the parade's message, even though that message was not clearly and precisely stated. The Court likened the Council to a composer who may choose "the expressive units of the parade from potential participants, and though the score may not produce a particularized message, each contingent's expression in the Council's eyes comports with what merits celebration on that day." 40

In Boy Scouts of America v. Dale, the Boy Scouts of America ("BSA") were ordered to admit Dale as an assistant scoutmaster under a state law forbidding discrimination on the basis of, inter alia, sexual orientation in

36 Title VII of the Civil Rights Act, 42 U.S.C. $\$ 2000 e-2(\mathrm{e})(1)$ (2000), specifically allows employers to discriminate "in those certain circumstances where religion, sex, or national origin is a bona fide occupational qualification reasonably necessary to the normal operation of that particular business or enterprise ...." Further, an employer may use practices that have a "disparate impact" on a protected group if "the challenged practice is job related for the position in question and consistent with business necessity ...." 42 U.S.C. $\$ 2000 \mathrm{e}-2(\mathrm{k})(\mathrm{I})(\mathrm{A})(\mathrm{i})$ (2000).

37 Walz v. Tax Comm'n, 397 U.S. 664, 680 ( 1970 ).

38 Hurley v. Irish-American Gay, Lesbian and Bisexual Group of Boston, 5 I 5 U.S. 557, 557 (1995).

$39 \mathrm{Id}$. at 568 .

40 Id. at 574 .

4I Boy Scouts of Am. v. Dale, 530 U.S. 640 (2000). 
places of public accommodation. The United States Supreme Court reversed. First, the Court reviewed the BSA's mission " $[t]$ instill values in young people." ${ }^{22}$ It concluded: "It seems indisputable that an association that seeks to transmit such a system of values engages in expressive activity." ${ }^{43}$ The Court found that the BSA sincerely believed homosexual conduct violates Scout values and that requiring the BSA to accept Dale would significantly impair its message.

The Court in Dale eschewed the intermediate standard of review of United States $v$. O'Brien; ${ }^{45}$ that standard applies when "a governmental regulation ... has only an incidental effect on protected speech ...," Instead, the Court employed "traditional First Amendment analysis," sumably invokes a compelling interest standard. ${ }^{48}$ Here, "[r]he state interests embodied in New Jersey's public accommodations law do not justify such a severe intrusion on the [Boy Scouts' rights to] freedom of expressive association." ${ }^{49}$ The Court noted that it had upheld state laws that bar the exclusion of women in public accommodations, but only where "enforcement of these statutes would not materially interfere with the ideas that the organization sought to express."

3. The Establishment Clause.-Lemon v. Kurtzman held that a government act violates the Establishment Clause if it has the primary purpose or effect of advancing or inhibiting religion. ${ }^{51}$ Under Lemon, the Supreme Court has often barred acts it found to have the purpose or effect of promoting religion, but neither it nor the lower courts have ever invoked it to strike

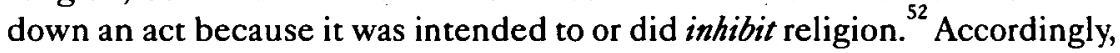
the Establishment Clause seems for now to offer little, if any, protection for religious freedom.

42 Id. at 649 .

$43 \mathrm{Id}$. at 650 .

44 Id. at 653-56.

45 United States v. O'Brien, 39I U.S. 367 (1968) (the Court upheld a law banning the burning of draft cards against a claim that the ban violated free speech).

46 Dale, 530 U.S. at 659.

47 Id. The Court used this phrase to refer to its holding in Hurley, but then said "the analysis we applied there is similar to the analysis we apply here." Id.

48 In Dale, the Court said a judge must consider whether the regulations "serve compelling state interests ... that cannot be achieved through means significantly less restrictive of associational freedoms." $1 d$. at 680 (quoting Roberts v. U.S. Jaycees, 468 U.S. 609, 623 (1984)).

$49 \mathrm{Id}$. at 642.

50 Id. at 657 (distinguishing Bd. of Dirs. of Rotary Int'l v. Rotary Club of Duarte, 48I U.S. 537 (1987), and Roberts, 468 U.S. 609).

51 Lemon v. Kurtzman, 403 U.S. 602, 612 (1971).

52 See infra notes $375-403$ and accompanying text. 


\section{B. Federal Statutes}

Title VII of the Civil Rights Act of 1964 forbids discrimination based on an employee's "race, color, religion, sex or national origin." Although it does not outlaw discrimination based on sexual orientation, it has three features relevant to religious freedom. First, it does not "apply . . . to a religious corporation, association, educational institution, or society with respect to the employment of individuals of a particular religion to perform work connected with the carrying on ... of its activities" (the "religious work" exception). ${ }^{54}$ Second, case law in most federal circuits allow churches to discriminate in the employment of ministers.

Title VII does not define "religious corporation," and courts have construed the term narrowly. The Salvation Army was held to be a religious corporation, ${ }^{56}$ but even charitable corporations with a church affiliation and an overt religious mission do not necessarily qualify. United Methodist Children's Homes of Virginia, Inc. originally qualified. However, a court found that the home had changed over time to the point where "the dayto-day life for the children at the Home ... is practically devoid of religious content or training, as such" ${ }^{57}$ and was no longer a religious corporation for purposes of Title VII. Nothing in the statute or case law says a for-profit corporation can not be a "religious corporation," 58 but every reported claim of that status by a for-profit corporation has been denied.

Third, Title VII permits discrimination on otherwise forbidden grounds for a bona fide occupational qualification ("BFOQ"). ${ }^{60}$ This provision, too, is sometimes narrowly interpreted. For instance, the Ninth Circuit denied this exception to a non-profit school that hired only Protestant teachers; it

5342 U.S.C. $\$ 2000 e-2(a)$ (2000).

54 Id. $\S 2000 \mathrm{e}-\mathrm{I}(\mathrm{a})$.

55 See, e.g., EEOC v. Roman Catholic Diocese, 213 F.3d 795, 801 (4th Cir. 2000) ("The exception precludes any inquiry whatsoever into the reasons behind a church's ministerial employment decision.").

56 McClure v. Salvation Army, 460 F.2d 553 (5th Cir.), cert. denied, 409 U.S. 896 (1972); see also Hall v. Baptist Mem'l Health Care Corp., 27 F. Supp 2d ro29, 1036-37 (W.D. Tenn. 1998), aff'd, 215 F.3 618 (6th Cir. 2000) (finding that a college of health sciences was "religious" for purposes of Title VII).

57 Fike v. United Methodist Children's Home, 547 F. Supp. 286, 290 (E.D. Va. 1982), aff' $d, 709$ F.2d 284 (4th Cir. 1983).

58 See Andrew C. Nichols, Exemptions for "Religious Corporations" from Employment Discrimination Statutes: Should Non-Profit Status Be Required?, 3 Geo. J.L. \& Pub. PoL'y 133, 137 (2005) ("No court has held that [the statute] is off-limits to for-profit corporations.").

59 See EEOC v. Townley Eng'g \& Mfg. Co., 859 F.2d 610, 619 (9th Cir. 1988); EEOC v. Preferred Mgmt. Corp., 216 F. Supp 2d 763 (S.D. Ind. 2002); Nichols, supra note 58, at $134 \mathrm{n}$. 2 ("Federal courts consistently have allowed only non-profit corporations to avail themselves of this provision, even though some for-profit enterprises ... seem substantially more religious than their non-profit counterparts.").

6042 U.S.C. $\S 2000 e-2(e)(1)(2000)$. 
held that the "religious work" exception applied only to teachers of religion classes. ${ }^{61}$ Although Title VII does not bar discrimination based on sexual orientation, these constructions may be significant because many state antidiscrimination laws do bar such discrimination and have exceptions for BFOQs ${ }^{62}$ and judicial interpretations of these laws may be influenced by Title VII cases.

Fourth, the prohibition on religious discrimination can also come into play if an employee is ordered to behave toward homosexuals or homosexuality in a way incompatible with her religion. In that case, the employer must accommodate the employee unless accommodation would cause an "undue hardship" for the employer. ${ }^{63}$ However, "to bear more than a de minimis cost ... is an undue hardship," at least where it "would involve unequal treatment of employees." ${ }^{64}$ This standard leaves little protection for employees in the duty to accommodate. ${ }^{65}$ As a policy matter, all three of these provisions of Title VII are too narrow; they allow too little religious freedom.

\section{State Constitutions}

Most state constitutions have free exercise clauses that track the federal constitution. Courts are not bound by Employment Division v. Smith when interpreting state constitutions, and some state courts adopt a broader definition of free exercise than Smith's. ${ }^{67}$ A few states have differently worded constitutional clauses that have been construed to grant broader religious freedom.

61 EEOC v. Kamehameha Sch., 990 F.2d 458, 466 (9th Cir. 1990). But see Little v. Wuerl, 929 F.2d 944 (3d Cir. 1991) (allowing Catholic school to discharge teacher who remarried without following proper canonical process); Pime v. Loyola Univ., 803 F.2d 35 I (7th Cir. 1986) (allowing Jesuit university to reserve four positions in its philosophy department for Jesuits because of the school's "tradition" and because most of its students were Catholic).

62 See Nichols, supra note 58 , at 135 nn. I4-I 7 .

63 "The term 'religion' includes all aspects of religious observance and practice, as well as belief, unless an employer demonstrates that he is unable to reasonably accommodate to an employee's or prospective employee's religious observance or practice without undue hardship on the conduct of the employer's business." 42 U.S.C. $\$ 2000 e(j)$ (2000).

64 Trans World Airlines, Inc. v. Hardison, 432 U.S. 63, 84 (1997).

65 See, e.g. Bruff v. N. Miss. Health Servs., Inc., 534 U.S. 952 (2001), discussed infra at notes $48 \mathrm{I}-83$ and accompanying text. See generally Karen Engle, The Persistence of Neutrality: The Failure of the Religious Accommodation Provision to Redeem Title VII, 76 TEx. L. Rev. 312 , 392-406 ( 1997 ) (survey of cases finding that courts require little of employers to accommodate employees' religious exercise).

66 See infra notes 498-50I and accompanying text.

67 See, e.g., Donahue v. Fair Employment \& Housing Comm'n, 2 Cal. Rptr. 2d 32, 44 (Cal. Cr. App. 1991), reviewe dismissed, cause remanded by 859 P.2d 67 I (2d Cir. 1993).

68 See, e.g., Attorney Gen. v. DeSilets, 636 N.E.2d 233 (Mass. 1994) (applying "compelling governmental interest" and "least restrictive means" text to free exercise claims under 


\section{State Statutes}

Despite the demise of the federal Religious Freedom Restoration Act, ${ }^{69}$ some states have valid RFRAs ${ }^{70}$ that may expand religious freedom. To date there are few decided cases under these laws, none involving the conflict between the gay movement and religious freedom, so their signifcance to that conflict remains unclear.

\section{Government Action Supporting Homosexuality}

\section{A. Laws Governing Private Employers and Service Providers}

1. Discrimination Based on Homosexuality.-No federal law bars discrimination against homosexuals in employment, ${ }^{72}$ although "gender stereotyping" and same-sex sexual harassment ${ }^{74}$ may constitute discrimination on account of sex in violation of Title VII. ${ }^{75}$ Most states follow the employ-

state constitution); Humphrey v. Lane, 728 N.E.2d 1039 (Ohio 2000) (semble); State v. Miller, 549 N.W.2d 235 (Wis. 1996) (semble); see also Cooper v. French, 460 N.W.2d 2, 8-9 (Minn. 1990) (stating that the Minnesota Constitution places "a more stringent burden on the state" and affords "far more protection of religious freedom than the broad language of the United States Constitution"); First Covenant Church v. City of Seattle, 840 P.2d I 74 , I 86 (Wash. 1992) (en banc) ("Our state constitutional and common law history support a broader reading of [free exercise] than of the First Amendment.").

69 See supra note $2 \mathrm{I}$ and accompanying text.

70 See 63 AM. Jur. 3D, Proof of Facts 195 nn.I-1 5 (2006) (listing state statutes).

7 I See generally Brian L. Porto, Annotation, Validity, Construction, and Operation of State Religious Freedom Restoration Acts, I 16 A.L.R.5th 233 (2004).

72 Title VII of the Civil Rights Act of 1964 does not apply to discrimination based on homosexuality. See Io EmpLoyment Discrimination § $168.10[1]$ n.I (Matthew Bender 2005). Neither does 42 U.S.C. § 1981 . See id. § $168.10[1]$ nn. 23-24; Blum v. Gulf Oil Corp., 597 F.2d 936 (5th Cir. 1979). The Americans With Disabilities Act (ADA) specifically excludes homosexuality from protected condition status. ADA $\$ 5$ I I(a), 42 U.S.C. $\$ 12211$ (a) (2000).

73 See Price Waterhouse v. Hopkins, 490 U.S. 228 (1989); 10 Employment Discrimination $\S \mathrm{I} 68.10[\mathrm{I}] \mathrm{nn} .4-14$ (Matthew Bender 2005). "Gender stereotyping" is "discrimination inficted because a person does not meet an individual or group notion of what a person of that gender should act and look like ...." Id. \$ I68.10[1]. However, employees cannot prevail with "sexual orientation ... allegations masquerading as gender stereotyping claims." Id.

74 Oncale v. Sundowner Offshore Servs., Inc., 523 U.S. 75 (1998).

75 Some other possibilities are suggested by Beall v. London City School District Board of Education, No. 2:04-cv-290, 2006 U.S.Dist. LEXIS 37657 (S.D. Ohio. June 8, 2006), where a lesbian public school teacher whose contract was not renewed sued under 42 U.S.C. $\$ 1983$. Defendant moved for summary judgment, which was granted in part but denied on two of the claims. First, the court said there was an issue of fact whether defendant had a rational basis for non-renewal. However, defendant apparently did not claim that plaintiff's homosexuality was a rational basis; indeed, defendant denied that that was its motive. The court did not address the issue because defendant declined to raise it. The court also denied summary judgment on plaintiff's claim that defendant had violated her academic freedom, but that claim does not implicate her sexuality. 
ment "at will" doctrine which is often said to allow private employers to fire or refuse to hire an employee for any reason or for no reason at all. ${ }^{76}$ The statement is misleading, though, because the rule is subject to several exceptions. First, an employer may agree by contract not to fire employees except for certain reasons." Moreover, contractual agreements can be implied in fact and may be "objectively" construed to mean something the employer never intended.

An employer who does not want to employ homosexuals should avoid vague promises, such as not to fire employees who are "doing a good job." An employer may also tell employees expressly that it considers homosexual conduct immoral and grounds for dismissal. The statement should refer specifically to homosexual conduct; a general reference, as to immoral conduct, may be deemed too vague. ${ }^{79}$ As with all employment policies, it is wise to have employees sign an acknowledgment that they have read and understood this rule. ${ }^{80}$ The employer should also avoid contradictory action that could invite a claim of estoppel or waiver. This could happen if, for example, the employer hires or retains an employee despite knowledge that she or he is an active homosexual. ${ }^{81}$

Second, some states and many local governments have laws forbidding employment discrimination based on sexual orientation. ${ }^{82}$ Most of these laws have exceptions for religious institutions and religious "practices" or "exercises," most employees. Third, despite the "any reason" principle, most states subject the at-will doctrine to a public policy exception that varies by state. A court may find that some condition or behavior has become sufficiently recognized as deserving legal protection that it has become a public policy of the state to forbid employment discrimination based on that condition

76 See, e.g., Valentzas v. Colgate-Palmolive Co., 536 A.2d 237 (N.J. 1988); Phung v. Waste Mgmt., Inc., 49I N.E.2d I I1 4 (Ohio 1986). The only state that does not follow the "at will" doctrine is Montana, which has a law providing that, after a probationary period, an employee cannot be fired except for "good cause." MONT. CODE ANN. § 39-2-904(I)(b) (2005).

77 See io Labor and Employment Law $\$ 259.03$ (Matthew Bender 2005).

78 See id. at $\$ 259.03[2]$.

79 See Burton v. Cascade Sch. Dist. Union High Sch., 512 F.2d 854 (9th Cir. 1975) (holding that law allowing teachers to be fired for "immorality" was unconstitutionally vague).

80 See Progress Printing Co. v. Nichols, 42 I S.E.2d 428, 43 I (Va. 1992) (signed acknowledgment that employment was at will held to override allegedly contradictory provision in employee handbook).

81 See Ronnie Cohen, et al., Employment Discrimination Based on Sexual Orientation: The American, Canadian and U.K. Responses, 17 LAW \& INEQ. I, 33 (1999).

82 See io Employment Discrimination \$ 168. I [ [1], n.I (Matthew Bender 2005).

83 See Egan v. Hamline United Methodist Church, 679 N.W.2d 350 (Minn. Ct. App. 2004) (suit by church music director fired for homosexuality dismissed because state ban on sexual orientation discrimination in employment excluded religious institutions). Some states do not exempt religious institutions. See, e.g., MD. CoDE art. 49B, \& 16(g)(3) (2005); Mass. Gen. Laws ANN. ch. 15 I B, \& 4, subd. 18 (2006). 
or behavior. ${ }^{84} \mathrm{~A}$ few courts have found such a policy for sexual orientation; ${ }^{85}$ most have not.

Fourth, some states forbid any firing of an employee that intentionally and unjustifiably inflicts emotional distress. ${ }^{87}$ Generally, the employee must show that termination was "accompanied by serious unlawful harassment that goes beyond the pale of what may reasonably be expected in the workplace." all bounds of human decency" and that "no reasonable person could be expected to endure." ${ }^{89}$ Finally, in some states disclosure of an employee's sexual activity violates the employee's right to privacy.

Many people have long believed that homosexuality is sinful, perverse, or psychologically disordered. Accordingly, statements to this effect should not constiture intentional infliction of emotional distress. However, it has become common to treat any disapproval of homosexuality as unbearably offensive. ${ }^{91}$ Even statements intended to help the employee, such as suggesting corrective therapy, may be deemed abusive. ${ }^{92}$ Further, an employee fired for homosexual acts can lie about oral statements by the employer. Accordingly, it may be wise for the employer to give the employee a written explanation and to record any verbal exchange.

In addition to restrictions on discharge of employees for homosexual conduct, in some cases employers are required to give the same benefits to homosexual employees with a "partner" as to an employee with a spouse.

84 See 10 Labor and Employment Law \$ 259.05[I] (Matchew Bender 2005). "The sources of public policy that are deemed important enough to support a wrongful discharge cause of action ... vary from state to state." Id.

85 See Leibert v. Transworld Systems, Inc., 39 Cal. Rptr. 2d 65, 70-73 (Ct. App. 1995); Das v. Ohio State Univ., I 5 F. Supp.2d 885, 892 (S.D. Ohio 2000) (dictum; suit dismissed because plaintiff failed to prove sexual orientation discrimination), aff'd, 57 Fed. App'x 675 (6th Cir. 2003).

86 See White v. Martin, 23 F. Supp. 2d 203, 207 (D. Conn. 1998) (applying Connecticut law), aff' $d$, 198 F.3d 235 (2d Cir. 1999); Hicks v. Arthur, 843 F. Supp. 949, 957 (E.D. Pa. 1994); Greenwood v. Taft, Stettinius \& Hollister, 663 N.E.2d 1030, 1034 (Ohio Ct. App. 1995), cert. denied, 662 N.E.2d 22 (Ohio 1996).

87 Io Labor and Employment Law \$ 259.05[3] (Matthew Bender 2005).

88 Id.

89 Id.

90 See Borquez v. Oser, 923 P.2d I66, 173 (Colo. Ct. App. 1995), aff'd in part and rev'd in part, 940 P.2d 371 (Colo. 1997); Greenwood, 663 N.E. 2d 1030; Cohen, supra note 81, at 39-41. Tortious invasion of privacy could also occur when "intrusive, unreasonable methods are used to obtain" information about an employee's sexual conduct. Id. at $4 \mathrm{I}$.

91 See supra notes 8-12 and accompanying text.

92 See infra notes 373-74 and accompanying text.

93 See io Employment Discrimination § i68. 1 [ [4] (Matthew Bender 2005). 
2. Does Discrimination Based on Homosexuality Constitute Religious or Sex Discrimination?-In Hall v. Baptist Memorial Healthcare Corp. and Pedreira v. Kentucky Baptist Homes for Children, Inc. ${ }^{95}$ employees were fired for homosexual conduct. These employees claimed religious discrimination in violation of Title VII of the Civil Rights Act because they were compelled to accept a particular religious view of homosexuality. In Hall, the plaintiff tried to buttress this claim by becoming a lay minister with a church that condoned homosexuality and then claiming that her discharge stemmed from membership in this church and therefore violated Title VII.

Both cases rejected the claim. In Hall, the court said the plaintiff "must show that it was the religious aspect of her leadership position that motivated her employer's actions .... The fact that the organization in which she assumed a leadership position is a church does not transform her dismissal into one based on religion." ${ }^{96}$ Hall was fired because of her "leadership position in an organization that condones a lifestyle the College considers antithetical to its mission." 97 That the organization was a church was merely coincidental. Similarly, in Pedreira the employer was fired because of her conduct, not because of her "beliefs themselves." ${ }^{98}$ Thus, her firing did not violate Title VII.

These decisions are clearly correct. All employers impose some behavioral restrictions on employees. It would result in a farce if an employee could gain a right to engage in any behavior merely by declaring a religious belief in the propriety of that behavior. Of course, an employer might impose a prohibition on employee conduct that is facially religion-neutral but in practice serves no purpose other than religious discrimination. An employer might, for instance, forbid employees to eat pork solely to exclude Jews and Muslims. In Hall and Pedreira, though, the restriction was clearly not a sham or pretext.

In Dorrv. First Kentucky National Corp., ${ }^{99}$ the employee told his employer that he was a homosexual and active in a church-related group that promoted homosexual rights. He was told that to keep his job he must quit the group. The court upheld the employee's claim of religious discrimination under Title VII. Unlike the employers in Hall and Pedreira, the employer in Dorr did not claim to have a religious mission. Further, the defendant acted on the basis of the employee's activity in a religious group, not his sexual conduct. ${ }^{100}$ Presumably, then, the employer's motive was concern

94 Hall v. Baptist Mem'l Health Care Corp., 215 F.3d 6I8 (6th Cir. 2000).

95 Pedreira v. Ky. Baptist Homes for Children, Inc:, I86 F. Supp.2d 757 (W.D. Ky. 200I).

$96 \mathrm{Hall}, 2 \mathrm{I} 5 \mathrm{~F} .3 \mathrm{~d}$ at 627.

$97 \mathrm{ld}$.

98 Pedreira, 186 F. Supp.2d at 761.

99 Dorr v. First Ky. Nat'l Corp., 796 F.2d I 79 (6th Cir.), withdrawn by publisher, reh'g granted, en banc, No. 84-5067, I986 U.S. App. LEXIS 33065 (6th Cir. Oct. 10, 1986).

Ioo Id. 
about the financial repercussions of defendant's church-related activity, not a religious or moral objection to his sexual conduct.

It has been argued that sexual orientation discrimination constitutes sex discrimination. ${ }^{101}$ This argument has been rejected in the context of employment discrimination.

3. Private Service and Housing Providers.-Some laws forbid discrimination on the basis of sexual orientation in the commercial provision of services. In North Coast Women's Care Medical Group, Inc. v. Superior Court of San Diego County, ${ }^{103}$ doctors refused on religious grounds to inseminate the plaintiff, a lesbian who had a registered domestic partner. The plaintiff sued under a state statute that prohibits discrimination based on sexual orientation. The court held that defendants were entitled to a trial on their defense that they had not discriminated because plaintiff was a lesbian; they would not inseminate any unmarried woman. However, the court noted that the legislature had later amended the statute to forbid discrimination based on marital status. Accordingly, doctors are now required to inseminate any woman, married or single, heterosexual or homosexual. ${ }^{104}$

The case for religious freedom here is even stronger than it is for employment by private businesses. Employment of homosexuals does not directly condone homosexuality, which is why most traditional faiths eschew employment discrimination against homosexuals. Medical care is a personal service, which the law often treats differently from other commercial transactions. ${ }^{105}$ It may entail commission of what the provider considers a grave sin; that is why medical workers are not required to perform abortions.

Io I Baehr v. Lewin, 852 P.2d 44, 60-63 (Haw. I993), overruled by constitutional amendment, Haw. Const. art. I, § 23; Andrew Koppelman, Why Discrimination Against Lesbians and Gay Men Is Sex Discrimination, 69 N.Y.U. L. Rev. 197 (1994); Samuel A. Marcosson, Harassment on the Basis of Sexual Orientation: A Claim of Sex Discrimination Under Title VII, 8I Geo. L.J. I, 5, 8 (1992).

102 See Williamson v. A.G. Edwards and Sons, Inc., 876 F.2d 69, 70 (8th Cir. 1989); DeSantis v. Pac. Tel. \& Tel. Co., 608 F.2d 327, 330-31 (9th Cir. 1979); Smith v. Liberty Mut. Ins. Co., 569 F.2d 325, 326-27 (5th Cir. 1978).

Io3 N. Coast Women's Care Med. Group, Inc. v. Superior Court of San Diego County, 40 Cal. Rptr. 3 d 636 (Ct. App. 2006).

104 Id. at $647-48$.

I05 "A court of equity generally will not order specific performance of a personal service contract." Howard O. Hunter, Modern Law of Contracts § 13.17 (2004). "A promise to render personal service will not be specifically enforced." Restatement Second of Contracts $\S 367(\mathrm{I})$ ( $198 \mathrm{I})$.

I06 See 42 U.S.C. $\$ 300 a-7$ (2000) (forbidding recipients of federal medical care funds to discriminate against anyone who performs or refuses to perform sterilizations or abortions); Am. Med. Ass'N Code of Med. Ethics § E-9. 12 ("Generally, both the physician and the patient are free to enter into or decline the relationship."). 
Medical workers do not have unfettered discretion; they may not, for instance, refuse treatment because of the patient's race. ${ }^{107}$ Race, though, is a special case in our society. ${ }^{108}$ Further, the Beniter case would arguably be different if the doctor refused to give the plaintiff any treatment; or if it involved an emergency in which the patient had no opportunity to go to another provider; or if it did not involve reproduction, a matter of special ethical concern.

Indeed, since the plaintiff could easily have obtained treatment elsewhere and eventually did so, this suit seems motivated by publicity rather than medical need; the goal seems to be to discredit and silence religious disapproval of homosexuality. This inference is supported by the fact that plaintiff is represented by Lambda Legal Defense and Education Fund, which devotes much of its efforts to publicity promoting homosexuality. In a sense, defendant has already lost since she is forced to argue that her refusal was based on plaintiff's marital status, not her sexual orientation. The interest in sexual orientation should not override religious freedom.

The Arlington (Virginia) Human Rights Commission has ordered Bono Film and Video to duplicate pro-homosexual videos presented by lesbian activist Lilli Vincenz. The company has contested the order, claiming a right not to process material that is obscene, could embarrass employees, hurt the company's reputation, or violates the company's Christian and ethical values, including material that promotes homosexuality. The law should concede this right. The company's refusal imposes no great burden on customers; they can easily get the requested service elsewhere. Businesses should not be required to deal with materials containing controversial sexual content. Fortunately, shortly after Bono filed his suit the Commission withdrew its complaint.

In Doe v. California Lutheran High School Association, ${ }^{111}$ the school was sued for expelling two girls involved in a lesbian relationship. The trial court denied defendant's motion to dismiss claims for violation of statutes forbidding sexual orientation discrimination against customers by business establishments, invasion of privacy, and unfair business practices, and of

107 See id. ("P]hysicians who offer their services to the public may not decline to accept patients because of race, color, religion, national origin, sexual orientation, or any other basis that would constitute invidious discrimination.").

108 See infra notes 51 3-23 and accompanying text.

log See Ellen Ann Andersen, Out of the Closets \& into the Courts: Legal Opportunity Structure and Gay Rights Litigation 37, 40, 50-55, 94, I 40, 179-80, 214-15 (2005) (documenting Lambda's publicity activities).

I 10 See Press Release, Liberty Counsel, Human Rights Commission Dismisses Complaint Against Christian Businessman After Liberty Counsel Files Suit (June I3, 2006), http://www. lc.org/pressrelease/2006/nro6 1 $306 . \mathrm{htm}$. The company denied that it discriminated against Ms. Vincenz because she is a lesbian.

I I Defendant's Motion to Strike Portions of Plaintiff's First Amended Complaint, Doe v. Cal. Lutheran High Sch. Ass'n, No. RIC 441819 (Super. Ct. Cal. Apr. 19, 2005). 
the state's constitutional right of privacy despite the court's recognition that the school is a religious corporation ${ }^{12}$ and despite plaintiffs' concession that it does not receive state assistance or enroll students who receive state financial aid. ${ }^{113}$ Evidently the case later settled, so the trial court's denial of the motion to dismiss is not an important precedent. Nonetheless, it is disturbing to think that a religious school taking no public funds could be barred from applying the tenets of its faith to its students, and even more disturbing to note that in the same state a public school student can be punished for wearing a T-shirt referring to the Bible's position of homosexuality.

In Wisconsin ex rel. Sprague v. City of Madison, defendants leased a fourbedroom house and subleased some of the rooms to others. "Petitioner Caryl Sprague sought to rent one of these rooms and inquired "whether the household would respect her sexual orientation." rent a room to Sprague and another lesbian because defendants "were not comfortable living with a person of her sexual orientation." were held to have violated a Madison ordinance banning discrimination based on "sexual orientation." 117

The court held that applying the ordinance here did not violate defendants" "right to privacy in the home or family or the right to engage in first amendment activity free of governmental intrusion." simply: "Appellants gave up their unqualified right to such constitutional protection when they rented housing for profit. The restrictions placed by the Madison City Council on persons who rent housing for profit are not unreasonable and do not encroach upon appellant's constitutional protections." 119 The absolute denial of privacy and association rights when there is any element of commercial activity is troubling. The ordinance recognized privacy concerns by permitting the limitation of rentals "to solely male or female persons if such housing ... is rented with the understanding that toilet and bath facilities must be shared with the landlord or with other tenants." ${ }^{120}$ Thus the ordinance validates some privacy desires but not others.

I 12 Id. at 3 .

113 First Amended Complaint II 17, Doe v. Cal. Lutheran High Sch. Ass'n, No. RIC 4418 Ig (Super. Ct. Cal. Feb. 3, 2006).

I 4 State ex rel. Sprague v. City of Madison, 555 N.W.2d 409 (Wis. Ct. App. 1996) (table). The unpublished opinion is reported at 1996 WL 544099.

15 Id. at 4.

116 Id. at I.

I 7 Id. at 2 (quoting Madison, Wis., Gen. Ordinances $\$ 3.23(4)(\mathrm{a})$ ( 1989)).

118 Id. at 3 .

I 9 Id.

120 Id. at 2 (quoting Madison, Wis., Gen. Ordinances $\S 3.23(4)(\mathrm{b})$ ( 1989 )). 
This was not housing offered by a large, impersonal real estate corporation; it was a four-bedroom home occupied by defendants themselves. Further, Sprague's inquiry "whether the household would respect her sexual orientation" could have given defendants concern that Sprague might cause trouble in the home if she felt that others disliked her sexual activities. The court found that this was just "a prudent inquiry about the environment in which one will live ...." This finding suggests either that defendants were legally obliged not only to rent to Sprague but also to suppress any disapproval of her sexual conduct, or at least that defendants were required to accept conflict in their home with Sprague over her sexual behavior. In these circumstances, most people would consider the defendants' privacy concerns valid.

Some housing antidiscrimination laws exempt small complexes or units within the owner's own home. ${ }^{122}$ A few courts have recognized a further free exercise or hybrid exemption from these laws, but most have not.

\section{Business Entities as Expressive or Religious Organizations.-Many people} want to maintain their religion at work in a for-profit business. ${ }^{124}$ Many business firms have an overt religious commitment that influences their hiring and conduct of the workplace. So far, however, legislators have denied these firms exemption from laws that would compel them to violate their faith. Courts have also refused an exemption under federal and state constitutional provisions for free exercise. These cases do not involve discrimination based on sexual orientation, but presumably they also cover such discrimination where it is illegal.

In State v. Sports \& Health Club, Inc., ${ }^{125}$ the corporation operated several fitness centers. It asked job applicants about their religion and marital status and refused to employ "individuals living with but not married to a person of the opposite sex." ${ }^{126}$ The state charged the company under a law barring employment discrimination based on, inter alia, religion or marital

121 Id. at 4.

122 See Jack M. Battaglia, Religion, Sexual Orientation, and Self-Realization: First Amendment Principles and Anti-Discrimination Laws, 76 U. DeT. MERCY L. Rev. I 89, 229 nn. I 84-86 (I 999 ).

123 Recognizing an exemption: Thomas v. Anchorage Equal Rights Comm'n, 165 F.3d 692 (9th Cir. 1999), rev'd on procedural grounds, 220 F.3d I I34 (9th Cir. 2000) (en banc); Cooper v. French, 460 N.W.2d 2, 9-10 (Minn. 1990). Denying an exemption: Swanner v. Anchorage Equal Rights Comm'n, 874 P.2d 274 (Alaska I994) (per curiam); Smith v. Fair Employment \& Hous. Comm'n, 913 P.2d 909 (Cal. 1996), cert. denied, I 7 S. Ct. 253 I (1997). See Battaglia, supra note I 22, at 289-98; Robin C. Miller, Annotation, Landlord's Refusal to Rent to Unmarried Couple as Protected by Landlord's Religious Beliefs, Io A.L.R. 6th 5I3 (2006).

124 The desire may be growing. See Nichols, supra note 58, at 145-46 (giving anecdotal evidence).

I 25 State v. Sports \& Health Club, Inc., 370 N.W.2d 844 (Minn. 1985), appeal dismissed, 478 U.S. 1015 (1986).

126 Id. at 847 . 
status. Because the company was not a religious organization but a "business corporation engaged in business for profit" and "engaging in a secular endeavor," the law despite its application of the pre-Smith "compelling state interest" standard.

EEOC v. Preferred Management Corp., ${ }^{128}$ presented an even stronger claim for a religious exemption. The company there provided home health care. Its owners were born-again Christians who believed they had a duty to practice their faith in their work. ${ }^{129}$ To that end, they wanted to share their faith with the people they served, and wanted to hire only co-religionists who would further this mission. The firm's pervasive religious objective differentiates it from Sports \& Health Club, Inc., which did not carry a religious message to its clients. Nonetheless, the court denied the "religious corporation" exemption from Title VII. No other case has granted this exemption to a for-profit business corporation. ${ }^{130}$ These decisions are consistent with the free exercise test of Employment Division v. Smith.

Although the issue seems not to have been addressed in case law, it also seems unlikely that a for-profit business corporation would qualify as an expressive association under Hurley and Dale. However, to deny accommodation to for-profit companies with a strong religious mission is disturbing. First, that policy restricts individual freedom. Of course, every law barring private discrimination limits freedom. Where the problem of discrimination is severe and intractable, as with race, we accept that restriction, but in most cases we do not. In particular, discrimination based on an ideological commitment is perfectly legal. An environmental protection organization can discriminate by hiring only environmentalists, and a civil liberties organization can hire only people committed to free speech. ${ }^{131}$ It seems consistent that an organization with a religious commitment should be allowed to hire only people who share that commitment. In both cases the discrimination is a bona fide occupational qualification. This allowance does not discriminate against atheists since an organization could have a mission to advance atheism.

Prohibiting religious employment requirements does expand the job options of workers who do not meet those requirements, but the benefit to them is small. Neither Health \& Sports Club, Inc. nor Preferred Management Corp. dominated its local market; workers they rejected had alternatives in the same field and locale. Further, the small benefit of the prohibition to these workers comes at substantial cost to others; forbidding

127 Id. at 853 .

128 EEOC v. Preferred Mgmt. Corp., 216 F. Supp.2d 763 (S.D. Ind. 2002).

$129 \mathrm{Id}$. at $772-73$.

130 See supra notes $124-27$ and accompanying text.

13 I See 3 Labor and Employment Law \$57.02 (Matthew Bender 2005). 
business corporations to adhere to a religious commitment denies millions of Americans their wish to practice their faith at work.

Because of Title VII, companies that allow employees to practice a particular faith may face problems. Special treatment of one faith may trigger demands for equal treatment for other faiths and atheism. Accommodating these demands could be unbearably costly. Also, religious practice often requires group activity. For instance, for Jews, prayer takes on a different character when a minyan (a group of ten or more adult men) is present. Few companies could regularly convene a minyan unless they could discriminate in hiring. Finally, faith often requires shunning improper behavior by others. The faithful may be enjoined to avoid others who dress immoderately or speak profanely. To accommodate such practice requires imposing rules on all employees, which would at least generate conflict and might itself violate antidiscrimination laws.

Although the Founders refrained from the establishment of religion, by the Free Exercise Clause, they acknowledged the unique importance of religious practice. As Kent Greenawalt says, "people should not lose their capacity to carry out a religious vision simply because they want to do so in commercial affairs." ${ }^{132}$ Thomas Berg adds, "[t]he very existence of the religious discrimination provisions in Title VII ... reflects our legal tradition's judgment that citizens legitimately carry their religious beliefs into the commercial marketplace and should be protected in doing so." ${ }^{133}$ The denial of an exemption from antidiscrimination laws for religiously committed business firms elevates the pecuniary interests of one group over the freedom of conscience of another group. That is not a policy we should endorse.

Allowing businesses to discriminate on the basis of a religious commitment creates little incentive to feign such a commitment because discrimination is costly; it means rejecting the best person for a job. A company might accept that cost to satisfy a personal taste and use religious commitment as a pretext, but to sustain the burden of proving a religious commitment adds further cost. A company would have to show substantial evidence of a commitment "to integrate religion into all aspects of the business," ${ }^{135}$ including its hiring practices and management of the workplace. The cost of doing all this as a pretext is so high that few would bear it. Although there should be no size limit for corporations that claim religious status, large firms are less likely to meet this test. Also, the larger the corporation, the more likely

I 32 Kent Greenawalt, Title VII and Religious Liberty, 33 Loy. U. CHI. L.J. I, 37 (200 I).

133 Thomas C. Berg, Religious Speech in the Workplace: Harassment or Protected Speech?, 22 Harv. J.L. \& Pub. Pol'y 959, 964 (1999).

134 The case for an exemption is persuasively argued in Berg, supra note 133; Julie Manning Magid \& Jamie Darin Prenkert, The Religious and Associational Freedoms of Business Ozoners, 7 U. PA. J. LAB. \& EMP. L. I9I (2005); Nichols, supra note 58.

I 35 Berg, supra note 133 , at 1003. 
that those excluded by it would have difficulty finding equivalent alternative employment, which should further tilt analysis against an exemption. Likewise, although there should be no limit on the type of business done by a religious corporation, the weaker the connection of the business to religion, the less likely that it has a pervasive commitment to religion.

\section{B. Government Employment}

1. Discrimination Against Homosexuals.-A claim by a government employee of having been illegally discriminated against because of his homosexuality should never clash with religious freedom because the government employer has no right to exercise religion at all; by virtue of the Establishment Clause, the government must be religiously neutral. Such claims still deserve brief discussion here because such discrimination could raise questions about the legal relevance of objections to homosexuality among fellow employees or the public and because the legal standards for government employment may sometimes be relevant to private employment.

In 1990 Michael Bowers, the attorney general of Georgia, offered Robin Joy Shahar a job as staff attorney to begin after she graduated from law school; she accepted. ${ }^{136}$ In 1991 Shahar "married" another woman. When the attorney general learned of this, he rescinded the job offer. Shahar sued. The district court granted the attorney general summary judgment, and the Court of Appeals affirmed. ${ }^{137}$

The court "assume[d], for argument's sake, that either the right to intimate association or the right to expressive association or both are present." ${ }^{138}$ It ruled that for government employees these rights do not invoke strict scrutiny but the Pickering test: "to arrive at a balance between the interests of the [employee], as a citizen, in commenting upon matters of public concern and the interest of the State, as an employer, in promoting the efficiency of the public services it performs through its employees." ${ }^{139}$ In Elrod v. Burns, the Court held that this right does not extend to "policymaking" positions. ${ }^{140}$ However, in Rankin v. McPherson, the Court stressed that "vigilance is necessary to ensure that public employers do not use authority over employees to silence discourse, not because it hampers public functions but simply because superiors disagree with the content of employees' speech." ${ }^{141}$

In Shahar the court did not invoke the Elrod standard for policymaking positions. However, it did say that "the government employer's interest

\footnotetext{
I 36 Shahar v. Bowers, I 14 F.3d 1097, I roo (I Ith Cir. 1997).

137 Id. at 1099 .

138 Id. at 1102.

I39 Pickering v. Bd. of Educ., 391 U.S. 563, 568 (1968).

I 40 Elrod v. Burns, 427 U.S. 347,367 (1976).

141 Rankin v. McPherson, 483 U.S. 378,384 ( 1987 ).
} 
in staffing its offices with persons the employer fully trusts is given great weight when the pertinent employee helps make policy, handles confidential information or must speak or act-for others to see-on the employer's behalf." ${ }^{142}$ Such employees "are in a special class ... and might seldom prevail under the First Amendment in keeping their jobs when they are in conflict with their employers." ${ }_{144}^{143}$ The position of staff attorney here was such a position.

Finally, the court concluded that it:

cannot say that [Bowers] was unreasonable to think that Shahar's acts were likely to cause the public to be confused and to question the Law Department's credibility; to interfere with the Law Department's ability to handle certain controversial matters, including enforcing the laws against homosexual sodomy; and to endanger working relationships inside the Department. We also cannot say that the Attorney General was unreasonable to lose confidence in Shahar's ability to make good judgments as a lawyer for the Law Department. ${ }^{14}$

Two points in Shahar deserve notice. First, the decision depends on its unique facts with respect both to the job in question and to Shahar's conduct. Shahar staged a widely publicized "marriage" ceremony with another woman after she accepted the job offer at a time when the status of samesex "marriage" was being hotly disputed in the courts and in public. ${ }^{146}$ She was also less than candid about this "marriage" with her prospective employer.

Second, the court relied on the fact that homosexual sodomy violated a Georgia criminal law that had been upheld by the Supreme Court in Bowers v. Hardwick. ${ }^{148}$ Shahar's "marriage" "could undermine confidence about the attorney general's commitment to enforce [this] law ... (or laws limiting marriage and marriage benefits to traditional marriages)." "i49 Bowers has now been overruled. ${ }^{150}$ Future cases will have to determine the significance of that overruling to cases like Shahar.

I42 Shahar, I 14 F.3d at $1103-04$.

143 Id. at 1103 .

$144 \mathrm{Id}$. at $\mathrm{I} 104$.

145 Id. at I I Io. In an opinion by Judge Godbold four judges dissented because they believed Bowers "did not act reasonably." Id. at I I 8 (Godbold, J., dissenting).

146 See id. at 1 104-05 (majority opinion).

I47 "Shahar misled Deputy Attorney General J. Robert Coleman into believing that she was going to marry a male." Id. at I i 6 n.9 (Tjoflat, J., concurring).

148 Bowers v. Hardwick, 478 U.S. 186 (1986), cited in Shahar, I 14 F.3d at 1105 n.1 7.

149 Shahar, I 4 F.3d at 1105 n. 17

150 Lawrence v. Texas, 539 U.S. $55^{8}$ (2003). 
2. The Religious Freedom of Government Employees.-In Pickering v. Board of Education, the Supreme Court held that in deciding the free speech rights of public employees the court must "arrive at a balance between the interests of the [government employee], as a citizen, in commenting upon matters of public concern and the interest of the State, as an employer, in promoting the efficiency of the public services it performs through its employees." "The Supreme Court has never discussed the religious freedom of government employees and whether it is subject to the Pickering test or to a higher standard of review. Several lower courts have addressed the issue.

a. Lumpkin v. Brown. ${ }^{152}$-Plaintiff Reverend Eugene Lumpkin was pastor of a Baptist church and an appointed member of the San Francisco Human Rights Commission ("HRC"). In several public statements Lumpkin affirmed his belief in the biblical tenets that homosexual acts are sins and that a man who sleeps with a man should be put to death. However, he said these norms must be viewed in the context of liberation of the Israelites from Egypt. ${ }^{153}$ When later called by the mayor, Lumpkin made clear that he did not advocate, and never had advocated, violence against gays. ${ }^{154}$ Further, he was never alleged to have discriminated against gays as a member of the HRC. Nonetheless, the mayor removed Lumpkin from the Commission. He sued, claiming violation of his freedom of expression. ${ }^{155}$

The Court of Appeals affirmed summary judgment against Lumpkin. Applying the Elrod dichotomy, the court held that Lumpkin had a policymaking position and could be removed even on the basis of political affiliation. Although this finding sufficed to dispose of the case, the court went on to apply the Pickering balancing test and found that the test weighed in favor of the City because Lumpkin had preached "homophobia" ${ }^{158}$ and his "statements explicitly condemning homosexuality as a sin and implicitly endorsing violence against homosexuals are not simply hostile to the

15I Pickering v. Bd. of Educ., 39I U.S. 563, 571-72 (1968). This standard applies only when "employees are speaking as citizens about matters of public concern." Garcetti v. Caballos, I 26 S.Ct. I95 I, 1958 (2006). When they "make statements pursuant to their official duties ... the Constitution does not insulate their communications from employer discipline." Jd. at 1960 .

152 Lumpkin v. Brown, 109 F.3d I 498 (9th Cir.), cert. denied, 522 U.S. 995 (1997). For an able discussion of Lumpkin see Steven H. Alden, A Tale of Two Ciries in the Gay Rights Kulturkampf: Are the Federal Courts Presiding Over the Cultural Balkanization of America?, 35 WAKE FOREST L. REv. 295 (2000).

153 Lumpkin, 109 F.3d at 1499 n.1.

154 See Petition for Writ of Certiorari at A-48, A-49, Lumpkin v. Brown, 522 U.S. 995 (1997) (No. 97-367).

155 Lumpkin, I09 F.3d at 1499-1500

$156 \mathrm{ld}$. at 1500 . 
Commission's charge, they are at war with it." ${ }^{157}$ Although these comments could be dismissed as dictum, they warrant fear even in non-policymaking employees that they could be fired for confessing the traditional Judeo-Christian view of homosexuality. The court seems eager to ignore the warning in Rankin that courts should not let government employers silence speech simply because they disagree with it.

b. Good News Employee Association v. Hicks.-Suppression of religious expression was also upheld in Good Newes Employee Association v. Hicks. ${ }^{158}$ Plaintiffs, two employees of the Community and Economic Development Office ("CEDA") of Oakland, California, posted in their workplace, notices about Good News Employee Association ("GNEA") to which they belonged. The flyer described GNEA as "a forum for people of Faith to express their views on contemporary issues of the day. With respect for the Natural Family, Marriage and Family values." 159

After complaints by a lesbian co-worker CEDA removed the flyers under the city's "Equal Employment Opportunity/Anti-Discrimination/NonHarassment Policy and Complaint Procedure." ${ }^{160}$ Plaintiffs were also told they could announce their group through the city's e-mail system only if they deleted "verbiage that could be offensive to gay people." An officer sent all employees a memorandum referring to "recent ... incidents" where "flyers were placed in public view which contained statements of a homophobic nature and were determined to promote sexual orientation based harassment." 162

Applying the Pickering balancing test, the court concluded that plaintiffs' interest in speaking was "slight, as the restriction placed on their speech ... was quite limited." CEDA did not limit "their speech outside of work" and let them "discuss their views with co-workers as they wish at appropriate times (at lunch, on a break)." They were also allowed to "broadcast the existence of their group, subject to certain editorial restrictions." ${ }^{163}$ The court did not enumerate these restrictions; presumably it meant the condition requiring removal of "verbiage that could be offensive to gay people." 164

157 ld.

158 Good News Employee Ass'n v. Hicks, No. C-03-3542 VRW, 2005 WL 351743 (N.D. Cal. Feb. I4, 2005)

159 Id. at * 1 .

I60 Id. at *2. Not included in the flyers was GNEA's Statement of Faith, which defined marriage as "a union between a man and a woman according to California state law" and the "Natural Family" as "a man and a woman their children by birth or adoption, or the surviving remnant thereof (including single parents)." Id. at * I.

161 Id. at*2.

162 Id. at *3.

163 ld. at ${ }^{*} 7-8$.

164 Id. at *2. 
The court conceded that "[d]efendants' countervailing interest is also modest ... . [W]orkplace disruption is the touchstone of the employer's interest in the Pickering balance." Here, a co-worker was "disturbed by the flyer ... . But whether the particular sensitivity of a single coworker amounts to a cognizable workplace disruption under Pickering is far from clear." ${ }^{165}$ Further, "the suppressed speech was not patently inflammatory 'fighting words."

Nonetheless, the court ruled in favor of the city for two reasons. "First, plaintiffs' interest in this particular channel of communication is vanishingly small .... Plaintiffs do not have a privileged First Amendment interest in communicating their message to the officemates, for their First Amendment rights derive from their status as citizens, not their status as employees." ${ }^{167}$ Second, the defendants' action "was a narrowly tailored and proportionate response to the actual workplace disruption or, perhaps better described, distraction." ${ }^{168}$ Plaintiffs objected to the employer's viewpoint discrimination, which silenced their message while leaving others free to disparage them as "homophobes." The court denied that such treatment is barred under Pickering: to entertain such complaints "would remit the disciplinary operations of public agencies to the micromanagement of the courts." 169

The court's reasoning carries some weight. The employer need not allow posting of flyers at all, so removing them did not a priori violate the First Amendment. However, if the employer permits postings, it is questionable whether it can then limit their content beyond the mere exclusion of "fighting words." Here, the words "Natural Family, Marriage and Family values" were forbidden because they were deemed "homophobic" and "were determined to promote sexual orientation based harassment." On its face, that claim seems dubious, and the employer offered no evidence to support it. Most people would not even realize that the flyer implied a message about homosexuality. The context made the flyer particularly innocuous. It was not imposed on unwilling listeners; those who so chose could ignore it. The court's concern about "micromanagement" of public agencies is understandable, but a balancing test like Pickering contemplates just that. Otherwise, government employers are free to facilitate messages on one side of a public debate while suppressing the other side.

Further, the employer's determination that plaintiffs' language was "homophobic" and would "promote sexual orientation based harassment" must raise fears among government employees about all expressions of traditional Judeo-Christian views on the family in the workplace. If the employer can ban these flyers as disruptive, presumably it can bar any ex-

I65 Id. at *8.

I66 Id. at * 9 .

167 Id.

$168 \mathrm{Id}$.

I69 Id. 
pression of such views, at least if any employee objects to them. The state may promote certain views in its own speech, but it does not follow that it should be able to suppress the personal expression of different views by its employees.

c. Downs v. Los Angeles Unified School District. ${ }^{170}$ - Here, a public school teacher wanted to post materials disapproving of homosexuality on a school bulletin board in response to materials distributed by the school district as part of its Gay and Lesbian Awareness Month. The court held that displays on the bulletin board were controlled by the school and therefore were school-sponsored speech; it was not an open forum on which members of the school community could post their own views."

In the classroom, the authority of school boards to set the curriculum generally trumps teachers' free speech rights. ${ }^{172}$ This makes some sense; what children are taught should not depend on the whim of each teacher. There must be some limit, though, on a school's power to favor one side in matters of public debate. Should a school, for instance, be able to compel teachers to tell students that abortion is homicide? The school's discretion should be even more limited for a bulletin board, which children may disregard and where messages can be labeled as expressing individual rather than official views.

d. Mississippi Commission on Judicial Performance v. Wilkerson. ${ }^{173}-$ Judge Wilkerson sent The George County Times a letter, later published, that did not identify him as a judge and that stated that homosexuals "should be put in some kind of mental institute." ${ }^{174}$ Wilkerson repeated these views when called by a radio reporter. Lambda Legal filed a complaint with the Mississippi Commission on Judicial Performance ("MCJP") who in turn charged Wilkerson with "willful misconduct in office and conduct prejudicial to the administration of justice which brings the judicial office into disrepute" and with violations of several provisions of the state Code of Judicial Conduct ("CJC"). ${ }^{175}$

The MCJP found that the statement violated a canon of the CJC, but the state Supreme Court found that this canon was not in effect when the

170 Downs v. L.A. Unified Sch. Dist., 228 F.3d 1003 (9th Cir. 2000).

I 7 I For a discussion of school-sponsored speech see infra notes 270-372 and accompanying text.

I 72 See Boring v. Buncombe County Bd. of Educ., I36 F.3d 364 (4th Cir. 1998) (en banc); Kirkland v. Northside Indep. Sch. Dist., 890 F.2d 794 (5th Cir. 1989). But see Cockrel v. Shelby County Sch. Dist., 270 F.3d 1036 (6th Cir. 2001).

I73 Miss. Comm'n on Judicial Performance v. Wilkerson, 876 So. $2 d$ I006 (Miss. 2004).

174 Id. at 1009 .

I 75 ld. at $1008-09$ 
letter was published. ${ }^{176}$ Nonetheless, the court went on to consider whether Wilkerson violated Canon 2(A) of the CJC which was in effect and which provided: "A judge should respect and comply with the law and should conduct himself at all times in a manner that promotes public confidence in the integrity and impartiality of the judiciary." 177

In interpreting this canon, the court followed Scott $v$. Flowers ${ }^{178}$ in which the United States Court of Appeals for the Fifth Circuit "recognized that the state may restrict the speech of elected judges in ways that it may not restrict the speech of other elected officials." ${ }^{179}$ However, the state may not "infringe upon the right "to make statements ... on public issues outside a campaign context" unless it can "carry a very difficult burden in order to demonstrate that its concededly legitimate interest in protecting the efficiency and impartiality of the state judicial system outweighs [the judge's] first amendment rights." 180

Here, the court said Judge Wilkerson had spoken on a matter of public concern and therefore could not be punished unless the restraint "is narrowly tailored to achieve a compelling state interest." claimed a compelling interest in maintaining the "impartiality of the judiciary," meaning "the lack of bias for or against (sic) either party to the proceeding." ${ }^{182}$ While conceding that this is a compelling state interest, the court found "no compelling state interest in requiring a partial judge to keep quiet about his prejudice so that he or she will appear impartial." ${ }^{183}$ The court conceded that Judge Wilkerson's statements cast doubt on his ability to treat homosexuals fairly and that he might have to withdraw from cases in which they are parties, but that this was a separate issue from forbidding him to air his opinions. ${ }^{184}$ Accordingly, the court dismissed the Commission's complaint against Judge Wilkerson.

Two justices dissented. They thought Judge Wilkerson's comments violated a judicial canon because his comments "cast doubt on his ability to act impartially." ${ }^{185}$ Further, the canon "plainly serves a compelling interest in promoting impartiality and the appearance of impartiality in our

176 Id. at Ioro.

177 Miss. Rules of Court, Code of Judicial Conduct Canon 2 (2006).

178 Scott v. Flowers, 910 F.2d 20 I (5th Cir. 1990).

$179 \mathrm{Id}$. at 212.

180 Id. (quoting Morial v. Judiciary Comm'n of La., 565 F.2d 295, 301 (5th Cir. 1977) (emphasis added)). The court also followed In re Sanders, 955 P.2d 369, 375 (Wash. 1998), in which the court upheld the right of a judge to make a speech at a pro-life rally. Wilkerson, 876 So. $2 \mathrm{~d}$ at $10 \mathrm{r} 3$.

I 81 Wilkerson, 876 So. $2 \mathrm{~d}$ at $10 \mathrm{I} 3$ (internal quotes omitted).

182 Id. at 1015 .

183 Id.

184 Id. at 1or 5-16.

185 Id. at 102 I (Carlson, J., dissenting). 
courts." ${ }^{186}$ The judge had a right under the canons to "express his views on statutes concerning same-sex partners and legislation regulating their activities or their rights," but that when he said homosexuals "were sick and that they all needed to be indiscriminately placed in mental institutions, he crossed over the line!"187

On the First Amendment issue, the dissent found Scott v. Flowers distinguishable because Judge Wilkerson did not hide his views on his opinions of the homosexual population as a whole.

I do not agree that this type of speech-the judge's personal views regarding all homosexuals-relates to political and social community concerns. However, even if the judge's speech is found to relate to political and social community concerns, this type of speech fails the second prong [of Scott] by "impeding the performance of the speaker's duties." 188

Judge Wilkerson's comments failed the second prong, in the dissenters' view, by "clearly and convincingly leading the public to conclude that he entertains a bias against an entire class of individuals and precipitating a reasonable fear that their pleas, arguments, and testimony before his court will not be considered with the impartiality demanded of a judge." 189

Both the majority and the dissent recognize that Judge Wilkerson's comments cast doubt on his impartiality. The dissent seems clearly wrong in saying that the comments do not "relate ... to political and community social concerns." It is an open question whether homosexuality is normal or disordered, ${ }^{190}$ and this question is relevant to the legal treatment of homosexuality, just as questions about innate cognitive differences between the sexes are relevant to legal issues. It is hard to imagine a judge being punished for saying that those who oppose gay rights are homophobic, although that statement might cause such people to doubt whether they would be treated impartially by the judge. In that case, as in Judge Wilkerson's, the majority's approach seems wisest - to desist from punishment but to recognize that the judge may have to recuse himself when those he has disparaged so request. His comments did not allude to religion and do not seem to have been religiously inspired, but they addressed a matter of public concern on which a judge should be free to speak.

186 Id. at 1022.

187 Id. at 1023 .

188 Id. at 1025 .

189 Id.

190 "There are millions of citizens who believe Judge Wilkerson's religious views are exactly correct. There are still millions more who find his views insulting." Id. at 1014 (majority opinion) 
e. Vernon v. City of Los Angeles. ${ }^{191}$-Robert Vernon was the assistant chief of police in the Los Angeles Police Department ("LAPD"). A 1991 magazine article quoted from audiotapes of Vernon speaking as an elder of the Grace Community Church fifteen years earlier. The article said Vernon 'condemns homosexuality, depicts cops as 'ministers of God,' instructs churchgoers that 'the woman is to be submissive to the man' and adjures men to 'recognize the concept of disciplining followers, whether it be your son, employees or anyone under your control-your wife.", 192

The article triggered demands to investigate whether Vernon's views "interfere with [his] ability to perform official duties fairly and without bias," specifically with respect to the "treatment of gays and lesbians." The chief of police did investigate and found that the fears about Vernon were not substantiated. No action was taken against him.

Vernon then sued the city and those involved in the investigation for violations of the Free Exercise, Establishment, Due Process, and Equal Protection clauses of the Constitution. He alleged that the investigation and accompanying publicity caused him emotional distress, interfered with his personal and professional activities, and damaged his personal and professional reputation. The district court granted defendants' motion for summary judgment. The appellate court affirmed. ${ }^{195}$

The court applied the compelling interest test to Vernon's free exercise claim. ${ }^{196}$ The court found that Vernon "failed to demonstrate a substantial burden" on his religious exercise. ${ }^{197}$ To prevail, Vernon had to show government action; pressuring him or her to commit an act forbidden by the religion or preventing him or her from engaging in conduct or having a religious experience which the faith mandates. This interference must be more than an inconvenience; the burden must be substantial and an interference with a tenet or belief that is central to religious doctrine. "'It is thus inadequate for a plaintiff merely to allege that government action sub-

19I Vernon v. City of Los Angeles, 27 F.3d 1385 (9th Cir.), cert. denied, 513 U.S. 1000 (1994). at 28).

192 Id. at 1388 (quoting The Dan Quayle Principle Strikes Again, L.A. MAG., May 21, 1991,

$193 \mathrm{Id}$. at $\mathrm{I} 389$ (quoting a letter from Councilman Zev Yaroslavsky to the President of the Board of Police Commissioners ("BCP")). In response, the BCP asked the Chief of Police to investigate Vernon.

$194 I d$. at 1390 .

$195 \mathrm{Id}$. at 1402 .

$196 \mathrm{Id}$. at 1392 . The court did so in part because of the Religious Freedom Restoration Act of 1993,42 U.S.C. $\$ 2000 b b$ (2000), which was subsequently held unconstitutional by the Supreme Court. See City of Boerne v. Flores, 52 I U.S. 507 ( 1997 ).

197 Vernon, 27 F.3 d at 1393 .

198 Id. 
jectively "chills" his religious behavior, especially where the government action is neither regulatory, proscriptive, or compulsory in nature.", 199

Vernon failed to make an adequate showing: "There is simply no evidence that the City ever monitored Vernon's private religious activities .. .. [T] he investigation was restricted ... to consideration only of Vernon's on-duty activities and .... it resulted in no disciplinary action" against him. Thus he "failed to show any concrete and demonstrable injury."200 "[C]hilling effects are simply not objectively discernable and are therefore not constitutionally cognizable." ${ }^{201}$

The court also rejected the Establishment Clause claim under the three-prong test of Lemon v. Kurtzman. ${ }^{202}$ As to the second prong of the test-whether the government act has the primary effect of advancing or inhibiting religion-the court concluded that although one might "infer possible city disapproval of Vernon's religious beliefs from the direction of the investigation, this could not objectively be construed as the primary focus or effect of the investigation." ${ }^{203}$ If plaintiff has the burden of proving perceptions of the public and of Los Angeles municipal employees and failed to do so here, the court's determination may be correct. It would be interesting, though, to have a survey of those perceptions; perhaps the public did see the investigation as manifesting hostility to Vernon's faith.

Vernon seems to apply precedent accurately, ${ }^{204}$ but the decision is still troubling. Over six months elapsed between publication of the magazine article and completion of the investigation. The investigation concerned only statements outside of work that should probably be protected free speech; it is all the more disturbing that they were statements of religious beliefs made in church. These gave no indication that Vernon had or would mistreat homosexuals, and there were no allegations that he had done so. The LAPD did not ask him to explain his views or to confirm that he did not, and would not, mistreat gays or women.

Employees often hide attitudes, including religious views, that they fear their superiors dislike. It would create chaos if an employee could sue every time she felt pressure to disguise her religious beliefs from superiors. When an employee is subjected to a lengthy formal investigation solely

199 Id. at 1394 (quoting the district court opinion).

200 Id. at $\mathrm{I} 395$.

201 Id.

202 Lemon v. Kurtzman, 403 U.S. 602, 612-13 (1971).

203 Vernon, 27 F.3d at I398-99.

204 On the free exercise question, the court followed Laird v. Tatum, 408 U.S. I, I3-14 (1972) and Presbyterian Church (U.S.A.) v. United States, 870 F.2d 518, 522 (9th Cir. 1989). See Vernon, 27 F.3d at 1394 .

205 The article said Vernon "condemns homosexuality, depicts cops as 'ministers of God,' instructs churchgoers that 'the woman is to be submissive to the man' and adjures men 'to recognize the concept of disciplining followers, whether it be your son, employees or anyone under your control-your wife." Vernon, 27 F.3 at 1388. 
because of religious beliefs expressed in church, however, a due concern for religious freedom would offer relief.

f. Altman v. Minnesota Department of Corrections. ${ }^{206}$-Minnesota state employees were required to attend classes that some employees believed were "state-sponsored indoctrination designed to sanction, condone, promote, and otherwise approve behavior and a style of life that Appellants believe to be immoral, sinful, perverse, and contrary to the teachings of the Bible." ${ }^{207}$ They brought Bibles and read them silently during classes. They received reprimands that disqualified some for promotion. They sued. Applying Pickering, the Eighth Circuit held that plaintiffs had a valid complaint that the state had violated their freedoms of speech and religion. It therefore reversed the district court's grant of summary judgment for the defendant and remanded for further proceedings.

Although this decision is a welcome exception to the previous cases denying religious freedom to government employees, the ruling is limited; it seems to fault the state only for singling out plaintiffs' silent reading while other inattentive employees were not disciplined. Had the state insisted that all employees pay attention to indoctrination, evidently plaintiffs would have lost. That the state was teaching plaintiffs that their religion is wrong would not have violated their rights under Smith. The state may, of course, demand that its employees treat homosexuals equally, but to impose indoctrination about the propriety of homosexuality constitutes thought control incompatible with a free society.

g. Akridge v. Wilkinson. ${ }^{210}$-William Akridge, a full-time chaplain in the Ohio prison system, was fined and reassigned because he refused to let an active homosexual lead a band to play at religious services. Conceding that Akridge's act might constitute speech or expressive conduct concerning matters of public concern, the Court of Appeals applied the Pickering balancing test and upheld the state's action on the ground that it had an "interest in preventing discrimination."

206 Altman v. Minn. Dep't of Corr., 25 I F.3d I 199 (8th Cir. 200I).

207 Id. at 1201.

208 The state argued that the appellants were disciplined not for their nonverbal speech but for refusing to accept mandatory training. The court found this claim subject to dispute because "other employees have been similarly inattentive at . . training sessions, but none has ever been disciplined." Id. at 1203 . Thus the state's motive was a disputed issue of fact. Id.

209 However, the court affirmed dismissal of plaintiffs' free exercise claim on the ground that being denied the opportunity to read the Bible during this one session did not substantially burden the exercise of religion. Id. at $1203-04$.

2 Io Akridge v. Wilkinson, 178 F. App'x 474 (6th Cir. 2006).

21 I Id. at 480 . 
The decision is troubling because it lets the state overrule an ordained minister in the conduct of a religious service. Nonetheless, the result is defensible. Because prisoners are always in state custody, including during religious services, the state must be able to impose rules to maintain order and fair treatment of prisoners during such services. The state could decide that inclusion of homosexuals in religious services is preferable to excluding them. It could then hire a chaplain who would follow such a policy, and it did not have to allow a chaplain who favored a contrary policy to have his way. As Akridge argued, and the court apparently agreed, he was not required to implement a policy he considered sinful; he could have excluded the band from the services altogether. ${ }^{212}$ Further, it is not possible for the state to offer religious services reflecting the faith of every clergyman or inmate; choices must be made. One can question the wisdom of the choice made here, but the state had constitutional authority to make the choice.

h. Speech Codes.- In some government workplaces rules forbid negative comments by employees about homosexuality. ${ }^{213} \mathrm{It}$ is appropriate for government employers to forbid severe or persistent harassment, but some of these codes go much too far, especially given the public debate about the nature and propriety of homosexuality.

i. Religious Judges.-Some efforts have been made to disqualify judges because of their religious beliefs. ${ }^{214}$ So far these efforts have failed, but undoubtedly they will be made again, sometimes with claims that a judge with traditional religious beliefs about homosexuality should be barred from cases involving homosexuals. Of course, judges must always apply the law even when it clashes with their private beliefs. There is no reason to think judges cannot set aside their religious beliefs as much as any other.

2 I 2 Id.

213 See City of Los Angeles, Sexual. Orientation Discrimination Procedure, available at http://www.lacity.org/per/eeo/sexual\%20orientation\%2ocomplaint\% 2oprocedure.pdf (prohibiting "derogatory ... comments ... or jokes respecting sexual orientation"); State Univ. of N.Y. (Albany), Office of Diversity \& Affirmative Action, Sexual Orientation Discrimination and Harassment or Intolerance, http://www.albany.edu/affirmative_action/sexual_orientation. html (forbidding, e.g., “'jokes' that reinforce the false stereotypes related to lesbians, gays, transgendered persons, or bisexuals").

2 I 4 See Feminist Women's Health Ctr. v. Codispoti, 69 F.3d 399, 400 (9th Cir. I 995) (denying plaintiff's petition for removal of Catholic judges despite plaintiff's assertion that the judge's "fervently-held religious beliefs would compromise [his] ability to apply the law"); Idaho v. Freeman, 478 F. Supp. 33 (D. Idaho 1979) (seeking recusal of judge because he was a Mormon); see also Miss. Comm'n on Judicial Performance v. Wilkerson, 876 So.2d 1006 (Miss. 2004), discussed supra at notes I 73-90 and accompanying text. 
3. Governance of the Workplace--Boy Scouts $v$. Wyman. ${ }^{215}$ In 2000 the Connecticut Commission on Human Rights and Opportunities ("CHRO") removed the Boy Scouts of America ("BSA") from the state's workplace charitable campaign because the BSA discriminated against homosexuals in violation of the state's Gay Rights Law. The BSA challenged the removal under the First Amendment and state law. In Wyman, the Court of Appeals affirmed summary judgment for defendants. ${ }^{216}$ It found that the Gay Rights Law was "viewpoint neutral" because it governs conduct that is not "primarily expressive" and its differential impact on viewpoints was coincidental, not intentional. ${ }^{217}$ The law's purpose was to deter harmful conduct, so the exclusion did not violate the First Amendment.

Boy Scouts of America v. Dale ${ }^{218}$ confirms the Scouts' constitutional right as an expressive association to exclude gays from leadership positions. Wyman does not directly disturb the BSA's policy but does subject it to a heavy penalty. The Scouts rely on donations, and public employee charity campaigns are an important resource because they raise substantial funds at little cost to the recipients. As the court acknowledged, the state law "has a foreseeably adverse impact on the expressive abilities" and "will to some extent restrict the message" of the BSA. ${ }^{219}$ Moreover, despite the CHRO's claim that excluding the BSA from the campaign did not violate the state law's prohibition against "condon[ing] homosexuality," 220 the exclusion conveys endorsement of homosexuality and condemnation of disapproval of homosexuality. As the court concedes, the purpose of the law "is to discourage harmful conduct." ${ }^{221}$ In other words, the state has used the expressive function of the law to label the Boy Scouts' policy, based on traditional Judeo-Christian beliefs, as "harmful conduct."

The decision here is even more objectionable than that in Hicks. On one side, the harm to gays from the BSA's policy is minor. Few gays want to be scout leaders, and the position is voluntary, so the policy has almost no economic effect. Opponents of the Scouts' policy are free to set up their own children's organizations. On the other side, the BSA is an expressive organization, and scout leaders are the primary vehicles through which its beliefs are taught. By officially disdaining and imposing a financial penalty on the Boy Scouts' choice of its representatives, the state strikes at the heart of the BSA's ability to perform its mission.

215 Boy Scouts v. Wyman, 335 F.3d 80 (2d Cir. 2003), cert. denied, 541 U.S. 903 (2004).

216 See id.

217 Id. at $92-95$.

218 Boy Scouts of Am. v. Dale, 530 U.S. 640 (2000). For a discussion on Dale see supra notes $4 \mathrm{I}-50$ and accompanying text.

2 I 9 Dale, 335 F.3d at 93.

$220 \mathrm{Id}$. at 98.

$22 \mathrm{I} I d$. at 95 . 


\section{Government Contractors}

Government has broad discretion to impose conditions on the grant of government contracts, but this discretion is not unlimited, especially when it affects basic constitutional freedom. Government need not forbid acts by its contractors that would violate the Equal Protection Clause if done by the government itself. ${ }^{222}$ In Board of County Commissioners, Waubansee County ข. Umbehr ${ }^{223}$ the Supreme Court held that government contractors have some free speech protections and that the Pickering balancing test ${ }^{224}$ determines whether government rules are constitutionally permissible. In general, conditions attached to federal spending must be related to the enactment's purpose.

Applying this balancing test can be difficult. The Supreme Court has upheld laws forbidding discrimination by recipients of public funds, ${ }^{226}$ but a balancing test requires consideration of the unique facts of each case. In some cases the Supreme Court has found that the intrusion of the law in question on the recipient's constitutional rights was slight. ${ }^{227}$

Gauging the severity of the intrusion on a government contractor's constitutional freedoms should entail an inquiry like those in Dale and Hurley. That is, the court should ask whether the restriction seriously interferes with constitutional freedom and, if the contractor is an expressive association, with its ability to convey its message. Employment rules, for example, might be valid for a contractor's lower-level employees but not for policymaking or leadership positions. Of course, the balancing will differ from that in Hurley and Dale because those cases did not involve receipt of government money, which makes it harder to sustain the constitutional claim. However, as Umbehr holds, a recipient of government funds does not forfeit all constitutional rights; a balancing is still necessary. Moreover, it is arguable that the balancing formula should be more generous to the private party when it asserts religious freedom rather than free speech alone.

222 See Blum v. Yaretsky, 457 U.S. 99I, 1002 (1982). In any case, homosexuality is not a suspect class for purposes of the equal protection clause. See infra note 432.

223 Bd. of County Comm'rs v. Umbehr, 518 U.S. 668 (1996).

224 See supra notes $15 I$ and accompanying text.

225 South Dakota v. Dole, 483 U.S. 203, 207-08 (1987); see also New York v. United States, 505 U.S. 144, 167 (1992) (requiring that conditions "bear some relationship to the purpose of the federal spending").

226 See Univ. of Penn. v. EEOC, 493 U.S. 182 ( 1990 ) (upholding application of Title VII of the Civil Rights Act of 1964 to faculty hiring against claim that this violated the faculty's freedom of speech); Grove City Coll. v. Bell, 465 U.S. 555 (1984) (upholding application of Title IX of the Civil Rights Act of 1964 to college whose students received federal aid); Regents of Univ. of Cal. v. Bakke, 438 U.S. 265, 329-3I (1978).

227 See, e.g., Univ. of Penn. v. EEOC, 493 U.S. I 82, 200 ( 1990 ) (finding that any restriction on faculty's First Amendment rights was "remote and attenuated").

228 See infra notes $579-81$ and accompanying text. 
1. Okwedy v. Molinari. ${ }^{229}$ - In February 2000, plaintiffs Keyword Ministries, a Christian church, and its pastor Kristopher Okwedy contracted with PNE Media to display on a Staten Island, New York, billboard the Bible verse, "Thou shalt not lie with mankind as with womankind: it is abomination," ${ }^{230}$ and three other translations of the same passage. Soon after the billboards went up, PNE got a letter from Staten Island Borough President Guy Molinari stating that:

[T]his message conveys an atmosphere of intolerance which is not welcome in our borough.

P.N.E. Media owns a number of billboards on Staten Island and derives substantial economic benefits from them. I call on you as a responsible member of the business community to please contact Daniel L. Master, my legal counsel and Chair of my Anti-Bias Task Force ... to discuss further the issues I have raised in this letter.

The same day PNE removed the signs. Plaintiffs then sued Molinari and PNE for violations of the First Amendment and other laws. The district court dismissed the First Amendment claims on the grounds that Molinari did not have regulatory or decision-making authority over PNE and that his letter was "not reasonably susceptible to interpretation as threatening economic harm;" the letter merely "called for a dialogue" and could not "reasonably be viewed as designed to intimidate." 232

The court of appeals reversed. It said a First Amendment violation could be shown not only by "threatened use of official power by defendants ... but also the threatened use of other coercive means" such as urging a boycott. ${ }^{233}$ In finding that Molinari's letter could not "reasonably be viewed as designed to intimidate," the lower court failed to view the evidence in the light most favorable to the plaintiff, as it must do on a motion to dismiss; "a jury could find that Molinari's letter contained an implicit threat of retaliation if PNE failed to accede to Molinari's requests."

This conclusion is clearly correct. Molinari's letrer, sent by him "As Borough President of Staten Island," said the billboard "conveys an atmosphere of intolerance that is not welcome in our borough," referred to PNE's substantial business on Staten Island, and urged PNE to call Molinari's legal counsel and chair of his Anti-Bias Task Force. Molinari was also clearly able, in his official position, to injure PNE by a legal investigation that would be expensive to defend, by withholding government business

229 Okwedy v. Molinari, 333 F.3d 339 (2d Cir. 2003).

230 Leviticus 18:22 (King James).

231 Okwedy, 333 F.3d at 342.

232 Okwedy v. Molinari, 150 F. Supp. 2d 508, 518 (E.D.N.Y. 2001).

233 Okroedy, 333 F.3d at 343.

234 Id. at 344. 
from PNE, and by exhorting private entities to do likewise. PNE would be foolish to ignore this danger.

2. Catholic Charities of Maine, Inc. v. City of Portland. ${ }^{235}$ - The City of Portland has a law requiring any entity taking Housing and Community Development ("HCD") funds from the city to give the same health and fringe benefits to employees with domestic partners as to employees with spouses. The city withheld HCD funds slated for Catholic Charities of Maine ("CCM"), an organization with close ties to the Catholic Church, because CCM refused to obey that law. ${ }^{236}$ CCM sued the city, claiming violations, inter alia, of the Employee Retirement Income Security Act of 1974 ("ERISA") 237 and the United States Constitution.

The court first held that application of the law to CCM was preempted by ERISA after CCM elected to be covered by ERISA in $2003 .{ }^{239}$ It then rejected CCM's free exercise claim under $S$ mith on the ground that the law was generally applicable and neutral. ${ }^{240}$ The court also questioned whether the law "substantially burdened" CCM since it had actually provided the intended service programs without HCD funds.

CCM also argued that the ordinance violated its free speech because "by not providing domestic partner benefits, [CCM] sends a message about Roman Catholic teaching on non-family relationships." The court said that "[c]onduct constitutes protected expression if 'it evinces an intent to convey a particularized message ... and the likelihood is great that the message would be understood by those [to whom it is addressed]." ${ }^{242}$ Here, "[r]here simply is no 'particularized message' in the provision of employee benefits, let alone a message that would be understood by the public." ${ }^{243}$ The court then denied CCM's claim that the ordinance imposed an unconstitutional condition because the condition "must implicate a constitutional right"

235 Catholic Charities of Me., Inc. v. City of Portland, 304 F. Supp. $2 d 77$ (D. Me. 2004).

236 Id. at 83 .

23729 U.S.C. § 1001 (2000).

238 Similar issues arise in Titus Construction $v$. City of Minneapolis, a challenge to a Minneapolis law requiring city contractors to give unmarried employees and their partners the same benefits as married couples. See Alliance Defense Fund, Will Minneapolis Require Companies to Subsidize Unmarried Partners?, http://www.alliancedefensefund.org/story/ ?id $=393$.

239 City of Portland, 304 F. Supp. $2 \mathrm{~d}$ at $84-93$.

240 Id. at $94-95$.

24 I Id. at 94 .

242 Id. at 95 (quoting Gun Owners' Action League v. Swift, 284 F.3d 210,21 I (Ist Cir. 2002) (quoting Texas v. Johnson, 491 U.S. 397,404 (i 989 ))).

243 Id. For the same reason, the court said that compelling CCM to provide domestic partner benefits did not "compel" it "to endorse any particular message." Id. 
and CCM "does not have a constitutional right to administer its employee benefit plans in the manner it chooses."

The decision is troubling on several grounds. Its conclusion that denial of HCD funds did not "substantially burden" CCM because it "was able to provide the service programs without the benefit of HCD funds" is ridiculous. The court said CCM carried out the programs "at least in part ....",245 There was no finding that CCM completed the programs. More important, a charitable organization like CCM does all the good it can; it can never meet all needs. If CCM carried out HCD programs with its own funds, it would have lost the ability to pursue its mission elsewhere.

Second, the court failed to consider whether Smith applies not only to individuals but to organizations, for which the constitutional analysis is arguably different. ${ }^{246}$ If Smith does not apply, the court would have to ask whether the law imposed an unconstitutional condition. As the court said, "[w]hen the benefit is discretionary, the condition attached to receipt of the benefit must bear some connection to the rationale the government would employ in denying the benefit outright." ${ }^{247}$ It is hard to see any connection between the law's requirement of domestic partner benefits and the provision of aid to the needy for which HCD funds are intended.

3. Catholic Adoption Agencies in Massachusetts.-Massachusetts decided not to fund adoption agencies that discriminate against homosexual couples seeking to adopt. For many years Catholic Charities of Massachusetts (another "CCM") received state funds to arrange adoptions, but it could not comply with the new policy and ceased operations. ${ }^{48}$ Since the policy concerns the very activity for which state funds are given, it is hard to argue that the state is constitutionally required to grant the exemption. As a policy matter, however, CCM should have been granted an exemption. There are many adoption agencies in Massachusetts; an exemption for CCM still leaves many agencies that will serve gay couples. Gay couples are a very

244 Id. at $95-96$.

$245 \mathrm{Id}$. at 84.

246 See supra notes $24-26$ and accompanying text. The decision is arguably supported by recent cases holding that a state may require employers to include contraception in any employee health coverage. See Catholic Charities of Sacramento v. Superior Court, 85 P.3d 67 (Cal.), cert. denied, 543 U.S. 816 (2004); Catholic Charities of the Diocese of Albany v. Serio, 808 N.Y.S. 2d 447 (2006). Apart from the possibility that these cases are wrong, there are two possible differences between them and Catholic Charities of Maine. The government's need to require contraceptive care coverage may be greater than its need to mandate benefits for homosexual domestic partners. Second, in Catholic Charities of Maine, the claim for such a need is undermined by the application of the law only to government contractors.

247 City of Portland, 304 F. Supp. 2d at 95.

248 See Patricia Wen, They Cared for the Children: Amid Shifting Social Winds, Catholic Charities Prepares to End Its 103 Years of Finding Homes for Foster Children and Evolving Families, Boston Globe, June 25, 2006, at AI. 
small percentage of those seeking to adopt. Moreover, CCM has concentrated on the most difficult adoptive children, such as those with physical or behavioral problems. Denying funding to CCM will seriously harm these children without creating any substantial benefit for gays.

4. The Salvation Army in San Francisco.-In 1996, the San Francisco Board of Supervisors froze federal grants slated for a local emergency shelter run by the Salvation Army because a letter from an Army officer published in a local newspaper said that homosexuality "is contrary to the teachings of the Bible and presents a serious threat to the integrity, quality and solidarity of society as a whole." agreed to give homosexual sensitivity training to its officers and to add two homosexuals to its advisory council.

This case is particularly disturbing because there were no allegations that the Salvation Army discriminated against homosexuals; ${ }^{251}$ it was punished merely because of its declared principles. The Salvation Army is an expressive association so it might have won had it fought the Board in court, but that would at least have entailed expensive litigation and probably suspension of care for the homeless. Political power can infringe religious freedom even when its use may be illegal.

\section{Use of Public Facilities}

Since 1957 the City of San Diego leased certain park lands to the Boy Scouts of America ("BSA"). Because of the Scouts' exclusion of open homosexuals, agnostics, and atheists from leadership positions, some citizens of San Diego sued the city and the BSA alleging several constitutional violations. In Barnes-Wallace v. Boy Scouts of America, the court held that the leases violated the Establishment Clause because the BSA is a religious organization and the city did not use a religion-neutral process in deciding to lease the land to the BSA.

Although the city leases public land to other non-profit entities, the leases here resulted from exclusive negotiations with the BSA; other organizations were not allowed to compete for them. ${ }^{253}$ No other organization ever showed interest in replacing the BSA in these leases, but the court

249 Letter from Capt. Samuel Southard (date omitted) (quoted in Catherine Bowman, S.F. Freezes Funds for Salvation Army, S.F. ChroN., Jan. 3, 1996, at AI3).

250 See Steven A. Chin, Shelter OK'd After No-Gay Bias Pledge, S.F. Examiner, Jan. I 7, 1996, at A3; Editorial, Fund The Salvation Army, S.F. Chron., Jan. 5, 1996, at A22.

251 See Editorial, Fund the Salvation Army, S.F. Chron., Jan. 5, 1996, at A22.

252 Barnes-Wallace v. Boy Scouts of Am., 275 F. Supp. 2d 1 259, $1266-76$ (S.D. Cal. 2003). The court found no violation of the equal protection clause or of state common law. $I d$. at I $280-87$.

$253 \mathrm{Id}$. at 1274 . 
found that fact insufficient to make the leasing process religion-neutral because "[t]he burden ... was on the City to take affirmative steps to avoid an Establishment Clause violation by making the lease available to the religious, areligious and irreligious on a neutral basis." ${ }^{254}$ The court concluded that "[a] reasonable observer would most naturally view" these actions "as the City's endorsement of the [BSA] because of its inherently religious program and practices." 255

This conclusion is astonishing. Although religion is part of the Scouts' program, it is better known, and rightly so, for promoting outdoor activities, practical skills, personal responsibility, and teamwork. The city never refused similar treatment to an organization that supported these activities but eschewed the Scouts' religious attitudes. Rather, the city leased other tracts to a variety of organizations. The city also required the BSA to admit others to the leased land, except when the BSA was using it, without discrimination based on, among other things, religion and sexual orientation. ${ }^{256}$ For all these reasons, no one could reasonably construe the city's leases as endorsing the Scouts' religious beliefs.

The court in Barnes-Wallace also rejected the BSA's claim that cancellation of its leases would constitute viewpoint discrimination forbidden by the Supreme Court in Rosenberger $v$. Rector and Visitors of the University of Virginia. ${ }^{257}$ The court said Rosenberger requires viewpoint neutrality only for a general program supporting expressive activity, which San Diego did not have. ${ }^{258}$ The court added in dictum:

Defendants' argument would fail even if the City decided not to lease the parkland to the [BSA] because of its discriminatory membership policy. The government's decision to exclude organizations with discriminatory membership policies is viewpoint neutral when the purpose for the decision is to protect persons from the effects of discrimination and not to exact a price for the organization's protected expression.

This position is so extreme that one wonders whether the judges gave any thought to what they said. Almost all religions have moral standards that members are exhorted to follow. If Barnes-Wallace means what it says, all these religions are guilty of heinous discrimination. Must the city then bar all from its facilities if it bars any, or can it indulge in its own discrimination, deciding which faiths are good and which are evil? Can (or must) it,

254 Id. at 1275 .

255 Id. at 1276.

256 Id. at 1264.

257 Rosenberger v. Rector and Visitors of the Univ. of Va., 515 U.S. 819 (1995).

258 Bames-Wallace, 275 F. Supp. $2 \mathrm{~d}$ at $1287-88$.

259 Id. at 1288 . On this point the court relied on Boy Scouts of America $v$. Wyman, discussed supra at notes $215^{-17}$ and accompanying text. 
for example, bar Jews because they believe they are God's chosen people and others are not?

The question whether Scouts' have a constitutional right to access to government facilities was directly presented in Evans v. City of Berkeley, ${ }^{260}$ in which the Sea Scouts challenged the city's termination of their use of a city marina because the Scouts' discriminate against homosexuals and atheists. The California Supreme Court affirmed the trial court's dismissal of the suit. It held that Berkeley's requirement that a group receiving free marina berths agree "to administer its program without invidious discrimination did not infringe on plaintiffs' speech or associational rights." ${ }^{261}$ The court noted that the city had not forbidden the Scouts to discriminate but had merely denied a subsidy, and that the Supreme Court "has generally approved against First Amendment challenges programs of governmental financial assistance that limit the expressive activities for which the funds may be used." 262

This decision may correctly interpret Supreme Court rulings, but it is still disturbing. Although the city's policy technically applies to conduct, not speech, it clearly puts the city on record as materially assisting one side in a major cultural dispute-a dispute involving religion. By the court's reasoning, the city could presumably deny benefits to religious organizations that admit only men into the priesthood. In effect, the city officially denounced traditional Judaism and Christianity.

The court also rejected the Scouts' claim that they met the city's rule because in fact they did not discriminate against gays and promised to obey all applicable laws; they resisted only the city's demand that they explcitly "state a policy that the group would not, in the future, discriminate." ${ }^{263}$ Again, the decision may properly apply Supreme Court precedent. Although the state cannot compel speech by criminal sanctions, under $E v-$ ans it can condition a benefit on an oath to ignore the tenets of one's religion. $^{264}$

This case involves no monopoly or unique resource; the Scouts and groups with different principles could all use the city's marina. By virtue of Dale, the city could not fine the Scouts' $\$ 100$ for their practices, but the city could lavish subsidies worth thousands of dollars on competing groups while denying that benefit to the Scouts. This allows government to wound or destroy viewpoints it dislikes. Accordingly, these cases differ from those in which the state deploys its own speech to favor one side of a debate.

260 Evans v. City of Berkeley, 129 P.3d 394 (Cal. 2006).

26I Id. at 400 . The Scouts were free to use the marina if they paid the fee charged to other users who did not qualify for the subsidy. Id.

262 Id.

263 Id. at 398.

264 For this principle the court cited Grove City College v. Bell, 465 U.S. 555 (1984). 
Even if the Constitution permits such material discrimination, it is unfortunate that governments engage in it.

A more reasonable decision is Boy Scouts of America v. Till. ${ }^{265}$ The Broward (Florida) County School Board denied the Scouts after-hours use of public school facilities that are routinely granted to non-profit groups under a rule barring discrimination based on, inter alia, sexual orientation. In granting the Scouts a preliminary injunction the court noted that the school board "concedes that ... it has created a limited public forum" 266 in which the Board could not "discriminate against speech on the basis of its viewpoint." "267 The court denied the Board's claim that this was not a "limited public forum" because the Scouts draw their members partly from the school's student body and its leaders partly from the school's teachers.

The Scouts are now assured equal access to public schools by the Boy Scouts of America Equal Access Act. ${ }^{269}$ Congress and state legislatures should enact more such laws to protect expressive associations from discrimination by local governments.

\section{E. Students in Public Educational Institutions}

No terrain is more eagerly sought by gay activists than public schools and universities. $^{270}$ In many cases they have instituted programs to condone homosexuality even for the youngest students. ${ }^{271}$ In some cases these programs expressly disapprove traditional religious attitudes toward homosexuality. One university department issued a policy statement that "[i]t

265 Boy Scouts of America v. Till, 136 F. Supp. 2d 1295 (S.D. Fla. 2001).

266 Id. at 1308.

267 Id. (citing Lamb's Chapel v. Ctr. Moriches Union Free Sch. Dist., 508 U.S. 384, 39293 (1993)).

268 Id. at 13 10. In Focus on the Family v. Pinellas Suncoast Transit Authority ("PSTA"), 344 F.3d 1263 (1 1 th Cir. 2003), the PSTA refused to sell advertising space to Focus on the Family, an evangelical organization, to announce its forthcoming convention with the words "Love Won Out: Addressing, Understanding and Preventing Homosexuality in Youth." The trial court dismissed on standing grounds; the court of appeals reversed. The parties then settled, with PSTA agreeing to post an amended ad. See Press Release, Liberty Counsel, Focus on the Family Settles Lawsuit Allowing it to Advertise Pro-Family Conference on Bus Shelters (Oct. I3, 2004), http://www.lc.org/pressrelease/2004/nr 101304.htm. This case should be governed by the principle that government cannot discriminate based on viewpoint when it creates a limited open forum. See infra note 282 and accompanying text.

269 See 20 U.S.C.A. $\$ 7905$ (West 2006).

270 See Stephen Bates, Battleground: One Mother's Crusade, the Religious Right, and the Struggle for Control of Our Classrooms (I 993); Midge Decter, Homosexuality and the Schools, Comment., Mar. I993, at 19.

271 A New York City Board of Education manual instructs first grade teachers to give children "actual experiences via creative play, books, visitors, etc." so that they will "appreciate" gays. Bd. of Educ. of the City of N.Y., Children of the Rainbow: First Grade 372 (I991) (quoted in Duncan, supra note 7, at 414 n.78). 
is simply not acceptable for social workers to view homosexual people as perverse or as sinners .... It is not $\mathrm{OK}$ in this case to "love the sinner and hate the $\sin . "{ }^{272}$ Some policies virtually promote homosexuality to teenagers, who are often baffled about their own sexuality. ${ }^{273}$ Some religious rights groups are appealing to allow the voicing of traditional views of homosexuality. ${ }^{274}$ The following discusses some specific issues that have arisen in public schools and colleges.

1. Student Organizations.-Courts have divided on whether faith-based student organizations may exclude from leadership positions, or from membership altogether, students who reject the organization's religion. In Alpha Iota Omega Christian Fraternity v. Moeser ${ }^{275}$ and in Christian Legal Society v. Walker, ${ }^{276}$ courts preliminarily enjoined universities from enforcing similar rules against Christian fraternities. A suit by the Christian Legal Society challenging a similar rule was rendered moot when the school agreed to change its rule and recognize the CLS chapter. ${ }^{277}$ In Christian Legal Society Chapter of the University of California $v$. Kane, ${ }^{278}$ the court rejected the Society's Establishment Clause, due process, and equal protection claims against a similar rule. However, the court did not address the Society's charge that the rule violated its freedoms of speech and expressive association.

Under Dale these should be easy cases. ${ }^{279}$ The student groups are clearly expressive associations. Admitting people who reject the faith that is the organization's raison d'etre would distort its message at least as much as

272 Maura Lerner, St. Cloud State's Department Statement on Gays Causes Backlash, Minneapolis STaR Trib., June I, I993, at 9A. Criticism of this statement resulted in only a minor change. Id.

273 In a "role reversal" exercise, tenth graders at Framingham (Ma.) High School were asked: "Is it possible you are heterosexual because you fear the same sex? If you have never slept with someone of the same sex, how do you know you wouldn't prefer that? Is it possible you merely need a good gay experience?" Richard F. Duncan, Homosexual Marriage and the Myth of Tolerance: Is Cardinal O'Connor a "Homophobe"?, io Notre Dame J.L. Ethics \& Pub. PoL'y 587, 600 n. 68 (1996) (citation omitted).

274 Liberty Counsel is one of these groups. Its activities are described at its web site, http://www.lc.org.

275 Alpha Iota Omega Christian Fraternity v. Moeser, No. Civ. 1:04CVo0765, 2005 WL I 720903 (M.D.N.C. Mar. 2, 2005).

276 Christian Legal Soc'y v. Walker, 453 F.3d 853 (7th Cir. 2006).

277 See Foundation for Individual Rights in Education, Victory for Religious Freedom at Ohio State, Oct. 4, 2004, available at http://www.thefire.org/index.php/article/4895.html.

278 Christian Legal Soc'y Chapter of the Univ. of Cal. v. Kane, No. C 04-4484 JSW, 2005 WL 850864 (N.D. Cal. Apr. 12, 2005).

279 See supra note 4 I and accompanying text. See also Healy v. James, 408 U.S. I69 (1972), in which the Supreme Court held that a public university's refusal to grant student organization status to Students for a Democratic Society violated the members' First Amendment right of association. 
would the appointment of a gay assistant scoutmaster in Dale. These are not mass organizations like AARP or AAA with thousands of uninvolved members whose identities and beliefs are largely irrelevant. Frequent fellowship in a small group based on shared faith is a central purpose of most of these societies. Admitting members who deny their creed would largely destroy this activity.

Rules forbidding discrimination based on religion or sexual orientation may be proper for most nonreligious school groups since these characteristics are irrelevant to the purposes of these groups. ${ }^{280}$ To apply such rules to religious groups, though, imposes an orthodoxy of thought; the school declares that forming a group based on religious belief is wrong. This is unconstitutional viewpoint discrimination by university officials, who should celebrate diversity of thought. ${ }^{281}$ Other student organizations may exclude those who reject their beliefs; a vegetarian society may exclude carnivores. Only religious groups are forbidden to limit their membership. Public universities may not so discriminate. ${ }^{282}$ Although unnecessary to the constitutional analysis, note that rules against religious discrimination are especially threatening to minority beliefs. If compelled to admit those who reject their faith, societies of religious minorities could be disrupted or overwhelmed by outsiders.

Rules barring discrimination based on sexual conduct generate the same problems since sexual morality is integral to most religious faiths. Again, if the vegetarian society may exclude carnivores, a faith-based group committed to marital fidelity should be able to exclude adulterers and those who condone adultery.

280 An exception would be a society with a secular purpose that is incompatible with certain religious beliefs. A temperance group, for example, might legitimately exclude members of faiths that make ceremonial use of alcohol.

28I See Hurley v. Irish-American Gay, Lesbian \& Bisexual Group of Boston, Inc., 515 U.S. 557,578 (1995) (forbidding imposition of antidiscrimination law where "the ultimate point of forbidding acts of discrimination toward certain classes is to produce a society free of the corresponding biases."); Note, Leaving Religious Students Speechless: Public University Antidiscrimination Policies and Religious Student Organizations, I 8 HaRv. L. Rev. 2882, 2892 (2005) (hereinafter "Leaving Religious Students Speechless").

282 See Rosenberger v. Rector \& Visitors of Univ. of Va., 5 I 5 U.S. 8 I 9 (1995) (holding that university could not exclude journals discussing issues from a religious perspective from a system of subsidies for student journals to discuss public issues).

283 Although I am not aware of any case where this has happened to a religious group, republicans once seized control of the Young Democrats at the University of Nebraska. See Leaving Religious Students Speechless, supra note 28I, at 2885 n.20 (citing Wendy Mott, College Republicans Elected to Young Democrats' Offices, Daily Nebraskan, Apr. I6, 1993, at 1).

284 Rules against discrimination based on sexual orientation but not on sexual conduct are acceptable to the many denominations that distinguish between the two. See infra notes $527-29$. 


\section{Individual Students.-In Tinker ข. Des Moines Independent Community} School District, the Supreme Court decreed that public school students do not "shed their constitutional rights to freedom of speech or expression at the schoolhouse gate." ${ }^{285}$ However, in Bethel School District No. 403 v. Fraser, the Court said "the constitutional rights of students in public schools are not automatically coextensive with the rights of adults in other settings." 286 In Hazelwood v. Kuhlmeier, the Court said students "cannot be punished merely for expressing their personal views on the school premises ... unless school authorities have reason to believe that such expression will 'substantially interfere with the work of the school or impinge upon the rights of other students." "287 "The determination of what manner of speech in the classroom or in school assembly is inappropriate properly rests with the school board." "288 The Ninth Circuit has construed Hazelwood to allow school officials to "suppress speech that is vulgar, lewd, obscene, or plainly offensive without a showing that such speech occurred during a schoolsponsored event or threatened to 'substantially interfere with the school's work." "289 Other courts of appeals have limited suppression to speech that is indecent.

K-12 public schools have more leeway to restrict speech than do public universities. $^{291}$ This makes sense; school attendance is mandatory at the $\mathrm{K}-12$ level, and $\mathrm{K}-12$ students are less mature and less able to avoid or to cope with unwanted or offensive speech than are university students. The precise boundaries of the schools' authority and, correspondingly, of the rights of students and teachers, is worked out in individual cases.

Poway (California) School District decreed a Day of Silence, which student Tyler Harper believed "endorsed, encouraged, subsidized and promoted" homosexual activity. ${ }^{292}$ The court did not find that belief unreasonable.

285 Tinker v. Des Moines Indep. Cmty. Sch. Dist., 393 U.S. 503, 506 ( I 969 ).

286 Bethel Sch. Dist. No. 403 v. Fraser, 478 U.S. 675, 682 (1986).

287 Hazelwood v. Kuhlmeier, 484 U.S. 260, 266 (1988) (quoting Tinker, 393 U.S. at 509).

288 Fraser, 478 U.S. at 683.

289 Chandler v. McMinnville Sch. Dist., 978 F.2d 524, 529 (9th Cir. 1992).

290 See Sypniewski v. Warren Hills Reg'l Bd., 307 F.3d 243, 254 (3d Cir. 2002); Saxe v. State Coll. Area Sch. Dist., 240 F.3d 200, 216 (3d Cir. 200I).

291 In Fraser, the Court said that public schools may bar "lewd, indecent, or offensive speech and conduct ...." Fraser, 478 U.S. at 683 . The Court upheld the suspension of a student who used "an elaborate, graphic, and explicit sexual metaphor" in a student assembly. Id. at 678 . In Kuhlmeier the Court upheld suppression from a student newspaper of stories in a journalism class about a student's pregnancy and divorce of a student's parents. The Court said these were "school-sponsored expressive activities" and the actions were "reasonably related to legitimate pedagogical concerns." Kuhlmeier, 484 U.S. at 273. See generally HarveY A. Silverglate et al., Guide to Free Speech on Campus 44-49 (2005).

292 Harper v. Poway Unified Sch. Dist., 345 F. Supp.2d 1096, I 100 (S.D. Cal. 2004) (Hanper $I$ ) (quoting plaintiff's complaint), aff'd, 445 F. 3 d I 66 (gth Cir. 2006) (Harper II). A school official said the purpose of the Day of Silence is to "'teach tolerance of others, particularly those of a different sexual orientation." Harper $I I, 445$ F.3d at 1 I 71 . 
Wishing to express his religious belief about "the Biblical condemnation of homosexual behavior to others in his school and his community" on that day, Harper wore a T-shirt with the words "I WILL NOT ACCEPT WHAT GOD HAS CONDEMNED" on the front and "HOMOSEXUALITY IS SHAMEFUL 'Romans 1:27'" on the back. ${ }^{293}$ The next day he wore a T-shirt that read "BE ASHAMED" and "OUR SCHOOL EMBRACED WHAT GOD HAS CONDEMNED" on the front and the same quote from Romans on the back. Harper was sent to several school officials and, finally, to the school's principal, who told him the T-shirt was "inflammatory" and "too 'aggressive' and that wearing it would not be tolerated" at the school. ${ }^{294}$ Harper refused to remove the shirt, so he was confined to the principal's office for the rest of the school day.

Several school and government officials later spoke to Harper. A deputy sheriff sporting a gun went "to determine if [plaintiff] was a dangerous student." He "suggested plaintiff should 'not be offensive to others' because the Christian faith is not based on hate and ... that the T-shirt was 'inflammatory' and 'could encourage uprising and violence against homosexuals." ${ }^{295}$ A school vice principal told Harper that when he came to school he must "leave his faith in the car." leave the school.

The trial court denied plaintiff's motion for summary judgment. ${ }^{297}$ On Harper's appeal, the Court of Appeals affirmed, 2-1, on different grounds. It held that the school could bar Harper's $t$-shirt because it would "impinge upon the rights of other students" ${ }^{298}$ and was "[s]peech that attacks high school students who are members of minority groups that have historically been oppressed." ${ }^{299}$ The majority denied that the school could ban all "derogatory" speech; it could not, for example, forbid the statement "Young Republicans Suck ...." ${ }^{300}$ But it could bar statements critical of homosexuality, which it characterized as "a core characteristic of particularly vulnerable students ....,"301

293 Harper I, 345 F. Supp. 2d at 1100.

294 Id.

295 Id. at n 10 I (quoting plaintiff's complaint).

296 Id.

297 Id. at 1099.

298 Harper $I I, 445$ F.3d at 11 77-78 (quoting Chandler v. McMinnville Sch. Dist., 978 F.2d 524, 529 (9th Cir. 1992) (quoting Tinker v. Des Moines Indep. Cmty. Sch. Dist., 393 U.S. 503, $509(1969)))$.

$299 \mathrm{ld}$. at I 78 . The trial court had denied Harper's motion because it could not decide without extrinsic evidence whether his T-shirts were "plainly offensive" or disruptive. Harper $I, 345$ F. Supp. 2d at $1105-06$.

300 Id. at 1182 .

301 Id. 
The majority conceded that the school's action was viewpoint discrimination but said it was not unconstitutional because schools may "inculcat[e] fundamental values necessary to the maintenance of a democratic political system," ${ }^{302}$ including tolerance, ${ }^{303}$ "even if the message conflicts with the views of a particular religion." ${ }^{304}$ The majority maintained that schools may not "restrict the non-invasive, non-disruptive expression of political viewpoints . .." but, as Judge Kozinski noted in dissent, it is unclear how Harper could have expressed his view while satisfying the court in that regard. ${ }^{306}$ Harper believes homosexuality is immoral and sinful. The offending T-shirts said "Homosexuality is shameful." It does not seem that any different phrase could have communicated his message and still meet the majority's approval.

As Judge Kozinski noted further, the decision is more disturbing because Harper's action was not taken sua sponte but in response to the school's sponsoring of the Day of Silence, a national effort to promote acceptance of homosexuality. ${ }^{307}$ Thus the school did not simply forbid all expressionpositive or negative-regarding homosexuality, nor did it simply suppress one side of the debate. Rather it gagged one side while actively supporting the other. Judge Kozinski noted the hypocrisy of taking such action in the name of promoting tolerance. ${ }^{308}$ Presumably, then, the school could also actively condemn Christianity, Judaism, and Islam because of their stands on homosexuality.

Other cases have barred school officials from banning student apparel just because it bears a provocative message. In Tinker itself, the Supreme Court upheld the right of a student to wear a black armband to protest the war in Vietnam. ${ }^{309}$ Castorina v. Madison County School Board upheld the right of a student to wear a T-shirt displaying Confederate flags and reading "Southern Thunder." And Barber v. Dearborn Public Schools upheld a student's right to wear a T-shirt with a photograph of President George W. Bush and the caption "International Terrorist." ${ }^{311}$ Again, Harper only denied summary judgment because the threat of disruption depended on specific facts. However, Harper's case is so strong on its face as to suggest that the court denied relief simply because it disapproved of Harper's message.

302 Id. at I 190, (quoting Bethel Sch. Dist. No. 403 v. Fraser, 478 U.S. 675, 683 (1986)).

303 Harper II, 445 F.3d at 1185 .

304 Id. at I 190.

305 Id. at 1185 .

$306 \mathrm{Id}$. at 1206 .

307 Id. at 1196.

308 Id. at I I 97 .

309 Tinker v. Des Moines Indep. Cmty. Sch. Dist., 393 U.S. 503 (1969).

3 Io Castorina v. Madison County Sch. Bd., 246 F.3d 536, 539 (6th Cir. 2001).

31 I Barber v. Dearborn Pub. Sch., 286 F. Supp.2d 847, 849 (E.D. Mich. 2003). 
A more sympathetic view of First Amendment rights prevailed in Hansen v. Ann Arbor Public Schools. ${ }^{312}$ In 2002 Pioneer (Michigan) High School held a Diversity Week, as it had for at least ten years. The event included several assemblies with panel discussions. The school's Gay/Straight Alliance ("GSA") was authorized to present a panel on Religion and Homosexuality. The GSA, wanting a panel that was "gay friendly,", chose "six pro-homosexual adult clergy and religious leaders" plaintiff Betsy Hansen and several other students to include at least one speaker to present an opposing view.

Instead Hansen was invited to give a two-minute speech at an assembly beginning Diversity Week. However, she had to submit her speech in advance for review by school officials who disapproved a statement that "[s] exuality implies an action, and there are people who have been straight, then gay, then straight again. I completely and whole-heartedly support racial diversity, but I can't accept religious and sexual ideas or actions that are wrong." ${ }^{315}$ School officials found this speech "objectionable because it targeted an individual and groups, specifically homosexuals."

The court said that because the context was a school assembly, this was not a case of individual freedom of speech controlled by Tinker. However, since students were presented as stating their own opinions, neither was it a case of "government speech" in which "it may make viewpoint-based choices and choose what to say and what not to say." sponsored speech, i.e., "[e]xpressive activities that students, parents, and members of the public might reasonably perceive to bear the imprimatur of the school." ${ }^{318}$ Therefore, the case was governed by Hazelwood School District v. Kuhlmeier. ${ }^{319}$ Under Hazelwood school officials may "exercis[e] editorial control over the style and content of student speech ... so long as their actions are reasonably related to legitimate pedagogical concerns.", 320 This standard still requires school officials to be "viewpoint-neutral." preme Court has said that a school "may not discriminate based on the viewpoint of private persons whose speech it facilitates ...."

312 Hansen v. Ann Arbor Pub. Sch., 293 F. Supp.2d 780 (E.D. Mich. 2003).

313 Id. at 785 .

$314 \mathrm{Id}$. at $790-9 \mathrm{I}$.

315 Id. at 792 .

$316 \mathrm{Id}$.

317 Id. at 793 . For a discussion of government-sponsored speech see infra notes $373-403$ and accompanying text.

318 Hazelwood Sch. Dist. v. Kuhlmeier, 484 U.S. 260, 270-7 I (1988).

319 Hansen, 293 F. Supp. 2d at 795.

320 Haselroood, 484 U.S. at 273.

32 I Hansen, 293 F. Supp. 2d at 797.

322 Rosenberger v. Rector and Visitors of the Univ. of Va., 515 U.S. 819, 834 (1995). 
The school officers in Hansen failed that standard both by restricting Hansen's speech and by excluding traditional Judeo-Christian views from the homosexuality and religion panel:

That Defendants can say with apparent sincerity that they were advancing the goal of promoting "acceptance and tolerance for minority points of view" by their demonstrated in tolerance for a viewpoint that was not consistent with their own is hardly worthy of serious comment. Suffice it to say that inherent in this rationale is the premise that the [plaintiffs'] view of homosexuality as a religious $\sin$ is not a minority view, or at least not a minority view which should be tolerated. It strikes the Court that neither of these premises are pedagogical concerns, but rather are political, cultural or religious, or all three.

The court added that "the record is quite clear that Defendants' [motive] was ... to insure that only one viewpoint was presented by the [homosexuality and religion] panel." ${ }^{324}$

The court properly rejected defendants' argument that tolerating Hansen's statements would have frustrated their effort "'to provide a safe and supportive environment for gay and lesbian students." "Although a school may foster a "safe" environment for all students, the court doubted it is valid to foster a "supportive environment" for homosexual students. The school may foster an equally "supportive environment" for all students, but here the school promoted the view "that homosexuality and religion were not incompatible" and overtly suppressed the view that "homosexuality was sinful." ${ }^{326}$ This position is no more legitimate for public school officials than taking sides in an election, ${ }^{327}$ or, since this case involves religion, endorsing one religion over others.

The court held that defendants had violated plaintiffs' rights under the Free Speech, Equal Protection, and Establishment Clauses ${ }^{328}$ It also denied defendants' claims of qualified immunity from liability because "a reasonable education official in their position would ... have understood

323 Hansen, 293 F. Supp. 2d at $801-02$.

324 Id. at 803 .

$325 \mathrm{Id}$. at 802 .

$326 \mathrm{Id}$. at $8 \mathrm{or}$.

327 In Anderson v. City of Boston, 380 N.E.2d 628 (Mass. 1978), appeal dismissed, 439 U.S. I060 (1979), the Massachusetts Supreme Judicial Court enjoined the city of Boston from spending government money to influence voters to vote for a state constitutional amendment, even though the city argued that it was acting to counter corporate spending on the other side. There seem to be no Supreme Court cases on this issue, but that is only because there have no cases presenting "a clear need for the Court to intervene to establish precise limits on propaganda efforts by government agencies ...." John NowaK, ET al., Constitutional Law \$ I6.II, at II60 (7th ed. 2004).

328 Hansen, 293 F. Supp.2d at 815. 
that their actions were unlawful ...." ${ }^{329}$ Plaintiffs sought only nominal damages, fees and costs, which the court awarded.

In the past, schools have denied claims of parental rights that would impede pro-homosexual school programs. ${ }^{330}$ In one case, the court denied parents access to public schools to witness or record these activities. ${ }^{331}$ This is troubling. In effect, the school not only tells children their parents are wrong if they hold traditional views about homosexuality; it also tells children their religion is wrong if it holds such views. This activity probably does not violate the parents' constitutional rights under current doctrine, but it does violate our prevailing social norms about parental control.

One recent court decision may herald a change in the law here. Montgomery County (Maryland) public schools adopted a curriculum stating: "Religion has often been used to justify hatred and oppression .... Early Christians were not hostile to homosexuals. Intolerance became the dominant attitude only after the Twelfth Century." ${ }^{333}$ The federal district court enjoined use of this curriculum, saying: " $[t]$ he Court does not understand why it is necessary, in attempting to achieve the goal of advocating tolerance and providing health-related information, that defendants must offer up their opinions on such controversial topics as whether homosexuality is a sin, whether AIDS is God's judgment on homosexuals, and whether churches that condemn homosexuality are on theologically solid ground." 334

3. University Speech Codes and Thought Control. ${ }^{335}$-Most American universities now have codes that bar harassment based on, inter alia, race, sex, or sexual orientation. These codes pose no problem if the term "harassment" is properly defined. Unfortunately, most codes are so broad and vague that they can be, and in some cases have been, wielded to punish constitutionally protected speech. When these prosecutions are challenged in court,

329 Id. at 814 .

$33^{\circ}$ One school district denied parents' request for advance notice when the school assigned lessons promoting homosexuality. See Tracy Jan, Parents Rip School over Gay Storybook; Lesson Reignites Clash in Lexington, Boston GloBE, Apr. 20, 2006, available at http://www.boston. $\mathrm{com} /$ news/local/articles/2006/04/20/parents_rip_school_over_gay_storybook/.

331 See Jessica Fargen, Mom Ousted For Taping Gay Acceptance 'Lies', Boston Herald, Dec. I6, 2004 .

332 Parents generally have no right to withdraw their children from school activities that teach children that their religion is wrong. See Mozert v. Hawkins County Bd. of Educ., 827 F.2d 1058 (6th Cir. 1987), cert denied, 525 U.S. 1066 (1988).

333 David French, Expelling God from the University, ACAD. Questions, Summer 2006, at 75,82 .

334 Citizens for a Responsible Curriculum v. Montgomery County Pub. Schs., No. Civ.A. AW-05-1 194, 2005 WL 1075634 (D. Md. May 5, 2005)

335 For an excellent discussion of university speech codes see Silverglate et Al., supra note $29 \mathrm{I}$. 
the victims almost always prevail, but most of these codes remain on the books and exert a chilling effect on students and faculty who might question the politically correct creed on homosexuality. ${ }^{336}$

Some schools claim that they bar only "fighting words," which are not constitutionally protected. However, "fighting words" are narrowly defined not "in terms of what a particular addressee thinks," but as "words likely to cause an average addressee to fight," words that "have [the] characteristic of plainly tending to excite the addressee to a breach of the peace., ${ }^{337}$ They must be words that would objectively tend to provoke a fight and be directed at an individual who reasonably might fight. ${ }^{338}$ Speech cannot be forbidden as "intimidation" unless it conveys a clear threat of bodily harm.

In UWM Post $v$. Board of Regents of the University of Wisconsin System, the university argued in defense of its ban on "racist" speech that it is "understandable to expect a violent response to discriminatory harassment, because such harassment demeans an immutable characteristic which is central to the person's identity." ${ }^{340}$ The court struck down the code. It conceded that some racist statements are fighting words, but not all; the code was unconstitutionally broad. ${ }^{341}$ The "fighting words" justification for academic speech codes has failed in every court in which it has been made.

"Discriminatory harassment" is also not protected by the First Amendment. Indeed federal law requires colleges and universities to prohibit such conduct. ${ }^{343}$ However, many schools cynically distort this law to impose codes that are unnecessarily broad and infringe free speech. Like "fighting words," "discriminatory harassment" is narrowly defined by the Supreme Court. In Davis v. Monroe County Board of Education, the Court said that, in the academic context, harassment must be so "objectively offensive that it effectively bars the victim's access to an educational opportunity or benefit." 344

336 See infra note $353-6 \mathrm{I}$ and accompanying text.

337 Chaplinsky v. New Hampshire, 315 U.S. 568, 573 (1942).

$33^{8}$ See infra note 359 (discussing Brandenbung v. Ohio).

339 Virginia v. Black, 538 U.S. 343 (2003).

340 UWM Post v. Bd. of Regents of the Univ. of Wis. Sys., 774 F. Supp. I I63, I 73 (E.D. Wis. 199I) (quoting Defendant's Combined Brief).

$34 \mathrm{I} I d$.

342 See id; see also Dambrot v. Cent. Mich. Univ., 55 F.3d I I77, 1185 (6th Cir. 1995); Roberts v. Haragan, 346 F. Supp. $2 d$ 853, 872 (N.D. Tex. 2004) (finding that university's speech code 'would suppress substantially more than threats, 'fighting words,' or libelous statements that may be considered constitutionally unprotected speech").

34320 U.S.C. $\S 1681$ (a) prohibits sex discrimination in higher education and in public schools. Moreover, discriminatory harassment on any ground is not protected by the First Amendment, so schools may constitutionally forbid harassment on the basis of sexual orientation.

344 Davis v. Monroe County Bd. of Educ., 526 U.S. 629, 633 (1999). 
The requirement that the conduct be "objectively" offensive is crucial; it means that harassment does not occur simply because a hypersensitive person takes offense, or claims to do so. $^{345}$ Conduct that is merely rude or unpleasant does not meet this test; the "conduct must be extreme ... .$^{346}$ In academia rough debate is allowed, even encouraged. To constitute harassment, speech must be intended solely to harass someone, not to address an academic issue. Even deliberate ridicule of someone's public behavior cannot be treated as harassment. ${ }^{347}$ The Department of Education's Office of Civil Rights has said:

\begin{abstract}
Harassment, ... to be prohibited by the statutes within OCR's jurisdiction, must include something beyond the mere expression of views, words, symbols or thoughts that some person finds offensive. Under OCR's standard, the conduct must also be considered sufficiently serious to deny or limit a student's ability to participate in or benefit from the educational program.
\end{abstract}

The demand that conduct "effectively bar ... the victim's access to an educational opportunity or benefit" is significant. Rarely does a single statement satisfy this condition. Also, to constitute harassment, speech must be directed at an individual, not at a wider group. Even in the more restrictive workplace context, "'mere utterance of an ethnic or racial epithet which engenders offensive feelings" is not harassment. ${ }^{349}$ Conduct that is "merely offensive" is not enough if not severe or pervasive. ${ }^{350}$ In academia, conduct must be "serious enough to have the systemic effect of denying the victim equal access to an educational program or activity."

Because many schools improperly claimed that federal law demands broad speech codes, the Office of Civil Rights ("OCR") for the Department of Education, which administers laws against discriminatory harassment, distributed a letter stating that "OCR's regulations and policies do not require or prescribe speech, conduct, or harassment codes that impair the exercise of rights protected under the First Amendment ...." These

345 The Office of Civil Rights says its "standards require that the conduct be evaluated from the perspective of a reasonable person in the alleged victim's position." Letter from Gerald Reynolds, Assistant Secretary, United States Department of Education's Office for Civil Rights, Department of Education, July 28, 2003, at 2 [hereinafter "OCR Letter"], available at http://www.thefire.org/index.php/article/5046.hml.

346 Faragher v. City of Boca Raton, 524 U.S. 775, 788 ( 1998).

347 See Hustler Magazine v. Falwell, 485 U.S. 46 (1987) (holding a ribald parody consticutionally protected).

348 OCR Letter, supra note 345 , at I-2.

349 Meritor Sav. Bank v. Vinson, 477 U.S. 57, 67 (1986) (quoting Rogers v. EEOC, 454 F.2d 234, $23^{8}$ (5th Cir. 197i)).

350 Harris v. Forklift Sys., Inc., 5 Io U.S. 17,2 I (1993).

35 I Davis v. Monroe Bd. of Educ., 526 U.S. 629, 652 (1999) (emphasis added). 
rules must be applied "in a manner that respects the legal rights of students and faculty, including those court precedents interpreting the concept of free speech." 35

Virtually every university speech code subjected to judicial review has been held unconstitutional. Some, like UWM Post, ${ }^{353}$ found the code too broad in that it forbade protected speech as well as harassment. Others cases found codes to be too vague; one could not determine with reasonable precision what conduct these codes prohibit. As a result, these codes "chilled" free speech; students and scholars had to refrain from protected speech for fear they might be punished. Thus, in Doe v. University of Michigan, ${ }^{354}$ the court struck down a code that prohibited "discrimination and discriminatory harassment" and speech "that stigmatizes or victimizes an individual" or has the "effect of interfering with an individual's academic efforts."

Speech codes have been wielded to silence criticism of homosexuality. William Paterson University, a state school, found a student guilty of discrimination and harassment and punished him for calling homosexuality a "perversion" in a private response to a message from a faculty member announcing the screening and discussion of a film described as "a lesbian relationship story." ${ }^{356}$ The university's action was unconstitutional. Fortunately, it later rescinded the penalty.

Some schools have tried two other ploys to circumvent the First Amendment. One is to label disfavored expression "hate speech." There is no "hate speech" exception to the First Amendment. Unless they constitute fighting words or discriminatory harassment, even explicit expressions of hatred for a person or group are protected speech. ${ }^{358}$ Nor can speech be

352 OCR Letter, supra note 345 , at $\mathbf{I}$.

353 See supra notes $340-42$ and accompanying text.

354 Doe v. Univ. of Mich., 72 I F. Supp. 852 (E.D. Mich. 1989).

355 See also Cohen v. San Bernardino Comm. Coll., 92 F.3d 968 (9th Cir. 1996); Dambror v. Cent. Mich. Univ., 55 F.3d I 77 (6th Cir. 1995); Bair v. Shippensburg Univ., 280 F. Supp.2d 357 (M.D. Pa. 2003); Booher v. Bd. of Regents, 2:96-CV-135, I998 U.S. Dist. LEXIS I 1404 (E.D. Ky. July 22, I998); Roberts v. Haragan, 346 F. Supp. 2d 853 (N.D. Tex. 2004); Corry v. Stanford Univ., No. 740309 (Cal. Super. Feb. 27, 1995). Cf. Saxe v. State Coll. Area Sch. Dist., 240 F.3d 200 (3d Cir. 2001) (high school case).

356 See Press Release, Foundation for Individual Rights in Education ("FIRE"), William Paterson University Tramples Student's Constitutional Rights (July 20, 2005), http://www.thefire.org/index.php/article/61 $19 . \mathrm{html}$. The student's message to the professor asked that he not be sent "any mail about 'Connie and Sally' and 'Adam and Steve ....' These are perversions. The absence of God in higher education brings on confusion. That is why in these classes the Creator of the heavens and the earth is never mentioned." The professor said that the message "sound[ed] threatening." FIRE is assisting the student.

357 See Wayne Parry, 'Harassment' Reprimand Dropped Against College Worker, Associated PRESS, Dec. 7, 2005, available at http:/www.thefire.org/index.php/article/6555.html.

358 See Silverglate ET AL., supra note 291 , at $97-98$. The same would be true of treating protected speech as creating an intentional infliction of emotional distress. See id. at 41-43. 
forbidden for inciting violence "except where such advocacy is directed to inciting or producing imminent lawless action and is likely to incite or produce such action."

The other ploy is to add a clause to a speech code stating that it does not apply to speech protected by the First Amendment. ${ }^{360}$ These "savings" clauses are intended to abort allegations of overbreadth on the theory that a code cannot infringe protected speech if it specifically says that it does not do so. These savings clauses are fatally vague. ${ }^{361}$ Affected persons can't be sure how the First Amendment will apply in many situations, so to avoid trouble, they must refrain from a broad range of speech.

The First Amendment also protects citizens from compelled speech or submission to indoctrination. ${ }^{362}$ Some colleges force students to undergo "diversity" or "sensitivity" training; this has become common in freshman orientation programs. These programs are permitted if they merely inform students about (constitutionally valid) campus rules on harassment. They may be unconstitutional, however, if they "are aimed at forcing students to change their minds or adopt officially sanctioned attitudes." ${ }^{363}$ Also invalid is any requirement that a student approve some statement of beliefs or agree to refrain from constitutionally protected speech.

Speech in the university classroom is treated differently than speech outside it. Colleges may demand a higher degree of civility in the classroom, especially from instructors. ${ }^{365}$ This makes sense. Students in class are a more captive audience than they are outside the classroom. Instructors are paid to teach, which reasonably includes treating students civilly in class. Accordingly, faculty may be held to a higher standard than students, at least in the classroom. Here too, however, a school's power to restrict speech is limited. Hardy $v$. Jefferson Community College ${ }^{366}$ ruled that a college could not fire a professor for making offensive statements about women and minorities that were germane to the subject of the course. And Silva v. University of New Hampshire ${ }^{367}$ held that a university writing teacher could not be fired for sexual harassment simply because he used sexually suggestive phrases in the classroom.

359 Brandenburg v. Ohio, 395 U.S. 444, 447 (1969).

360 See Silvergate et. al., supra note 291 , at 72.

36I See Laurence Tribe, American Constitutional Law $\$$ i $2-29$ (2d ed. i 988 ).

362 See W. Va. State Bd. of Educ. v. Barnette, 319 U.S. 624 (1943) (holding that public school may not compel students to recite the Pledge of Allegiance).

363 Silverglate Et al., supra note 291, at 69.

364 See id. at 142 .

365 See Bonnell v. Lorenzo, 24I F.3d 800 (6th Cir. 2001) (upholding discipline of professor who made offensive classroom remarks about women that were not pertinent to the topic of the course).

366 Hardy v. Jefferson Cmty. Coll., 260 F.3d 67I (6th Cir. 2001).

367 Silva v. Univ. of N.H., 888 F. Supp. 293 (D.N.H. 1994). 
All these principles apply to both sides in the clash between religion and the homosexual movement. Comments for and against religion and comments for and against homosexuality must be treated alike.

\section{Use of University Facilities and School-Subsidized Activities.-In Rosenberger} v. Rector and Visitors of the University of Vinginia, ${ }^{368}$ the university had a system of funding student journals that discussed issues of public interest. The university denied funds to a journal that discussed such issues from religious perspectives, claiming that the denial was mandated by the Establishment Clause or, at least, was within the discretion of the university in deciding what activities to fund. The Supreme Court rejected both arguments. It said a school "may not discriminate based on the viewpoint of private persons whose speech it facilitates ...." ${ }^{369}$ Accordingly, colleges may not discriminate against student groups or activities because they are religiously oriented or take a position on homosexuality of which the administration disapproves. The same is true for the allocation of funds from student activity fees. ${ }^{370}$.

Enforcing religious neutrality is difficult, though; administrators and student governments disbursing school funds and student activity fees have broad discretion in choosing which activities to fund and how much to give them so long as they are not shown to discriminate on the basis of religion or of viewpoint. Even if those distributing funds have a discriminatory motive, proving that motive may be impossible if they are clever enough to offer a legitimate pretext for their discrimination.

Access to facilities presents an easier case. So long as a facility is commonly available for student use and is not already committed, a student group cannot be barred from using the facility on the same terms that apply to other groups.

\section{F. Government Endorsement of Homosexuality}

In the 1998 case of American Family Association, Inc. v. San Francisco, ${ }^{373}$ several religious groups, including plaintiffs, placed a full-page ad in the San Francisco Chronicle as part of a campaign called "Truth in Love." The ad de-

368 Rosenberger v. Rector and Visitors of the Univ. of Va., 515 U.S. 819, 822-26 (1995).

369 Id. at 834 .

370 See Bd. of Regents v. Southworth, 529 U.S. 217 (2000).

37 I Prior to Rosenberger, one lower court case had upheld a claim of non-neutral funding. Gay and Lesbian Students Ass'n v. Gohn, 850 F.2d 361 (8th Cir. 1988). In that case, however, "the record [was] replete with evidence that the [funding body's] action was based on viewpoint discrimination ...." Id. at 366. Since Rosenbenger and Southrorth, funding bodies have apparently been more careful either to be neutral or to disguise their motives.

372 See Widmar v. Vincent, 454 U.S. 263 (1981).

373 Am. Family Ass'n v. San Francisco, 277 F.3d I I 4, I I 18-19 (9th Cir. 2002). 
clared that "Christians love homosexuals, but that "God abhors any form of sexual sin,' whether it is homosexuality, premarital sex or adultery." It said further "we've had a hand extended [,] ... an open hand that offers healing for homosexuals, not harassment," and that Christian groups want to help people to reject self-destructive behavior. ${ }^{374}$

Soon after, the San Francisco Board of Supervisors sent plaintiffs a letter that read:

Supervisor Leslie Katz denounces your hateful rhetoric against gays, lesbians and transgendered people. What happened to Matthew Shepard is in part due to the message being espoused by your groups that gays and lesbians are not worthy of the most basic equal rights and treatment. It is not an exaggeration to say that there is a direct correlation between these acts of discrimination, such as when gays and lesbians are called sinful and when major religious organizations say they can change if they tried, and the horrible crimes committed against gays and lesbians.

The City and County of San Francisco also adopted two resolutions. One condemned the murder of a gay man, Billy Jack Gaither, and "call[ed] for the Religious Right to take accountability for the impact of their longstanding rhetoric denouncing gays and lesbians, which leads to a climate of mistrust and discrimination that can open the door to horrible crimes such as those committed against Mr. Gaither."

The second resolution condemned "anti-gay" television advertisements, specifically mentioning plaintiffs. The resolution said this campaign "promote[s] an agenda which denies basic equal rights for gays and lesbians and routinely state[s] their opposition to toleration of gay and lesbian citizens." Further, "the vast majority of medical, psychological and sociological evidence supports the conclusion that sexual orientation can not be changed" and that contrary statements like those in the Chronicle ad are "erroneous and full of lies." The resolution also said that suggestions that gays or lesbians are "immoral and undesirable create an atmosphere which validates oppression of gays and lesbians" and abets their mistreatment. It then exhorted "local television stations not to broadcast advertising campaigns aimed at 'converting' homosexuals." ${ }^{377}$

Plaintiffs sued, claiming violations of the Free Exercise and Establishment Clauses and a hybrid free exercise-free speech claim. The district court dismissed all claims, and the court of appeals affirmed. Applying the Lemon test ${ }^{378}$ to the Establishment Clause claim, the court found that:

374 Id. at 1119.

375 Id.

376 Id.

377 Id. at 1120.

378 Lemon v. Kurtzman, 403 U.S. 602, 612-13 (1971). 
although the letter and resolutions may appear to contain attacks on the Plaintiffs' religious views, in particular that homosexuality is sinful, there is also a plausible secular purpose in the Defendants' action-protecting gays and lesbians from violence-and that therefore the Plaintiffs could not state a claim under the secular purpose prong.

As to the "primary effect" prong of Lemon, the court said that the statement in the first resolution "calling 'for the Religious Right to take accountability for the impact of their long-standing rhetoric denouncing gays and lesbians' ... appears to be more of an afterthought and any disparagement of the Religious Right is not the primary effect of the resolution." 380 However:

The other resolution and the letter to the Plaintiffs present a closer question. These documents are directly aimed at the Plaintiffs and both documents contain statements from which it may be inferred that the Defendants are hostile towards the religious view that homosexuality is sinful or immoral. Nonetheless, we believe the district court properly concluded that this was not the principal effect of the Defendants' action. The documents, read in context as a whole, are primarily geared toward promoting equality for gays and discouraging violence against them .... [O]ur job is not to question the validity of the Defendants' assumptions or the wisdom of their corresponding actions; rather, it is to determine the constitutionality of those actions. We believe a reasonable, objective observer would view the primary effect of these documents as encouraging equal rights for gays and discouraging hate crimes, and any statements from which disapproval can be inferred only incidental and ancillary.

The court is right that it should not "question the validity of the Defendants' assumptions or the wisdom of their corresponding actions," but it can and should question whether the facts show defendants' sincerity. ${ }^{382}$ The letter and resolutions repeatedly accuse plaintiffs of abetting discrimination and violence against gays even though their ad proclaimed love for homosexuals and called for "healing for homosexuals, not harassment." 383 The ad also expressed a desire to relieve homosexuals from the sexually transmitted diseases (including AIDS) and alcohol and drug abuse that are widespread among them. ${ }^{384}$

379 Am. Family Ass'n, 277 F.3d at 1121.

380 Id. at 1122 .

381 Id. at $1122-23$. The court found that the defendants' action did not create excessive entanglement with religion. $I d$. at 1 I 23.

382 Id. at I 122.

383 Id. at I 119 .

$3^{8} 4$ Id. 
Since defendants' characterization of the plaintiffs is totally at odds with plaintiffs' statements, it is hard to believe that defendants' primary purpose was to protect gays from violence and other harm. Plaintiffs' ads also called adultery a sin, yet defendants did not accuse them of fomenting violence against adulterers, as they presumably would have done if their concern were to protect from violence those whose acts are called sinful. More likely defendants intended to promote the homosexual lifestyle, to curry favor with those who share that goal, and to demonize and intimidate those who disapprove of homosexuality.

American Family Association also raises questions about the meaning of primary purpose and primary effect under Lemon. Virtually any government action intended and effective to promote or inhibit religion will also have a plausible secular purpose and effect. Many atheists concede, for example, that religion has desirable secular effects, like promoting obedience to law. When government is accused of promoting religion, courts often seize on any evidence of an intent to promote religion, or any effect to advance religion, as fatal. ${ }^{385}$ Even assuming that protecting gays from violence and other harm was one goal of defendants in American Family Association, defendants were clearly hostile to plaintiffs' religion and sought to achieve that goal by injuring plaintiffs' reputation and effectiveness. As Judge Noonan said in dissent, a pronouncement by the city simply criticizing violence against gays in general would not have conflicted with the plaintiffs' message of "love for homosexuals." Thus, he continued:

To reach the plaintiffs, to strike at what the city perceived as a danger, the city had to strike at the heart of the plaintiffs' religious belief, to focus on their belief that the conduct they were trying to change was an offense to God and to make that belief responsible for murder.

Defendants denounced plaintiffs for treating homosexuality as "sinful" and exhorted "the Religious Right" to "take accountability" for abetting violence against gays. The majority's characterization of this attack on plaintiffs' faith as "an afterthought" is incredible. As Judge Noonan said, "It is difficult to think of a more direct attack." mandates governmental neutrality between religion and religion, and be-

385 See, e.g., Board of Educ. v. Grumet, 5 I 2 U.S. 687 (1994) (finding that legislature's purpose in creating separate school district was to promote the religion of a small sect dominant in the new district, not to ease intergroup tensions; Court refused to credit claim that legislature would have done the same for a non-religious group); Wallace v. Jaffree, 472 U.S. 38, 47-49 (1985) (finding that legislature's purpose in mandating a moment of silence in public schools was to promote religion); Epperson v. Arkansas, 393 U.S. 97 (I968) (finding that legislature's purpose in banning teaching of evolution in public schools was not to avoid strife but to promote religion).

386 Am. Family Ass'n, 277 F.3d at 1127.

387 Id. at I 126. 
tween religion and nonreligion." ${ }^{388}$ But there is "no neutrality when the government's ostensible object is to take sides." "[L]iberty and social stability demand a religious tolerance that respects the religious views of all citizens ...." ${ }^{390}$ By singling out plaintiffs and "the Religious Right" in its statements, defendants scorned neutrality and took sides on the issue of whether homosexuality is sinful. It is alarming that a government body can wage such a campaign against a religion with impunity.

In their free exercise claim plaintiffs invoked the principle of Church of Lukumi Babalu Aye, Inc v. City of Hialeah that "a law targeting religious beliefs as such is never permissible." ${ }^{391}$ The court in American Family Association found that principle inapplicable because "in this case, there is no actual 'law' at issue." ${ }^{392}$ As in Vernon, ${ }^{393}$ any chilling effect from defendants' actions was insufficient to constitute a violation of free exercise. Limiting the protection of free exercise to formal "laws," however, invites public officials to harass a disfavored faith by other means, as happened here.

Finally, the court rejected plaintiffs' hybrid free exercise and free speech claim. "[T]o make out a hybrid claim, a 'Free Exercise plaintiff must make out a colorable claim that a companion right has been violated." The court denied that defendants had violated plaintiffs' free speech by "prescrib[ing] an orthodoxy of belief on the subject of homosexuality .... [P]ublic officials may criticize practices that they would have no constitutional ability to regulate, so long as there is no actual or threatened imposition of government power or sanction.. ${ }^{395}$ Similarly, the court denied that defendants had engaged in improper viewpoint discrimination because they "have not imposed or even threatened any prohibitions or sanctions for the Plaintiffs' viewpoint." ${ }^{396}$

The court's finding of no "threatened imposition of government power or sanction" is factually dubious. ${ }^{397}$ Defendants urged "local television stations not to broadcast advertising campaigns aimed at 'converting' homo-

388 McCreary County. v. ACLU, 545 U.S. 844, 860 (2005) (quoting Epperson, 393 U.S. at 104); see also Wallace, 472 U.S. at 53; Everson v. Bd. of Educ., 330 U.S. I, 15-16 (1947).

389 MoCreary County, 545 U.S. at 860; see also Corp. of Presiding Bishop v. Amos, 483 U.S. 327,335 (1987) ("Lemon's 'purpose' requirement aims at preventing [government] ... from abandoning neutrality and acting with the intent of promoting a particular point of view in religious matters.").

390 McCreary County, 545 U.S. at 860 (quoting Zelman v. Simmons-Harris, 536 U.S. 639, 718 (2002) (Breyer, J., dissenting)).

391 Church of Lukumi Babalu Aye, Inc v. City of Hialeah, 508 U.S. 520, 533 ( 1993 ).

392 Am. Family Ass'n, 277 F.3d at 1124.

393 See supra notes $191-205$ and accompanying test.

394 Am.Family Ass'n, 277 F.3d at 1 I 24 (quoting Miller v. Reed, I 76 F.3d 1202 , 1207 (9th Cir. 1999)).

395 Id. at $1124-25$.

396 Id. at 1125 .

397 Id. 
sexuals." ${ }^{398}$ As in Okwedy v. Molinari, ${ }^{399}$ television stations would be rash not to treat defendants' statement as a threat to withhold government business and to encourage private entities to do likewise to stations that aired the condemned message. Plaintiffs alleged that stations actually did reject their ads "at least in part because of the resolution of the Defendants." The majority ignored this allegation. Had it not done so, it could hardly have upheld summary judgment.

The court's insistence on such a threat is also doctrinally questionable. The court said all the cases plaintiffs cited "involve conduct beyond mere criticism of speech by a governmental authority," has never said a threat of sanctions is necessary to a free speech claim. Moreover, the court ignored that this case involves religion. ${ }^{402}$ Under this court's standard, a government body can freely denounce a particular religion as false and evil. This certainly flouts the Supreme Court's declaration that "the command of the First Amendment [is] that the Government maintain strict neutrality, neither aiding nor opposing religion."

This free exercise decision is even more troubling than Vernon. Assuming there was real cause for concern about Vernon's job performance, defendants were the only ones who could deal with it. By contrast, defendants' action in American Family Association was unnecessary, even gratuitous; they could have left the response to plaintiffs' campaign to private actions, which the individual defendants could have supported in their individual capacities. Further, defendants in Vernon claimed to care only about Vernon's job performance, not his religious beliefs. By contrast, defendants' action in American Family Association specifically referred to plaintiffs' statements of their beliefs about sin and morality.

Indeed, defendants' resolutions echo such odious vilifications of religion as calling Judaism a "gutter religion." Those who spew such hate speech can embroider their screeds with claims of secular relevance, like charges that Islam is hostile to America and American values. In the Ninth Circuit, it seems, that is enough to constitutionally justify official hate speech against a disfavored group.

398 Id. at 1120.

399 See supra notes 229-34 and accompanying text.

400 Am.Family Ass'n, 277 F.3d at 1127 (Noonan, J., dissenting) (quoting plaintiffs' complaint).

401 Id. at I 124 (majority opinion).

402 Only one case cited by the court involved religion, and in that case the Supreme Court upheld the claim that government had violated the First Amendment. Hurley v. IrishAmerican Gay, Lesbian and Bisexual Group of Boston, Inc., 515 U.S. 557 (I995).

403 Sch. Dist. of Abington Twp. v. Schempp, 374 U.S. 203, 225 ( 1963 ). 


\section{G. Regulation of Expressive Associations}

As shown by Dale and Hurley, ${ }^{404}$ "expressive associations" have a right to communicate their message that may trump laws that hinder that right. There are several questions about the scope of this right. First, what is an "expressive association"? Dale and Hurley were easy cases on this point. The sole purpose of the organization in Hurley was to conduct a parade which the Court recognized was clearly expressive activity. ${ }^{405}$ As for Dale, the Scouts' purpose is to cultivate the habits and morality of children-also clearly expressive activity. The Court gave no general definition of "expressive association." The earlier case of Roberts v. United States Jaycees also offers little guidance. ${ }^{406}$ As one scholar says, "[a]s the doctrine of freedom of association has developed the examples are all the rules we have." ${ }^{407}$

Some lower court cases address the issue. Circle School v. Pippert ${ }^{408}$ held that two private schools with an advertised mission to give students wide freedom of choice in their education were expressive associations. However, Pi Lambda Phi Fraternity v. University of Pittsburgh ${ }^{409}$ held that a fraternity was primarily a social club; it did not qualify as an expressive association by a few minor acts of community service. A subsidiary question is whether a for-profit entity can qualify as an expressive association. Supreme Court decisions do not preclude such status, but so far no court has granted it.

A second question is when a law unconstitutionally interferes with the message of an expressive association. In Board of Directors of Rotary Internationalv. Rotary Club of Duarte, the Supreme Court found that "the evidence fails to demonstrate that admitting women to Rotary Clubs will affect in any significant way the existing members' ability to carry out their various purposes." $"$ By contrast, in Dale the Court found that the forced inclusion of Dale would significantly affect the Boy Scouts' message, but it did not explain why the two cases were different. Presumably the difference is that the position Dale sought as assistant scoutmaster was a leadership position while mere membership in the Jaycees was not."

404 See supra notes $38-50$ and accompanying text.

405 Hurley, 515 U.S. at 574.

406 The Court simply noted that a "'not insubstantial part' of the Jaycees' activities constitutes protected expression on political, economic, cultural, and social affairs." Roberts v. U.S. Jaycees, 468 U.S. 609, 626 (1984).

407 James Mazzone, Freedom's Associations, 77 WASH. L. Rev. 639, 680 (2002).

408 Circle Sch. v. Pippert, 38 I F.3d 172 (3d Cir. 2004).

409 Pi Lambda Phi Fraternity v. Univ. of Pittsburgh, 229 F.3d 435 (3d Cir. 2000).

4 Io Bd. of Dir. of Rotary Int'l v. Rotary Club of Duarte, 48 I U.S. 537, 548 (1987) (internal citations omitted). Similarly, in Roberts $v$. United States Jaycees the Court determined that the Jaycees had "failed to demonstrate ... any serious burden on the male members' freedom of expressive association" from having to comply with the relevant law by admitting women to its membership. Roberts, 468 U.S. at 626.

4I I The Court in Dale did not expressly say that Dale sought a leadership position, but it 
In Chicago Area Council of Boy Scouts of America v. City of Chicago Commission on Human Relations, ${ }^{42}$ the BSA denied G. Keith Richardson a job because he was an avowed homosexual. The court reversed and remanded the Commission's finding that the BSA had violated an ordinance barring discrimination based on sexual orientation because "the Commission has made no specific factual finding as to whether Richardson was seeking a nonexpressive position that does not abridge the Dale decision." seems a sensible synthesis of Dale and Roberts, but it still leaves the difficult line-drawing question of what is an expressive position.

In Gay Rights Coalition of Georgetown University Law Center v. Georgetown University, ${ }^{414}$ a gay student group denied use of school funds and school facilities by Georgetown University, a Catholic institution, sued the school under a law forbidding discrimination by educational institutions on the basis of, inter alia, sexual orientation. ${ }^{415}$ Acknowledging that the university was an expressive association, the court held that the university must grant the gay group equal benefits but need not grant it official recognition since the former did not constitute expression but the latter did.

Neither Hurley nor Dale involved distribution of funds, so Gay Rights Coalition may still be good law despite those later Supreme Court decisions. However, both Hurley and Dale held that the mere inclusion of avowed gays in defendants' activities would impair their message. Granting the Gay Rights Coalition school funds and facilities seems at least as great an intrusion on expression, so the better view is that Gay Rights Coalition is now overruled.

If a law substantially trammels the message of an expressive association, the law cannot apply unless the government shows a compelling interest in its imposition that cannot be achieved by less restrictive means. ${ }^{416}$ Hurley and Dale do not define compelling interest, but they give short shrift to the states' claims, which suggests that the Court did not believe that the state had a plausible case. That seems right if consideration is limited to the tangible stakes; participation in the holiday parade and service as an assistant scoutmaster involved no money and no other apparent material benefits.

referred to the BSA's policy regarding "Scout leaders," Dale, 530 U.S. at 655; and to the "message" sent by "[t]he presence of an avowed homosexual and gay rights activist in an assistant scoutmaster's uniform," id. at 655-56.

412 Chicago Area Council of Boy Scouts of Am. v. City of Chicago Comm'n on Human Relations, 748 N.E.2d 759 (Ill. App. Ct. 2001).

413 Id. at 768.

414 Gay Rights Coal. of Georgetown Univ. Law Ctr. v. Georgetown Univ., 536 A.2d 1 (D.C. 1987 ) (en banc).

415 The ordinance did not exempt religious institutions. Georgetown is not a public university so it is not subject to a First Amendment duty of viewpoint neutrality under Rosenberger and Southroorth. See supra notes 368-72 and accompanying text.

416 See supra note 38 and accompanying text. 
The symbolic importance of those stakes may be high. Irish ethnicity is valued in Boston, and the Boy Scouts are one of America's most revered institutions. Their symbolic importance understandably attracts the government's interest, but government regulation could interfere with the expressive association's very purpose for existing. Forbidding discrimination against homosexuals in a large, lucrative company might be a compelling state interest, but such a company would be unlikely to qualify as an expressive association whose message would be substantially impaired by having to treat homosexuals equally. In other words, it seems unlikely that forbidding discrimination against homosexuals by expressive associations could ever be a compelling state interest.

In Boy Scouts of America v. District of Columbia Commission on Human Rights, ${ }^{417}$ the District of Columbia Human Rights Act ("HRA") forbid discrimination based on, inter alia, sexual orientation in "any place of public accommodation." ${ }^{418}$ In 1992 Roland Pool and Michael Geller were denied positions as scout leaders in the Boy Scouts ("BSA").

Pool and Geller complained to the District of Columbia Department of Human Rights and Minority Business Development, which was later renamed the Office of Human Rights ("OHR"), accusing the BSA of violating the HRA. The OHR upheld these complaints. It distinguished Boy Scouts of America $v$. Dale ${ }^{419}$ on the ground that:

admitting Geller and Pool as leaders would not significantly burden [the BSA's] expression because-unlike the respondent in Dale-neither [Geller nor Pool] was "a gay activist": no evidence suggested that either "would advocate homosexuality as a BSA adult leader" or "would ... send messages about homosexuality or its lifestyle" just by occupying such a position. "Because Mr. Geller and Mr. Pool are not advocating any particular message," the [Commission] concluded, "their inclusion into an adult leadership position would not infringe upon BSA's core message."

Further, rejecting the BSA's own professions, the OHR held that "opposition to homosexuality is not 'the [BSA's] viewpoint.",

The District of Columbia Court of Appeals reversed, holding that this case could not be distinguished from Dale and that application of the HRA here would violate the BSA's right of expressive association. First, the Supreme Court in Dale accepted the BSA's assertion "that it does not want to promote homosexual conduct as a legitimate form of behavior." ${ }^{422}$ The

417 Boy Scouts of Am. v. D.C. Comm'n on Human Rights, 809 A.2d I 92 (D.C. 2002).

418 D.C. CODE \& 2-I 402.3I(a) (2006).

419 Boy Scouts of Am. v. Dale, 530 U.S. 640 (2000).

420 D.C.Comm'n on Human Rights, 809 A.2d at 1196.

$42 \mathrm{I}$ Id. at 1200.

422 Dale, 53 O U.S. at 641 . 
court here said that "[a]bsent a demonstrated change in the Boy Scouts' 'official position' ... nothing in Dale suggests that a different tribunal may consider other evidence and define the [BSA's] viewpoint differently . . .." As to alleged personal differences between complainants here and the respondent in Dale, the court said that the Supreme Court's meaning in calling the latter a "gay activist" was unclear but, "[a]pplying whatever measure of 'activism' the Supreme Court fairly can be said to have intended, Geller and Pool cannot meaningfully be distinguished from Dale."

Although the court reached the right decision, it is unfortunate that it did not issue a more categorical statement about the scope of the right of expressive association. The Supreme Court in Dale demanded "deference to an association's view of what would impair its expression.... That is not to say that an expressive association can erect a shield against antidiscrimination laws simply by asserring that mere acceptance of a member from a particular group would impair its message." 425 The Court apparently means that an association's claim of impaired expression may be rejected only if it is clearly insincere, an obvious sham, a transparent pretext. Otherwise, its own characterization of its viewpoint must be accepted.

Religious organizations and non-profit colleges are generally exempt from federal income taxes. However, in Bob Jones University v. United States, ${ }^{426}$ the Supreme Court upheld revocation of the tax exemption of a religious university because it discriminated on the basis of race in contravention of public policy. The school did not discriminate in its admissions or academic program, but it forbade interracial dating. ${ }^{427}$ Most Americans would not endorse this policy, and the school later retracted the rule. The state could certainly deny the school public funds because of this rule. However, the impact of the dating rule is minor. There is little interracial dating on most campuses, and African-American students have sought and obtained separate housing and social institutions at many colleges. Nonetheless, the Supreme Court found the rule so heinous as to merit denial of a tax exemption, which might threaten the school's survival. ${ }^{428}$

No religious organization or school has lost a tax exemption because of discrimination against homosexuals, but gay activists will push such action if they get a sympathetic White House. In that case, Bob Jones could be distinguished. The Court there found the school's claim for an exemption based on sincere religious beliefs was outweighed by the Government's "fundamental, overriding interest in eradicating racial discrimination in

423 D.C. Comm'n on Human Rights, 809 A.2d at 1202.

424 Id. at 1202

425 Dale, 530 U.S. at 653.

426 Bob Jones Univ. v. United States, 46I U.S. 574 (1983).

427 Id. at $580-8 \mathrm{I}$

428 Id. at 603,605 
education ...." ${ }^{429}$ This conclusion is supported by the unique enormity of racial discrimination in American history and its specific tie to education; keeping African-Americans ignorant was central to their subordination. Discrimination against homosexuals is not of equal magnitude, and it has little to do with discrimination by schools or other tax-exempt institutions. ${ }^{430}$ Accordingly, the balancing that warranted denial of the tax exemption in Bob Jones should favor retention of the exemption in cases involving homosexuality rather than race.

The Supreme Court also construes the Equal Protection Clause to forbid state governments to render "tangible financial aid [which] has a significant tendency to facilitate, reinforce, and support private [racial] discrimination." ${ }^{431}$ Homosexuality is not a suspect class under the Equal Protection Clause, ${ }^{432}$ so this principle does not apply to government aid to organizations that discriminate on that basis.

\section{H. Criminal Law}

1. Federal Law.-Federal law does not define any crime in terms of sexual orientation. Howeverm the Local Law Enforcement Hate Crimes Prevention Act of 2007 is currently pending in the House of Representatives.

429 Id. at 604. The necessity for such a balancing should survive Employment Division v. Smith because the school makes a hybrid claim entailing not only free exercise of religion but also freedom of association. See supra note I 23 and accompanying text (discussing hybrid claims).

430 The theological treatment of homosexuality by traditional religions is socially significant. See infra notes 520-22 and accompanying text. However, in Bob Jones the issue was the school's behavior, not its theology, and presumably that would also be true in future cases. Even Smith protects a church's right to maintain its theology:

[T] he First Amendment obviously excludes all "governmental regulation of beliefs as such." The government may not compel affirmation of religious belief, punish the expression of religious doctrines it believes to be false, impose special disabilities on the basis of religious views or religious status, or lend its power to one or the other side in controversies over religious authority or dogma.

Employment Div. v. Smith, 494 U.S. 872, 877 (1990) (quoting Sherbert v. Verner, 374 U.S. 398, 402 ( 1963$)$ ) (citations omitted).

431 Norwood v. Harrison, 413 U.S. 455, 466 (1973).

432 See Rich v. Sec'y of Army, 735 F.2d 1220, 1229 (10th Cir. 1984); Hatheway v. Sec'y of Army, 641 F.2d 1376, 1382 (9th Cir.), cert. denied, 454 U.S. 864 (1981); DeSantis v. Pac. Tel. \& Tel. Co., 608 F.2d 327, 332 (9th Cir. 1979); NowaK ET AL., supra note 327, \& 14.3, at 702 ("The Court has not found homosexual persons to be a group of persons who require special constitutional protection.").

433 See Under 21 v. Koch, 65 N.Y.2d 344, 364 ( 1985).

434 Local Law Enforcement Hate Crimes Prevention Act of 2007, H.R. 1592, 1 1oth Cong. Identical legislation passed the House of Representatives in September 2005. See Local Law Enforcement Hate Crime's Prevention Act of 2005, S. 1145 , 109th Cong. (2005) 
If it becomes law, this act will allow federal prosecution for crimes based on "actual or perceived" sexual orientation. ${ }^{435}$ It would also affect ${ }^{436}$ the Hate Crimes Statistics Act of 1990, which requires the Federal Bureau of Investigation to report statistics on hate crimes, including "intimidation." 437 If that happens, the FBI could treat a public religious statement calling homosexuality a sin as an act of "intimidation." "Intimidate" means to "make fearful," ${ }^{438}$ and one purpose in calling conduct sinful is to deter that conduct by instilling fear that the conduct displeases God. Unless such statements constitute fighting words, they should be protected by the First Amendment. ${ }^{439}$ However, the law could still have a serious chilling effect since few people are willing to endure a criminal prosecution even if they feel confident of final exoneration. Further, one can never be certain about litigation, so there is always some risk of incurring criminal penalties.

Moreover, for government to declare statements about sin criminal hate speech is important even if no indictment is sought. The homosexual movement seeks to ostracize traditional religion, and government treatment of religious doctrine as hate speech furthers that goal. However, gay activists should consider that hate speech laws can easily be turned against them. Gay activists often vilify traditional religionists as bigots and hate-mongers. ${ }^{440}$ Such condemnations are meant to intimidate, and could be treated as intimidation by law enforcement officials. In this and all culture battles government should not denounce either side as "hate speech" except for specific threats of pending violence.

2. State Lavw.-In Commonwealth v. Marcavage, ${ }^{411}$ five members of Repent America, a Christian group, were arrested after a scuffle with gay activists during Outfest, a homosexual street fair in Philadelphia. ${ }^{442}$ They were charged with misdemeanors for riot, criminal conspiracy, reckless endangerment, possessing an instrument of crime, highway obstruction, failure to disperse, and disorderly conduct. ${ }^{443}$ They were also charged with a felony

(passed as an amendment to Childrens' Safery Act of 2005, H.R. 3132, I09th Cong. (2005)).

435 Local Law Enforcement Hate Crimes Prevention Act of 2007 \&

436 Id. $\$ 8$.

437 Hate Crimes Statistics Act, Pub. L. No. I01-275, 104 Stat. 140 (1990) (codified at 28 U.S.C. $\$ 534$ (2000)).

438 Webster's New Collegiate Dictionary 605 (1975)

439 See supra note 335 .

440 See supra notes $375-77$ and accompanying text.

441 Commonwealth v. Marcavage, CP: 5I-CR-010131 I-2005 (Ct. Com. Pl., Crim. Div., Philadelphia County, Pa. Feb. 17, 2005).

442 Jason McKee, Judge Tosses Charges Against Marcavage, Delaware Countr Daily Times (Philadelphia, Pa.), Feb. I8, 2005, available at http://www.delcotimes.com/site/news. cfm? $\mathrm{BRD}=1675$ \&dept_id $=1817 \mathrm{I}$ \&newsid $=13987075$ \&PAG $=461$ \& $\mathrm{rf}:=9$.

443 Commonwealth v. Marcavage, MC: 5I-CR-10I266I-2004 (Philadelphia County Mun. Ct., Pa. Oct. 11, 2004). 
under Pennsylvania's Ethnic Intimidation Law, which adds penalties to a criminal act deemed a "hate crime." They faced sentences of up to fortyseven years in prison. After seeing a videotape of the arrests, a trial judge dismissed all charges. She said, "We are one of the very few countries that protects unpopular speech .... We cannot stifle speech because we don't want to hear it, or we don't want to hear it now."

The case breaks no new legal ground; it is a routine application of the First Amendment. It is disturbing, however, that if the alleged crimes had not been filmed, defendants might have been convicted and sentenced to draconian jail terms. Moreover, although charges were finally dropped, defendants incurred substantial costs and emotional distress for over four months. They have now sued the authorities who caused their ordeal, ${ }^{445}$ but these suits are hard to win, and even success there would not fully compensate them for all they have suffered. Many civil libertarians oppose hate crime laws precisely because they inevitably lead to such misguided prosecutions. Again, if we are to have laws punishing "hate speech" at all, they must be narrowly drafted to punish only specific threats of pending violence.

\section{Raising Children}

The Constitution gives parents a right to direct the raising of their children so long as the children are not harmed. ${ }^{446}$ Laws that infringe this right are subject to strict scrutiny and upheld only if "narrowly tailored to serve a compelling state interest." ${ }^{447}$ Gay rights and religious freedom can clash when persons with parental responsibilities disagree about the religious training of the child concerning homosexuality. In In re E.L.M.C., an adoptive, custodial mother was sued by her former lesbian lover, who obtained an order from the trial court against exposing the child to "religious upbringing or teaching ... that can be considered homophobic." ${ }^{448}$ The appellate court vacated this order and directed the trial court to restrict the custodial parent's control only to the extent that otherwise "the child's physical health would be endangered or the child's emotional development significantly impaired," as provided by the relevant state statute. ${ }^{449}$ Emotional

444 McKee, supra note 442.

445 Complaint, Startzell v. City of Philadelphia, No. 05-05287 (E.D. Pa. 2005).

446 See Troxel v. Granville, 530 U.S. 57, 66 (2000); Wisconsin v. Yoder, 406 U.S. 205, 23233 (1972).

447 Moriarty v. Bradt, 827 A.2d 203, 214 (N.J. 2003); see also In re E.L.M.C., 100 P.3d 546, 552 (Colo. Ct. App. 2004); Roth v. Weston, 789 A.2d 43 I, 44 I (Conn. 2002); Blixt v. Blixt, 774 N.E.2d 1052, 1059 (Mass. 2002).

448 In re E.L.M.C., 100 P. 3 d at 548

449 Id. at 563-65 (quoting Colo. Rev. Stat. $\$$ I4-10-130(1) (2006)). 
harm could include alienating the child from the non-custodial person with parental responsibilities.

The verbal standard enunciated by the court is wise. Problems arise when, as here, the religious training would be critical of the sexuality of the non-custodial person. Courts need to draw a fine line by allowing such training in general terms while forbidding the personal vilification of the non-custodial person. That distinction is consistent with traditional Christian and Jewish beliefs.

\section{Religious Freedom in Private Organizations}

\section{A. The Private Workplace}

Title VII and statutes in most states forbid religious discrimination in employment. These laws generally require employers to "reasonably accommodate" employees' religious practice or observance. ${ }^{452}$ Under 'Title VII, this duty does not require employers to incur more than de minimis cost, but several states require more. ${ }^{454}$ These statutes may be invoked when an employer demands behavior toward homosexuality that violates an employee's religious beliefs.

1. Bodett v. Coxcom, Inc. ${ }^{455}$-Evelyn Bodett supervised thirteen employees, including Kelly Carson, for Coxcom, Inc. in Phoenix. Carson was openly gay, as Bodett knew. When they began working together Bodett told Carson that homosexuality was against her Christian beliefs. Carson later testified that she did not feel threatened or harassed by this comment. Bodett later reiterated and expanded on these views, and she and Carson prayed together in Bodett's office. Carson said this event "made [her] born again." Carson also attended church with Bodett at least once and attended a Women of Faith Conference with a ticket bought by Bodett.

450 In re E.L.M.C., 100 P.3d at 563-64.

45 I Related issues are adoption by and child custody with homosexuals and gay couples. Although many people take positions on these issues based on their religious beliefs, adoption and custody decisions are made by courts on the basis of the best interests of the child. Consistent with the Establishment Clause, courts should be religiously neutral when making these decisions. These issues are outside the scope of this Article.

452 E.g., 42 U.S.C. \$ $2000 \mathrm{e}(\mathrm{j})$ (2000).

453 See supra note 64 and accompanying text.

454 See Marjorie A. Shields, Annotation, Necessity of, and What Constitutes, Employer's Reasonable Accommodation of Employee's Religious Preference Under State Law, 107 A.L.R.5th 623, § 5 (b) (2003).

455 Bodett v. Coxcom, Inc., 366 F.3d 736 (gth Cir. 2004).

456 Id. at 740

457 Id. at 74 I. 
In 2000, Carson accepted a job offer from Coxcom's Omaha office. Bodett helped Carson get this job by coaching her on interview skills and giving her an excellent review. The new job was a promotion; Carson deemed it "a good opportunity." Carson then told Mireille DeBryucker, Vice President for Customer Care, she was leaving "because she was uncomfortable with the way Bodett had treated her sexuality." She claimed that in a recent performance review Bodett had said "she would be disappointed if Carson were dating another woman, but happy if she were dating a man." 459 She did not tell Bodett these comments made her uncomfortable or file a complaint because "Bodett was her boss and she could not afford to lose her job." 460

DeBryucker discussed this matter with other officers and agreed that the alleged statement violated Coxcom's Harassment Policy, which stated: "No employee shall harass another employee on the basis of race, color, religion, sexual orientation, national origin, age, disability or veteran status." At a meeting Bodett acknowledged the statements and was fired on the spot.

The district court granted Coxcom summary judgment in Bodett's suit alleging religious discrimination in violation of Title VII. The court of appeals affirmed. It noted that a Title VII claim of religious discrimination can be substantiated by showing that other similarly situated employees were treated more favorably. Bodett made no such showing. ${ }^{462}$ Further, Coxcom had a valid nondiscriminatory reason for firing Bodett because her statements that she would be disappointed if Carson were dating another woman "clearly fall within the gambit [sic] of harassment." ${ }^{463}$ Bodett's claim of discrimination because she was fired without first receiving a warning was also rejected; "under Cox's policy there are circumstances where an employee could be fired without prior warning even though the usual process involved a warning."

The decision is troubling in several respects. First, Coxcom's policy did not forbid all harassment, only harassment on certain bases. Most of the listed bases are not problematic, but the inclusion of sexual orientation gives pause. In the court's account, Bodett never said a word about Carson's sexual orientation; she only commented on Carson's sexual conduct. $^{465}$ If Coxcom construed its policy to include sexual conduct, Bodett at

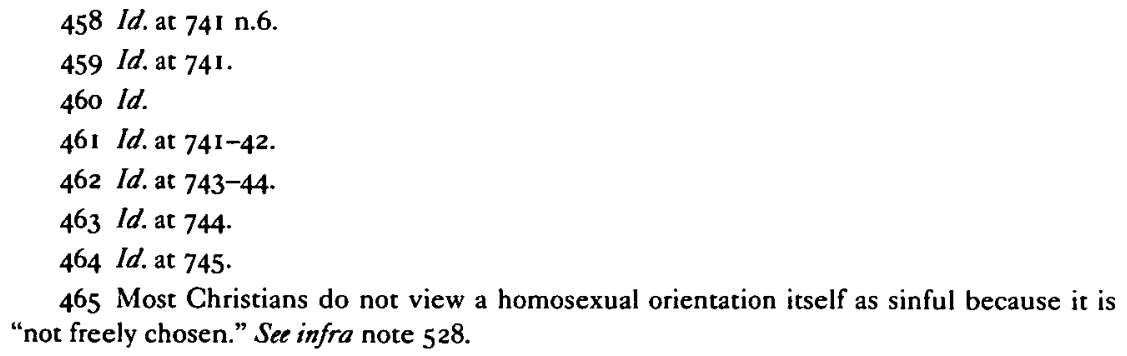


least deserved notice of that fact. Second, if the policy is so construed, that is cause for concern. Most religions have moral codes that include sexual conduct. Thus Coxcom's policy, while tolerating most forms of harassment, forbids one form of harassment that has religious connections. This raises a question whether such a policy in practice discriminates against religion.

Third, the case raises questions about the meaning of harassment. Neither Coxcom nor the court offered a definition. Bodett said she could tell that one of her comments in the performance review made Carson "uncomfortable," ${ }^{466}$ but surely that is not enough. Reasonable comments in ordinary discourse often make someone "uncomfortable." The court's opinion here makes me uncomfortable on the basis of religion, but that does not make it an act of harassment. Further, Bodett and Carson had prayed and attended church together and Bodett had paid for Carson to attend a conference and helped her get a promotion. Bodett reasonably thought that she and Carson were friends. This also puts the instance of Carson's discomfort in perspective; one element of friendship is the freedom to say things that a stranger cannot say because they make the friend uncomfortable. Bodett had no reason to think her comments were harassment.

Fourth, Carson said she did not tell Bodett of her discomfort or file a complaint because "Bodett was her boss and she could not afford to lose her job." ${ }^{467}$ However, Carson never alleged that Bodett had ever mistreated or discriminated against her or even hinted at doing so. On the contrary, she admitted that Bodett had helped her win the promotion and was friendly to her. ${ }^{468}$ This suggests that Carson merely feigned friendship with her supervisor Bodett until she had wheedled from Bodett all she could get, then maliciously charged her with harassment because she hated Bodett, Bodett's faith, or both. In short, Carson's only possible basis for fear of mistreatment was her knowledge of Bodett's religious faith. But she and others could have known of that without any comments by Bodett. Thus the case raises the disturbing prospect that adherence to a faith that disapproves of homosexuality may itself constitute harassment. Thus employees of firms with policies like Coxcom's might feel constrained to hide their faith in order to avoid termination for harassment.

Also troubling is the court's curt dismissal of Bodett's objection to being fired without first getting a warning. The court conceded that a warning was the "usual" practice but said there were exceptions to this practice. ${ }^{469}$ Given the uncertainty about the meaning of "harassment" in Coxcom's policy; Bodett's unblemished record as a Coxcom employee for eighteen years; and the total lack of notice to Bodett that Carson felt harassed by Bodett's statements, Bodett deserved a warning if Coxcom's officers had

466 Bodett, 366 F.3d at 745 .

467 Id. at $74 \mathrm{I}$.

468 See supra note $45^{8}$ and accompanying text.

469 See supra note 464 and accompanying text. 
acted in good faith. Their failure to issue a warning evinces callousness if not animosity which may have been directed at Bodett's religious faith, as her suit contended.

2. Peterson v. Hewlett-Packard. ${ }^{470}$-Hewlett-Packard Co. ("HP") displayed five "diversity posters" in its Boise facility. Each poster showed an HP employee above the caption "Black," "Blonde," "Old," "Gay," or "Hispanic."A second set of posters showed the same five employees and gave a profile of the person and the slogan "Diversity is Our Strength." Richard Peterson, an HP employee in Boise and a devout Christian, responded to this campaign by posting in his work cubicle three passages from the Bible, some of which condemned homosexuality. These postings were visible to persons walking in the adjacent corridor.

HP officers removed these passages under HP's harassment policy, which said: "Any comments or conduct relating to a person's race, gender, religion, disability, age, sexual orientation or ethnic background that fail to respect the dignity and feeling [sic] of the individual are unacceptable." ${ }^{472}$ When Peterson put the passages back up and refused to remove them, he was fired. ${ }^{473}$ Peterson sued HP under Title VII, claiming religious discrimination both by disparate treatment and failure to accommodate. The district court granted HP summary judgment, ${ }^{474}$ and the court of appeals affirmed. ${ }^{475}$

Peterson claimed disparate treatment because HP's posters made him as "uncomfortable" as the biblical passages made some others feel. ${ }^{476}$ The court said HP's posters were different because they were "intended to promote tolerance of diversity . ..." ${ }^{477}$ Peterson also noted that others were allowed to post religious and secular messages and symbols in their work spaces and that a network group of homosexual employees were permitted to advertise in HP's email and newsletter. The court said these were different because they were not intended to be "hurtful." ${ }^{478}$ Peterson, by

470 Peterson v. Hewlett-Packard Co., 358 F.3d 599 (9th Cir. 2004).

$47 \mathrm{I} \mathrm{Id}$. at 601 . The passages were from 2 Corinthians $10: 12$ (which does not refer specifically to homosexuality); Isaiah 3:9 ("[T]hey declare their sin as Sodom, they hide it not. Woe unto their soul! For they have rewarded evil unto themselves."); and Leviticus 20:13 ("If a man also lie with mankind, as he lieth with a woman, both of them have committed an abomination; they shall surely be put to death; their blood shall be put upon them."). Peterson, $35^{8} \mathrm{~F} .3 \mathrm{~d}$ at $60 \mathrm{I}-02$.

472 Id. at 602 .

473 Id.

474 Id.

475 Id. at 608

476 Id. at 604 .

477 Id. at 605 .

478 Id. 
contrast, was "attempting to generate a hostile and intolerant work environment," and his postings were "demeaning and degrading."

The court also denied Peterson's claim of failure to accommodate. He refused to remove the biblical passages unless HP removed its "Gay" poster. An employer need not grant an accommodation that imposes "an undue hardship." due hardship" for HP "because it would have inhibited its efforts to attract and retain a qualified, diverse workforce, which the company reasonably views as vital to its commercial success .... [I]t would have infringed upon the company's right to promote diversity and encourage tolerance and good will among its workforce." result in discrimination against his co-workers or deprive them of contractual or other statutory rights." ${ }^{482}$ The court added that an accommodation does not create undue hardship "merely because the employee's co-workers find his conduct irritating or unwelcome," $" 484$ but the employer need not allow actions "that demean or degrade ...."

The opinion in Peterson is as deplorable as that in Bodett. As in Bodett, despite its references to discrimination and to Peterson as "attempting to generate a hostile and intolerant work environment," ${ }^{855}$ the court never says Peterson actually discriminated against or was hostile or intolerant to any co-worker. As a devout Christian, he probably tried to treat all fellow humans with love. In a poor choice of words, Peterson said the Bible passages were "intended to be hurtful." ignored its context. Peterson promptly added, "the reason [they were] intended to be hurtful is you cannot have correction unless people are faced with the truth." ${ }^{487}$ Like Evelyn Bodett, Peterson sought not to injure fellow workers but, as he saw it, to help them to the path of salvation.

There are some differences in the two cases, though. First, the court in Peterson did not even acknowledge the contradiction in HP's policy "to promote diversity and encourage tolerance and good will among its employees" by silencing and tacitly condemning the many Americans who are traditional Christians, Jews, and Moslems. Second, Peterson's acts were arguably lower key and, therefore, less objectionable than Evelyn Bodett's. Peterson was not a supervisor; he had no control he could wield to intimidate fellow workers. And he did not voice his views to anyone but merely

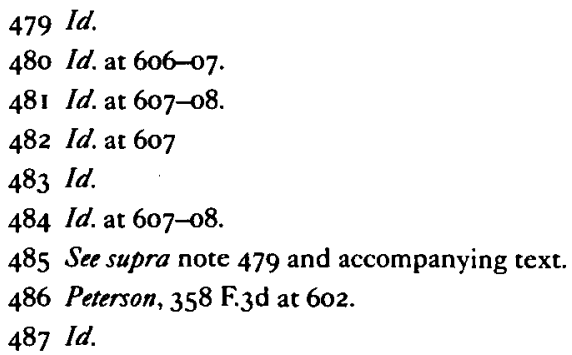


posted them in his own cubicle; they could be completely ignored by others.

Third, unlike the employer in Bodett, HP forbade not only harassment but "[a]ny comments or conduct relating to a person's race, gender, religion, or ethnic background that fail to respect the dignity and feeling of the individual." A duty to "respect" goes far beyond a duty to tolerate. Further, Peterson posted biblical passages in his cubicle in response to HP's "Gay" poster. The court said that "an employee's opposition to a policy of his employer or his advocacy regarding a controversial public issue invokes different considerations than his expressive activity intended to demean or degrade co-workers." ${ }^{489}$ This suggests that an employer may forbid workers to reveal in any way that they are traditional Jews, Moslems, or Christians since those faiths do not "respect" homosexuality. An employee might fear that posting the Ten Commandments in his personal area could be taken to "demean and degrade" atheists and polytheists (like Hindus) because of the commandment "Thou shalt have no other gods before me."

3. Buonanno v. AT\&T Broadband. ${ }^{491}$-AT\&T Broadband fired Albert Buonanno when he refused to pledge to comply with the employer's diversity policy, which stated a "goal to build an environment that ... respects and values individual differences." ${ }^{492}$ Buonanno agreed not to discriminate, but "he believed that some behavior and beliefs were deemed sinful by Scripture, and thus, that he could not 'value' that is hold in esteem or ascribe worth to such behavior or beliefs without compromising his own religious beliefs." ${ }^{493}$ Unsure of the meaning of the policy, he asked for clarification whether it "would require him to value, for example, a 'neo-Nazi skinhead's' beliefs." ${ }^{494}$ The company's Human Resources Manager "refused to engage in what she characterized as a 'philosophical debate"' and fired him."

Buonanno sued, claiming that AT\&T Broadband failed to reasonably accommodate his religious beliefs as required by Tirle VII. The court acknowledged that an employer need not grant an accommodation that causes "undue hardship." ${ }^{496}$ Here, though, "requiring all employees company-wide to "fully recognize, respect and value that there are differences

$488 \mathrm{Id}$. (emphasis added). A similar policy was imposed in Buonanno v. AT\&T Broadband. See infra notes $491-97$ and accompanying text.

489 Peterson, 358 F.3d at 605 n.5.

490 Exodus 20:3 (King James Version).

49I Buonanno v. AT\&T Broadband, LLC, 313 F. Supp. 2d 1069 (D. Colo. 2004).

492 Id. at 1074.

493 Id. at 1075 .

494 Id. at 1076.

495 Id.

$496 I d$. at 1080 (citing Thomas v. Nat'l Ass'n of Letter Carriers, 255 F.3d I I 49, I 156 ( Ioth Cir. 2000)). 
among all of us' would have 'accomplished [AT\&T's] goals' as set forth in the Diversity Philosophy, without imposing any apparent hardship on AT\&T." ${ }^{497}$ Accordingly, the court ruled for Buonanno. This result is reasonable both as public policy and as an interpretation of Title VII. It is only disturbing that a branch of AT\&T, a large, sophisticated company that does business with millions of Americans, had to be dragged into a federal court and told that it is legally obliged to offer such a minimal accommodation.

4. Bruff v. North Mississippi Health Services, Inc. ("NMHS"). ${ }^{498}-$ Sandra Bruff, a counselor for NMHS, refused to counsel a lesbian on her relationship with her female partner because to do so would violate her religious beliefs. She asked not to be assigned cases involving homosexuals or individuals having extramarital affairs. The defendant refused and offered her a transfer, which she declined. She was then fired. The court affirmed dismissal of her claim that NMHS violated its duty under Title VII to accommodate her religion. The court accepted the claim of NMHS that accommodating Bruff would "involve more than de minimis cost," all Title VII requires. The court cired as relevant facts the plaintiff's lack of flexibility, "the [small] size of the [employer's] staff, the area covered by the program and the travel involved, and the nature of psychological counseling incorporating trust relationships developed over time." these facts, the holding seems correct. However, it is troubling that religious discrimination can be excused by de minimis cost when other forms of discrimination require much higher standards of justification.

\section{B. Private Colleges and Universities}

The First Amendment governs only state action; it does not cover private colleges and universities. There are, however, some limits on their ability to suppress speech. First, tort and contract principles may require them to honor representations in, for instance, policy statements or recruitment materials that the school respects free expression. ${ }^{502}$ Second, California has

497 Id. at 1083 .

498 Bruff v. N. Miss. Health Servs., Inc., 244 F.3d 495 (5th Cir. 200I).

499 Id. at $50 \mathrm{I}$.

$500 \mathrm{Id}$.

501 An employer may use practices that have a "disparate impact" on a protected group only if "the challenged practice is job related for the position in question and consistent with business necessity ...." 42 U.S.C. $\$ 2000 e-2(k)(1)(A)(i)$ (2000). The employer's defense that accommodation would impose more than de minimis cost and, thus, "undue hardship," applies only to practices having a disparate impact on religion. Id. $\S 2000($ j).

502 See Silverglate et al., supra note 291, at 54-57; Rehor v. Case W. Reserve Univ., 331 N.E.2d 416, 420 (Ohio 1975) ("a university's policies, rules and regulations relating to faculty members become a part of the employment contract as a matter of law"). 
enacted the Leonard Law, ${ }^{503}$ which extends the First Amendment right of free speech to private colleges and universities. Free speech is essential to every institution of higher education. Congress has imposed many rules on educational institutions that receive federal money. It should also require those institutions to respect free speech.

\section{Resolving the Conflict}

\section{A. General Principles}

Liberal principles demand some tolerance for both religion and homosexuality. Both entail behavior that inflicts no immediate, direct, conventional harm to others. Both sides, then, should be deemed "worthy of respect." However, general liberal principles cannot resolve the conflict between the gay movement and religious freedom. Comprehensive norms like "do unto others as you would have them do unto you," ${ }_{505}^{505}$ Kant's categorical imperative, ${ }_{506}$ and Rawls's social contract, ${ }^{507}$ are too vague to strike a precise balance between valid competing interests.

Nor does the principle of equality help. It requires that likes be treated alike, but it does not tell us what things are alike. ${ }^{508}$ Some sexual acts (like rape and pederasty) deserve no respect. Even if homosexuality warrants some respect, it may be less worthy than some other conditions and conduct that our society protects. For example, many people believe that race generally or African-Americans specifically are a category entitled to special treatment. ${ }^{509}$ The principle of equality also cannot resolve conflicts be-

503 CAL. Educ. Code $\& 94367$ (West 2006).

504 Michael W. McConnell, What Would It Mean to Have a "First Amendment" for Sexual Orientation?, in Sexual Orientation \& Human Rights in American Religious Discourse 234, 235 (Saul M. Olyan \& Martha C. Nussbaum eds., 1998).

505 See Matthewo 7:12 ("Therefore all things whatsoever ye would that men should do to you, do ye even so to them....").

506 "The general formula of the categorical imperative is to act only according to those maxims that can be consistently willed as a universal law ...." The Cambridge Dictionary of PhilosopHy 403 (Robert Audi ed., 1995).This requires that we "respect and fulfill the freedom of all rational beings." Id.

507 John Rawls, A TheORY Of JUSTICE (1971).

508 See Peter Westen, The Empty Idea of Equality, 95 HaRv. L. Rev. 537 (1982): see also NowaK ET AL., supra note 327, at 526 ("Equal protection is the guarantee that similar people will be dealt with in a similar manner .... In reviewing any classification it must be determined whether or not the persons classified by the law for different treatment are in fact 'dissimilar.").

509 See Chai R. Feldblum, Rectifying the Tilt: Equality Lessons from Religion, Disability, Sexual Orientation, and Transgender, 54 ME. L. REv. 160, $188-89$ (2002). Race is treated specially under the Equal Protection Clause. See NowaK ET AL., supra note 327, \& 14.8, at 580 (stating that racial discrimination by government "run[s] counter to the fundamental goal of racial equality, which the Supreme Court has come to recognize as a core value of both the equal 
tween one group's desire for freedom of action and another group's desire for freedom from discrimination or offense. To reconcile this clash, then, requires weighing the relative merits of religious freedom and homosexual conduct.

\section{B. The Case For (and Against) Laws Supporting Homosexuality}

For nearly 3,000 years, Western civilization generally condemned homosexual acts. ${ }^{511}$ Sodomy was often a crime, sometimes a capital offense. In the United States, criminal sodomy laws disappeared only with the recent Supreme Court decision in Larerence $v$. Texas. ${ }^{\text {slz }}$ Many people now consider homosexuality morally equal to heterosexuality, and many American jurisdictions and institutions forbid discrimination based on sexual orientation. Still, there are valid reasons for caution about gay rights.

Some equate disapproval of homosexuality with racism and predict that, like racism, it will soon dissipate, but race and homosexuality are very different. Racial segregation and discrimination have for some time been condemned (at least officially, if not in practice) in most of the world. ${ }^{513}$ Because of America's history of slavery and Jim Crow racial oppression, race has long been considered a special category in American law. ${ }^{514}$ Some Americans still do not believe in racial equality, but few are willing to voice their disbelief openly.

By contrast, many thoughtful people still consider homosexuality immoral or psychologically disordered. Homosexuality is not condoned in much of the world; indeed, it is severely condemned and punished in many nations. ${ }^{515}$ Although homosexuals have often been, and still are, abused in

protection clause of the Fourteenth Amendment and the equal protection component of the Fifth Amendment due process clause").

510 See Feldblum, supra note 509, at $188-89$ (stating that resolving demands for accommodation and freedom from discrimination requires moral judgment calls).

5 II See supra note 2 and accompanying text.

512 Lawrence v. Texas, 539 U.S. 558 (2003).

513 Universal Declaration of Human Rights, G.A. Res. 2 I 7 A (III), Article 2, U.N. GAOR, 3d Sess., Ist plen. mtg., U.N. Doc. A/8 ro (Dec. 12, 1948), states: "Everyone is entitled to all rights and freedoms set forth in this Declaration, without distinction of any kind, such as race ..."

514 See Loving v. Virginia, 388 U.S. I, I0-12 (1967) (noting that race is the evil that prompted adoption of the Equal Protection clause of the Fourteenth Amendment and that race is its primary concern).

515 See Clare Nullis, South Africans OK Bill Recognizing Gay Unions, Plain Dealer, Nov. 15 , 2006, at $\mathrm{A}_{4}$ (stating that homosexuality is illegal in most of sub-Saharan Africa). Sexual orientation is not a forbidden basis of discrimination in the Universal Declaration of Human Rights, and the United Nations Commission on Human Rights has repeatedly refused even to discuss such discrimination. See Andrew Osborn, Muslim Alliance Derails UN's Gay Rights Resolution, Guardian (London), Apr. 25, 2003, http://www.guardian.co.uk/gayrights/story/o,,943222,00. $\mathrm{html}$. The refusal came despite reports of widespread discrimination against homosexuals. See 
America, this mistreatment does not approach the cruelty done to AfricanAmericans. ${ }^{516}$ While most Americans now agree that sodomy should not be a crime, recent elections show that most Americans do not consider homosexuality morally equal to heterosexuality.

Racism violates Christian and Jewish tenets that molded Western philosophy. ${ }^{518}$ The Abolition and Civil Rights Movements appealed above all to Americans' religious beliefs. ${ }^{519}$ By contrast, Christianity and Judaism have long censured homosexual acts. The African-American clergy, which spearheaded the Civil Rights Movement, opposes much of the gay movement. ${ }^{520}$ Some Christian and Jewish organizations now condone homosexuality, but many others do not and are unlikely to do so in this century, if ever. Moreover, traditionalist congregations are growing while liberal congregations are shrinking. ${ }^{521}$ Religious and foreign opposition to the gay movement can combine to influence American events. When the American Episcopal Church installed an actively gay bishop, African churches led the international Anglican Communion to criticize this act and to induce the American bishops to modify their position.

International Commission of Jurists and International Federation for Human Rights Leagues, Joint Oral Statement Mar. 21, 2005. The Supreme Court has noted that "[p]roscriptions against [homosexual] conduct have ancient roots" and that "[s]odomy was a criminal offense at common law and was forbidden by the laws of the original i 3 States." Bowers v. Hardwick, 478 U.S. I 86, 192 (1986), overruled by Lawrence v. Texas, 539 U.S. $55^{8}$ (2003). In his concurrence in Bowers, Chief Justice Burger added that "[h]omosexual sodomy was a capital crime under Roman law" and had long been a serious crime in English law. Id. at 196-97 (Burger, C.J., concurring).

516 For example, African-Americans have below average incomes, which is not true of homosexuals. See supra note 7 and accompanying text.

517 See Alan Wolfe, One Nation, After All 72-76 (1998) (noting that seventy percent of those questioned in a survey condemned homosexuality). Wolfe found the dominant attitude to be: "if what they're asking for is for me, Mr. Average American, to say yes, your life style is the moral equivalent of mine, that I'm not willing to do." Carey Goldberg, Acceptance of Gay Men and Lesbians Is Growing, Study Says, N.Y. Times, May 3 I, 1998, at AI 5. The National Gay and Lesbian Task Force found that "disapproval of homosexuality ... was still 56 percent in $1996 . "$ Id.

518 For example, St. Paul said that in Christianity "there is neither Greek nor Jew, ... Barbarian, Scythian, bond nor free; but Christ is all, and in all." Colossians 3: 1 I.

519 See Rodney Stark, For the Glory of God: How Monotheism Led to Reformations, ScIence, Witch-Hunts, AND the End of Slavery 338-59 (2003) (chronicling the role of religion in the abolition movement); Stephen L. Carter, The Culture of Disbelief: How american law and Politics Trivialize Religious Devotion 227-29 (1993) (describing the importance of religion in the civil rights movement).

520 See Lena Williams, Blacks Rejecting Gay Rights As a Battle Equal to Theirs, N.Y. TimEs, June 28, 1993, at AI.

52 I See, e.g., David Shiflett, Exodus: Why Americans Are Fleeing Liberal Churches for Conservative Christianity (2005).

522 See Laurie Goodstein, Conservative Anglican Leaders Wam of a Schism, N.Y. Times, July 24, 2003 , at AI 2. 
Disapproval of homosexuality is not irrational bigotry. Most adults are instinctively sexually attracted to members of the other sex and not to members of their own sex. Because of reproduction, there are compelling evolutionary reasons for this attitude. Some heterosexual acts are also nonreproductive, but few heterosexuals completely eschew heterosexual intercourse, as homosexuals do. Most people are repelled by homosexuality. Given its propensity to transmit disease, this revulsion, too, makes biological sense. This makes it unlikely that distaste for homosexuality will soon vanish.

Laws promoting acceptance of homosexuality are also less needed than laws promoting racial harmony. Discrimination against gays is not uncommon, but it is hardly pervasive; ${ }^{523}$ it varies by location and industry and is rare in many places and fields where gays live and work.

There is disagreement about whether homosexuality is voluntary. ${ }^{524}$ Some believe it is determined at birth or in early childhood and that, as with race or gender, it is wrong to discriminate against people for a status over which they have no control. ${ }^{525}$ There is strong evidence that homosexual inclinations are deeply ingrained in many gays, but the causes of homosexuality are uncertain and some people are more bisexual; ${ }^{526}$ their sexual choices are more voluntary. And, even if sexual preference cannot

523 See Duncan, supra note 7, at 409 n.55 (citing studies showing fairly low rates of complaints by gays of employment discrimination); William B. Turner, "The Gay Rights State": Wisconsin's Pioneering Legislation to Prohibit Discrimination Based on Sexual Orientation, 2007 WIS. Women's L.J. 40 (forthcoming 2007) (manuscript, on file with the author) (stating that the "total number of complaints claiming sexual-orientation discrimination has apparently always been smal!" under Wisconsin's law broadly banning such discrimination).

524 Some believe that a homosexual orientation is mutable, at least in some cases where the individual wants to change it. See Liberty Counsel and Parents and Friends of Ex-Gays and Gays Launch the "Change Is Possible Campaign," available at www.lc.org. Some homosexual activists also believe that homosexuality can be chosen. See Cheshire Calhoun, Feminism, the Family, and the Politics of the Closet: Lesbian and Gay Displacement (2000); Claudia CARD, Lesbian Choices ( (1995). Moreover, many who experience homosexual desire can also enjoy heterosexual activity. See Janet Shibley Hyde \& John D. Delamater, Understanding Human Sexuality 395-96 (7th ed. 2000) (stating that based on "identity" statistics, there were roughly twice as many heterosexual males as bisexual males, but based upon past sexual "partner" statistics since the age of eighteen, there were four times as many males with both same- and opposite-sex partners as males with exclusively same-sex partners).

525 See supra notes 508-09 and accompanying text.

526 Sexual orientation is not bipolar but ranges from strong heterosexual orientation through neutrality to strong homosexual orientation. See Alan P. Bell \& Martin S. Weinberg, Homosexualities: A Study of Diversity Among Men and Women 53-61 (1978); Richard C. Friedman, Male Homosexuality: A Contemporary Psychonnalytic Perspective 3 (ig88); Alfred C. Kinsey et al., Sexual Behavior in the Human Male 638-4I (1948). Further, "it is certain that - often, if not always-the postnatal environment influences sexual orientation." E.L. Pattullo, Straight Talk About Gays, Comment., Dec. 1992, at 23. Thus homosexual behavior is more common in cultures that approve it than in those that do not. See I ENCYCLOPEDIA OF Homosexuality 578-80 (Wayne R. Dynes ed., I990); Richard A. Posner, Sex and Reason II 7 (1992). 
be altered, public behavior can be; people can be encouraged to keep their sex lives private.

Many religions hold that all are tempted to sin and all sometimes succumb to that temptation. ${ }^{527}$ However, the temptation itself is not a sin, and sins can be forgiven if one truly repents and atones. The National Conference of Catholic Bishops, for example, declares that "homosexuality 'is not freely chosen' and, therefore, 'is not sinful." "528 Homosexual acts, however, are voluntary and are a sin. Homosexuality is not unique in this regard; desire and action are treated the same way with respect to other sins, such as adultery. ${ }^{529}$ If gays are exhorted to chastity, that is not unique. In many religions, a married person whose spouse is absent or sexually incapacitated is enjoined to chastity, possibly for life.

Although behavior-based discrimination is generally not illegal, gay activists argue for special treatment of homosexuality because it is part of one's core identity, the suppression of which inflicts terrible emotional damage. William Eskridge says that "[i]n this century, sexual orientation has replaced religion as a key element of personal identity that situates that person within society." ${ }^{530}$ This claim is hard to test or even to categorize: is it a scientific, a social, or a metaphysical claim? Traditional concepts of human nature, human personality, and human flourishing gave little weight to sexual identity, either in the West or elsewhere. Homosexuality is not the only sexual conduct that has been suppressed; divorce, adultery and incest have often been and still are discouraged or forbidden despite the emotional pain these taboos can exact. Further, whatever benefits are generated by antidiscrimination laws and state approval must be balanced against their detriments.

527 See Romans 3:23 ("For all have sinned.").

528 See Don Lattin, U.S. Catholic Bishops Says Homosexuality Isn't a Sin, S.F. Chron., Nov. 15, 1990, at AI.

529 Some gays object that traditional sects discriminate against them because heterosexuals can marry and have sex, but homosexual acts are never allowed. This is partly true. First, the ban on homosexual acts is not unique. Some other sex acts are categorically forbidden, such as incest, masturbation, bestiality, and pederasty. Adultery is different because it presumes one can enjoy sex within a lawful (i.e., heterosexual) marriage. However, that is cold comfort to someone who is not sexually attracted to his or her spouse but to another person. And many sects forbid or severely restrict divorce, so that a miserable (heterosexual) marriage is a life sentence.

530 William N. Eskridge, Jr., Gaylaw: Challenging the Apartheid of the Closet 293 (1999). The court in Harperv. Poway Unified School District upheld the school's ban on criticism "on the basis of a core identifying characteristic, ... such as race, religion, and sexual orientation." Harper v. Poway Unified Sch. Dist., 445 F.3d I 166, I $182-83$ (9th Cir. 2006). see supra notes 292-308 and accompanying text.

531 See infra notes $523-53$ and accompanying text. 


\section{The Case For (and Against) Religious Freedom}

If gay rights laws are enacted, does religious belief warrant some exemption from these laws? Many other types of antidiscrimination laws provide some religious exemption. This accommodation reduces strife. Religionists forbidden to act according to their faith may protest or defy authority, verbally or physically. Such strife should be avoided unless the cost of accommodation is high.

However, for the Founders, avoiding civil strife was not the only or even the primary justification for religious freedom; ${ }^{532}$ they deemed religious freedom intrinsically important. Thomas Jefferson called "the constitutional freedom of religion the most inalienable and sacred of all human rights. ${ }^{, 533}$ James Madison declared:

It is the dury of every man to render to the Creator such homage, and such only, as he believes to be acceptable to him. This duty is precedent both in order of time and degree of obligation, to the claims of Civil Society .... We maintain therefore that in matters of Religion, no man's right is abridged by the institution of Civil Society, and that Religion is wholly exempt from its cognizance.

Thus "the Founders granted religion a special status in the Constitution. This status derived from a conviction that religious exercise, as opposed to other personal and social forces, needed and deserved unique treatment.". 535

The words of Jefferson and Madison may trouble secularists. Calling religious freedom "sacred" and referring to "the Creator" posits the existence of God, which is to assume the answer to the question that divides believers from agnostics and atheists. That assumption seems to violate the taboo against establishing religion. ${ }^{536}$ However, even most secularists

532 See Steven D. Smith, The Rise and Fall of Religious Freedom in Constitutional Discourse, 140 U. PA. L. REv. 149, 163-65 (1991).

533 Thomas Jefferson, Freedom of Religion at the University of Virginia, in The Complete Jefferson 957, 958 (Saul K. Padover ed., I 969).

534 James Madison, Memorial and Remonstrance Against Religious Assessments, reprinted in The Supreme Court on Church and State 18-19 (Robert S. Alley ed., 1988).

535 Arlin M. Adams \& Charles J. Emmerich, a Nation Dedicated to Religious Liberty: The Constitutional Heritage of the Religion Clauses 9i (1990); see also John Garvey, What Are Freedoms For? 49-57 ( 1996); TRIBE, supra note 36I, § 14-7, at 1189 ("The Framers ... clearly envisioned religion as something special; they enacted that vision into law by guaranteeing the free exercise of religion but not, say, of philosophy or science.") (emphasis in original).

536 See generally Smith, supra note 532. 
understand that belief in a transcendent God makes religious commands compelling to believers in a way that secular beliefs rarely are.

Modern science has identified what seems to be a human instinct for spirituality. "The human brain appears to be organized to ask ultimate questions and seek ultimate answers. ${ }^{538}$ Although this instinct does not validate religion, it means that denying religious freedom may do great violence to the human personality. Some argue that religion should have "the same rights in the public sphere as General Morors, no more and no less." ${ }^{539} \mathrm{At}$ the least, however, religion is one of several "deep commitments" that deserve special legal consideration. ${ }^{540}$ Others see religion as unique, "in part, because it plays such a wide variery of roles in human life."

Religion is also crucial to society. The Founders considered religion essential to public morality. ${ }^{542}$ Many modern social scientists agree. ${ }^{\$ 33}$ Reli-

537 See id. at 154 .

538 Comm'n on Children at Risk, Hardwired to Connect: The New Scientific Case for Authoritative Communities 31 (2003). "The Commission on Children at Risk is a group of 33 children's doctors, research scientists, and mental health and youth service professionals" and is a "jointly sponsored initiative of the YMCA of the USA, Dartmouth Medical School, and the Institute for American Values. Id. at 2; see also George W. Dent, Jr., Religion, Morality and Democracy: New Learning, New Challenges, 2 Geo. J.L. \& Pub. Pol'y 401,431 (2004).

539 Isaac Kramnick \& R. Laurence Moore, The Godless Constitution: The Case Against Religious Correctness I5 (1996); see also Stephen Gey, Why Is Religion Special?: Reconsidering the Accommodation of Religion under the Religion Clauses of the First Amendment, 52 U. PITt. L. Rev. 75, 182 (1990) (favoring an interpretation of the Establishment Clause as "prohibiting accommodation of religiously mandated behavior beyond the scope of religious expression").

540 See Christopher Eisgruber \& Lawrence Sager, The Vulnerability of Conscience: The Constitutional Basis for Protecting Religious Conduct, 6I U. CHI. L. Rev. I245, I285 (1994) (proposing that "state treat the deep, religiously inspired concerns of minority religious believers with the same regard as that enjoyed by the deep concerns of citizens generally"). As contemporary Catholic philosopher John Finnis says, it is "peculiarly important to have thought reasonably and (where possible) correctly about these questions of the origins of cosmic order and of human freedom and reason-whatever the answer to those questions turns out to be, and even if the answers have to be agnostic or negative." John FinNis, Natural Law and Natural Rights 89 ( 1980 ). (2000).

54I Michael W. McConnell, The Problem of Singling Out Religion, 50 DePaul L. Rev. I, 42

542 George Washington said "reason and experience both forbid us to expect that national morality can prevail in exclusion of religious principles." George Washington, Farewell AdDress (Sept. 17, I 796), in Adams \& Emmerich, supra note 535, at I I4. Thomas Jefferson asked "can the liberties of a nation be thought secure when we have removed their only firm basis, a conviction in the minds of the people that these liberties are of the gift of God?" Thomas Jefferson, Notes on Virginia (1784), reprinted in The Life and Selected Writings of Thomas JefFerson i 87, 278 (Adrienne Koch \& William Peden eds., 1944); see also Richard Vetterli \& Gary Brynner, In Search of the Republic: Public Virtue and the Roots of American Government ( 1987 ) (describing the Founders' belief in religion as a source of civic virtue).

543 See, e.g., Daniel Bell, The Return of the Sacred? The Argument of the Future on Religion, in The Winding Passage 324-54 ( 1980 ); see generally Dent, supra note 538, at 419. 
gion can be divisive, but it can also be a source of unity, altruism, and social trust, and has often been so in America. ${ }^{544}$ The Christian tenet of universal brotherhood helps to bridge racial gaps. ${ }^{545}$ Religion aids the economy by promoting personal responsibility, industry, and thrift. ${ }^{546}$ The personal traits cultivated by religion are vital to democracy. ${ }^{547}$ Religion also encourages civic activity. ${ }^{488}$ Religion has been central to major aspects of American history, including the motives of many immigrants, the debate over slavery and the Civil War, and the Civil Rights movement. ${ }^{549}$ The importance of religion is not limited to America or to Western culture. ${ }^{550}$ The significance of religion becomes evident when it is suppressed:

[I]t has historically been replaced by other beliefs, such as the Nordic myth of Aryan superiority and the ritual of Hitler worship; the anomie of the Sartrean; the complete cultural obsession with the tonality of the body, the filling of the 'soul' with the hedonic; and the passion for violence that gives rise to school killing sprees.

Some gay activists hope to abolish religious disapproval of homosexuality without impairing other aspects and the social benefits of religion. They hope in vain. For most believers the tenets of their faith are not separable-they must be taken entirely or not at all. That is why many sects prescribe a creed and why members who defy an article of faith may be declared heretics and excommunicated.

544 See Steinfels infra note 548.

545 See George W. Dent, Jr., Race, Trust, Altruism, and Reciprocity, 39 U. Richmond L. Rev. I00 I, I035-36 (2005).

546 See Robert J. Barro \& Rachel M. McCleary, Religion and Economic Growth Across Countries, 68 AM. Soc. Rev. 760, 77I (2003) (stating that "religion affects economic outcomes mainly by fostering religious beliefs that influence such traits as honesty, work ethic, thrift, and openness to strangers") (citation omitted); Luigi Guiso, et al., People's Opium?? Religion and Economic Attitudes, 50 J. MONETARY ECON. 225 (2003) (stating that "religious beliefs are associated with ... higher per capita income").

547 Madison referred to the "qualities in human nature which justify a certain portion of esteem and confidence. Republican government presupposes the existence of these qualities in a higher degree than any other form." The Federalist No. 55 (James Madison).

548 See Peter Steinfels, Beliefs, N.Y. Times, May 4, 1996, at Aro (referring to "studies showing that two-thirds of those people active in social movements were religiously motivated and that people active in churches and synagogues were more likely to vote and more likely to give time and money not only to religious causes but to secular charities as well").

549 See Dent, supra note 538 , at 427-28.

550 "[T] here are cultural codes embedded in national cultures and ... those cultures, however transformed over time, are ultimately derived from religious belief." Robert N. Bellah, The Protestant Structure of American Culture: Multiculture or Monoculture, 4 HedgeHog Rev. 7, I3 (Spring 2002).

55 I Stephen G. Post, Human Nature and the Freedom of Public Religious Expression $152(2003)$. 
Of course, the major faiths are not monolithic; some strains of Christianity and Judaism now condone homosexuality. Even conservative denominations are not immutable; over 2,000 years the Catholic church has changed its stance on many issues. ${ }^{552}$ Still, traditionalist branches will not approve homosexuality in this century, if ever. In some European countries gay rights are ascendant because traditional sects have dwindled to insignificance. That, too, will not happen in this century, if ever, in America. Conservative sects are growing in numbers and political influence here, as evidenced by their centrality in the success of the Republican Party since 1980 and in the passage of constitutional amendments to protect traditional marriage in all eleven states where they were on the ballot in 2004. ${ }^{553}$

In sum, religious freedom deserves to be taken seriously. If the gay rights movement and traditional religion are to avoid an interminable war devastating to America's social fabric, a truce must be sought.

\section{Resolutions}

1. Equal Rights Or Special Rights? - Gay activists claim that they seek only equal rights. ${ }^{554}$ Opponents charge that they seek special rights. ${ }^{555}$ Both characterizations have an element of truth, but both are misleading. Antidiscrimination laws restrict freedom to choose, a restriction American law imposes only in special cases. Thus these laws have exceptions; even race may be a basis for hiring discrimination. A prison boot camp, for example, may consider race when hiring instructors. ${ }^{550}$ Antidiscrimination laws cover only certain activities so as to preserve a sphere of autonomy. They do not intrude on what are deemed personal choices even in matters of commerce; like where to shop, what records to buy, what lawyer to hire. For reasons of personal freedom, religion is another common basis for exceptions to antidiscrimination laws.

These laws generally protect immutable characteristics, especially race, gender, and physical disability. Homosexual orientation may be immutable but homosexual behavior is not. Discrimination based on behavior, even on past behavior that cannot be changed, does not violate the principle

552 See generally John T. Noonan, Jr., A Church That Can and Cannot Change: The Development of Catholic Moral Teaching (2005).

553 See James Dao, Same-Sex Marriage Issue Key to Some G.O.P. Races, N.Y. Times, Nov. 4, 2004, at 4 .

554 See Stephen H. Miller, And 'Special Rights' For All, Indep. Gay Forum, May 1999. http://www.indegayforum.org/news/show/268 18.html.

555 See Erin Blad, Colorado Contemplates Special Rights for Homosexuals, Citizenlink.com, Mar. 17, 2005, http://www.citizenlink.org/CLFeatures/A000000265.cfm

556 See Wittmer v. Peters, 87 F.3 916 (7th Cir. 1996) (holding it constitutional for a prison boot camp to hire drill instructors on the basis because race was crucial to their effectiveness); see also City of Richmond v. J.A. Croson Co., 488 U.S. 469, 512 n.2 ( 1989) (Stevens, J., concurring). 
of equal concern and respect ${ }^{557}$ and is generally not forbidden at all. An employer may, for example, prefer alumnae of her alma mater, fellow fans of her favorite sports team, or those who share her political views. The one form of behavior on which discrimination is often prohibited is religion. Thus the gay movement collides with religious freedom. The competing interests must be balanced, but the process cannot be mathematical or mechanical. All antidiscrimination laws (indeed, all prohibitory laws) protect some people by preventing others from acting as they wish; that is, they comfort some by discomfiting others. Enacting antidiscrimination laws requires a political judgment that the pain they prevent is more important, more worthy of respect, than the pain they inflict.

In sum, although the gay movement does not seek unique treatment, it does seek status that is conferred only in exceptional cases. There is no general understanding in our law that a claim to freedom from discrimination should trump a claim for freedom to choose, especially when the basis for choice is religion.

2. Equal Respect for Homosexuality?-American society is not morally obliged to treat homosexuality and heterosexuality equally. Despite some assertions that the liberal state must be morally neutral, ${ }^{558}$ all polities do, and indeed must, promote some ways of living over others; no society can be morally neutral. ${ }^{559}$ Some societal moral preferences concern material conditions: wealth is better than poverty; health is better than sickness. Other preferences are metaphysical but considered part of human flourishing. Even liberal states promote art, music, and natural beauty because they are intrinsically good. In so doing, the state necessarily makes value judgments about what is good or bad art and music and what in nature is beautiful or desirable. Antidiscrimination laws are not morally neutral; they

557 See Gerald Dworkin, Equal Respect and the Enforcement of Morality, 7 Soc. PHIL. \& PoL'Y 180, I93 (1990); Andrew Koppelman, Is It Fair To Give Religion Special Treatment?, 2006 ILL. L. REv. 571,581 .

558 See Ronald Dworkin, Taking Rights Seriously 274 ( 1977 ) ("the liberal conception of equality prohibits a government from relying on the claim that certain forms of life are inherently more valuable then [sic] others"); Bruce Ackerman, Why Dialogue?, 86 J. PHIL. 5, 16-1 7 (1989) ("We should ... put the moral ideals that divide us off the conversational agenda of the liberal state.").

559 For one thing, "the claim that the law ought to be morally neutral ... is itself a moral claim." Robert P. George, The Clash of Orthodoxies 75 (200I). To decide what interests to protect, "we need to be able to make decisions about value." Koppelman, supra note 557, at 581. "[S]ome amount of discretion is unavoidable." Id. at 574. Charles Taylor speaks of "discriminations of right or wrong, better or worse, higher or lower, which are not rendered valid by our own desires, inclinations, or choices, but rather stand independent of these and offer standards by which they can be judged." Charles Taylor, Sources of the Self: The Making of the Modern Identity 4 ( 1989 ); see also Martha C. Nussbaum, Women and Human Development: The Capabilities Approach I I-I5 (2000) (discussing the necessity of setting priorities as to which interests are most important). 
evince a judgment that certain conditions or behavior warrant protection while others do not, and that some personal choices regarding the protected categories are improper and should be forbidden.

Liberal societies should be cautious in making moral choice; we should accept and even applaud reasonable variety. We should take particular care as we move from promoting metaphysical goods through government subsidies and the expressive use of law to coercing or punishing those who transgress the official preferences. Thus it is fortunate that homosexual acts are no longer crimes in America. All people deserve to be treated decently and to be free from arbitrary, gratuitous restrictions. That does not mean, however, that disapproval of homosexuality should be punished.

Society may prefer heterosexuality as intrinsically better than homosexuality. Like the value of art, music, or beauty, this norm cannot be empirically proved. Like art, music, and beauty, heterosexual love has been valued by all cultures. This universality suggests that heterosexual love accords with human nature and promotes individual and social well-being. ${ }^{560}$ Society may also decide that it is intrinsically good for adults to bear children and raise them within (a necessarily heterosexual) marriage. ${ }^{561}$ Even some gay activists concede that heterosexuality is superior because of its reproductive capacity. ${ }_{563}^{562}$ Traditional marriage also promotes gender and class equality.

Society may also promote traditional marriage for the benefit of children. The benefits to a child of living with her or his biological parents who are in a stable, traditional marriage are well-documented. ${ }^{564}$ All society

560 This determination could rest in part on a judgment that monogamy is better than promiscuity and that male homosexuals are prone to promiscuity. See infra note 572.

56 I See Stephen L. Carter, Liberal Hegemony and Religious Resistance: An Essay on Legal Theory, in Christian Perspectives on Legal Thought 47 (Michael W. McConnell et al. eds., 2001) ("Most people ... see the value of children ... without the need for explanation. It is not merely an instinct but part of their vision of the good.").

562 Andrew Sullivan acknowledges

a difference that is inherent between homosexual and heterosexual adults. The latter group is committed to the procreation of a new generation. The former simply isn't .... The timeless, necessary, procreative unity of a man and a woman is inherently denied to homosexuals; and the way in which ... parenthood transforms their relationship, is far less common among homosexuals than among heterosexuals.

Andrew Sullivan, Virtually Normal: An Argument About Homosexuality 196 ( 1995 ).

563 See George W. Dent, Jr., Traditional Marriage: Still Worth Defending, I9 BYU J. Pub. L. $419,436-38$ (2004) (describing the aspects of good citizenship learned by children in a good homes).

564 See Robin Fretwell Wilson, Evaluating Marriage: Does Marriage Matter to the Nurturing of Children, 42 SAN DIEgo L. Rev. 848, 858-76 (2005) (reviewing recent studies); Blaine Harden, 2 Parent Families Rise After Change in Welfare Laros, N.Y. Times, Aug. I2, 200 I, at A I "“[A] powerful consensus has emerged in recent years among social scientists .... From a child's point of view, according to a growing body of social research, the most supportive household is one 
profits when children are well cared for. ${ }^{565}$ With fertility rates plummeting in the United States and other industrialized countries, society may favor traditional marriage to induce a higher birth rate. ${ }^{566}$ The breakdown of close-knit families often heralds the decline of a civilization. ${ }^{567}$ Society may promote traditional marriage and family to prevent this.

However, it is hard to deploy tangible benefits to promote traditional marriage. ${ }^{568}$ Society can best encourage traditional marriage through the expressive function of law-by making traditional marriage normative. Ending official preference for traditional marriage would not cause an upsurge of homosexuality because people's sexual inclinations are largely immutable, but it could increase indifference to marriage. Although countries that validate same-sex relationships have not witnessed a boom in gay marriages, ${ }^{569}$ they have experienced a decline in traditional marriages. ${ }^{570}$ The legal change seems to evince a social judgment that traditional marriage is not particularly desirable. The result may be a loss of the benefits of traditional marriage for both children and adults.

Some gay activists argue that principles of equality demand that society treat gay marriage the same as traditional marriage. Apart from the legitimate policy concerns that favor traditional marriage, this argument lacks consistency. If society must be neutral about marriage, it cannot favor marriage over bachelorhood, nor monogamy over polygamy. Some scholars, both gay and heterosexual, make this argument. ${ }^{571}$ This position has the

with two biological parents in a low-conflict marriage.").

565 See Dent, supra note 563, at 438-39.

566 For a discussion of the global decline in fertility rates and its likely repercussions, see Phillip Longman, The Empty Cradle (2004); Ben J. Wattenberg, Fewer (2004).

567 See generally Carle C. Zimmerman, Family and Civilization (1947).

568 See Wilson, supra note 564 , at $878-80$ (discussing the difficulty of formulating programs to promote marriage).

569 See id.

570 See Chris Crain, Editorial, Gays May Ruin "Traditional Marriage," N.Y. Blade, Aug. 3, 200I, at 14 ("The effect on 'traditional marriage' has been dramatic. In France, where [domestic partnerships] first became available in 1999, some I4,000 couples signed up the first year, and almost half of them heterosexual."). This effect was predicted by some gay activists; Janet Halley, Recognition, Rights, Regulation, Normalisation: Rhetorics of Justification in the SameSex Marriage Debate, in Legal Recognition of Same-Sex Partnerships: A Study of National, European and International Law ioi (Robert Wintemute \& Mads Andenaes, eds., 2001) ("recognition of same-sex marriage might lend new momentum to the long-running erosion of the specialness of marriage"); see also id. at 103 (stating that recognizing domestic partnerships "may render marriage a little bit less paradigmatic.").

571 See Martha Fineman, The Neutered Mother, the Sexual Family, and Other Twentieth Century Tragedies 228-30 (1995) (arguing for abolition of marriage as a legal category); Martha M. Ertman, Marriage as a Trade: Bridging the Private/Private Distinction, 26 HARv. C.R.-C.L. L. REv. 79 (2001) (arguing for treating personal relationships through contract rules modeled on corporate law); Tamar Lewin, For Better Or Worse: Marriage's Stormy Future, N.Y. Times, Nov. 23, 2003, at DI ("The most radical structural change being discussed these days is taking the state out of the marriage business."). 
virtue of consistency, but most gay activists shun it because most people see valid reasons for society to prefer monogamous marriage.

Several diseases are spread by the promiscuity common among gay man. ${ }^{572}$ Single men generally are more likely than married men to abuse drugs and commit crimes and be less successful in the job market. Traditional (i.e., heterosexual monogamous) marriage civilizes people (especially men), discouraging their promiscuity and channeling their energies in productive directions. ${ }^{5 / 3}$ Society can justly favor heterosexuality in order to promote the benefits of traditional marriage-good health, obedience to the law, and high job performance.

3. Freedom of Expression.-Gay activists appreciate the power of traditional religion in America and understand that homosexuality will not attain legal and social equality so long as many Americans freely express the disapproval of homosexuality taught by traditional religions. Hence, the gay movement seeks to suppress such expression. The First Amendment has often

572 See Dennis altman, The Homosexualization of America, The Americanization of THE HoMOsEXUAL I 87 ( 1982 ) ("[A]mong gay men a long-lasting monogamous relationship is almost unknown."); BELL \& WEINBERG, supra note 526, at 85 ("Almost one-half of the white homosexual males ... and one-third of the black homosexual males ... said that they had had at least five hundred different sexual partners ...."); Warren Winkelstein, Jr. et al, Sexual Practices and Risk of Infection by Human Immuno-deficiency Virus: The San Francisco Men's Health Study, 257 JAMA 32 I, 325 (1987) (linking the spread of AIDS to gay male promiscuity). Claims that promiscuity among gay men is not natural but stems from its social stigmatization are implausible. In the last decade, despite rapid growth in the social acceptance of gays, venereal diseases proliferated among gay men, especially in urban areas where they are most accepted. See Michael Specter, Higher Risk, New Yorker, May 23, 2005, at 38, 39. Gay men may not be naturally more promiscuous than heterosexual men; in all societies men are more promiscuous than women. See David P. Schmitt, Universal Sex Differences in the Desire for Sexual Variety: Tests from 52 Nations, 6 Continents, and 13 Islands, 85 J. Personality \& Soc. Psychol. 101 (2003). But heterosexual marriage tends to curb promiscuity. The relative risk of contracting AIDS from homosexual conduct has been estimated to be fifty times the risk from heterosexual conduct. See Eugene Volokh, Same-Sex Marriage and Slippery Slopes, 33 Hofstra L. Rev. I I55, I I 99 n. 133 (2005) (using figures from the Centers for Disease Control).

573 Some believe gay marriage can do the same for gay men. See William N. EsKridge, JR., The Gase for SAME-SeX Marriage 85 (1996) (validating gay marriage would "civilize gay men by making them more like lesbians"); Jonathan Rauch, GaY MarRiage: WhY It Is GOOD FOR GAYS, GoOd fOR STRAights, AND GoOd fOR AMERICA I9-2I (2004); Sullivan, supra note 562, at 112 ; Evan Wolfson, Crossing the Threshold: Equal Marriage Rights for Lesbians and Gay Men and the Intra-Community Critique, 2 I N.Y.U. Rev. L. \& Soc. Change 567, 580 (1994-95) (positing a "transformational potential of gay people's inclusion ... in marriage"). This is dubious. Where gay marriage is recognized, few gay men marry. See Symposium, Has the Supreme Court Gone Too Far?, CommenT., Oct. 2003, at 25, 48 (comments of James Q. Wilson) ("In the Netherlands, which legalized same-sex marriages in 2001, fewer than ten percent of an estimated 50,000 same-sex couples have chosen marriage."). Gay relationships tend to be shortlived. See Maria Xiridou, et al., The Contribution of Steady and Casual Partnerships to the Incidence of HIV Infection Among Homosexual Men in Amsterdam, 17 AIDS 1029, 103 I (2003) (stating that gay male partnerships lasted on average 1.5 years and that men in the partnerships had an average of eight casual sexual partners per year). 
squelched these efforts. Ironically, unintended support for free speech comes from gays who poignantly testify to the agony of having to conceal one's identity: it "undermines the authenticity of one's life, disrupts relationships with others, and hurts those whom one marries or otherwise implicates in the lie."

Courts have been unanimous in striking down speech codes in public universities despite claims that these codes forbid only "fighting words" or harassment. ${ }^{575}$ Unfortunately, many public universities retain speech codes that chill protected speech; the costs of challenging such codes is so high that few bother to sue, and the schools realize that their costs are small even if they lose. Procedures and remedies should be improved so that unconstitutional speech codes are strongly deterred. Although the First Amendment governs only state action, Congress, state, and local lawmakers and private organizations can protect speech in private contexts and have sometimes done so. California's Leonard Law, for example, extends free speech to private colleges in that state. ${ }^{576}$ Congress should adopt a similar law to cover all universities that receive federal funds.

For government employees, the Supreme Court in Pickering required a balancing "between the interests of the [government employee] as a citizen, in commenting upon matters of public concern and the interests of the State, as an employer, in promoting the efficiency of the public services it performs through its employees." ${ }^{57}$ This verbal formula is fine. Sadly, lower courts often construe the test to allow government employers to silence criticism (including religiously based criticisms) of homosexuality. Personal vilification should be forbidden, but general statements critical of homosexuality should be permitted unless they exhort violence. The same standard should apply to government contractors.

Some freedom of speech should also be mandated for many private workplaces. Arguably, it already is for religiously inspired speech: the Civil Rights Act forbids religious discrimination. ${ }^{579}$ Employment rules that bar criticism of homosexuality have a disparate impact on religious people. Unfortunately, courts require only a de minimis burden on the employer to override an employee's religious expression. ${ }^{580}$ Admittedly, a workplace differs from a college campus. The latter should be a marketplace of ideas; in the former, the need for cooperation demands civility. Civility, however, does not require suppression of all speech that someone dislikes. Congress

574 EskRIDGE, supra note 530, at 307. To his credit, Eskridge argues that free expression for gays will give "the majority ... an incentive to speak as well." Id. at 306.

575 See supra notes $335-67$ and accompanying text.

576 CAL. Educ. Code $\$ 94367$ (West 2006); see supra note 486 and accompanying text.

577 Pickering v. Bd. of Educ., 391 U.S. 563, 568 (1968).

578 See supra part II-B-2.

579 See supra notes $53-66$ and accompanying text.

580 See supra notes $64-65$ and accompanying text. 
should require a showing of substantial need to suppress religious expression. That requirement would dictate a different result in cases like Bodett, Peterson, and Buonanno. ${ }^{581}$ Of course, the same freedom (and the same insistence on civility) should also extend to assertions of gay rights and criticism of its opponents.

4. Discrimination in Employment and Services.-Virtually all agree that discrimination based on homosexuality should sometimes be allowed. Few would forbid religious organizations to exclude homosexual clergy. Other cases are harder. The Catholic Church would permit discrimination in "adoption and foster care, the employment of teachers and athletic coaches and military recruitment." ${ }^{582}$ In many cases gays are accepted so long as they keep their sexuality private. In effect, many employers follow the military's "don't ask, don't tell" policy. Some gays must forego their preferred occupation or location or conceal their private lives in ways not required of others, but gays enjoy a higher average income than other Americans.

The scope of freedom to choose depends on the context in which the freedom is claimed. One contextual distinction is between government and private-sector activity. The state differs from private employers in several ways. It holds a monopoly over many activities and thus over anyone who seeks employment there. The state is also free of the discipline of the market and of the cost that private employers pay for inefficient discrimination. State action also has a unique social significance because of its expressive power.

As an employer, government should ignore an individual's religion and private behavior, including legal sexual activity, unless it is material to one's ability to perform a job, which is rarely the case. ${ }^{584}$ Government should also disregard religion and sexual orientation in selecting government contractors. Government contractors themselves, however, are private entities and should be subject only to the same laws as other private employers.

The practical need to prohibit discrimination based on sexual orientation by private employers is unclear. Some gays experience discrimination,

58I These cases are discussed supra at notes $455-97$ and accompanying text.

582 Robert Nugent, The U.S. Catholic Bishops and Gay Civil Rights: Four Case Studies, $3^{8}$ Cath. Law. I, 5 (1998) (discussing Some Considerations Concerning the Response to Legislative Proposals on the Non-Discrimination of Homosexual Persons, a statement by the church's Congregation for the Doctrine of the Faith, which is printed in full in Vorces OF HOPE: A Collection of Positive Catholic Writings on Gay and Lesbian Issues 229-33 (Jeannine Gramick \& Robert Nugent eds., I995)).

583 See supra note 7 .

584 The major exception is the military. See Goldman v. Weinberger, 475 U.S. 503 (1986) (acknowledging the special character of, and deference afforded to, the military). The propriety of this exception depends on military effectiveness and not on a balancing of gay rights and religious freedom, so it is beyond the scope of this article. 
but many do not, and gays have a higher average income than others. ${ }^{585}$ The size of an organization is relevant. Even if the law does not forbid private entities to discriminate against homosexuals, there is rarely any justification for large organizations to do so. Discrimination by a small entity is of less concern because its jobs are less likely to be unique in its locale; an individual it rejects can probably seek a similar job elsewhere. Also, a small employer is more likely to sincerely cultivate a particular religious and moral atmosphere in the workplace. The same considerations apply to discrimination by private service and housing providers and users of public facilities. ${ }^{586}$ Government contractors should not be subject to special employment restrictions unrelated to the purpose of the contract.

In general, government should not discriminate on the basis of religion or of sexual orientation in providing services, whether through its own agencies or through private contractors. Discrimination by government contractors should be tolerated only if the burden on the group discriminated against would be small and the detriment of any discrimination is outweighed by marginal benefit of using the contractor that discriminates instead of other contractors that do not. This test will rarely be satisfied, but there are some exceptions, such as the adoption services offered by Catholic Charities of Massachusetts.

Private employers should generally be able to forbid sexual orientation discrimination by employees. Although the Civil Rights laws forbid religious discrimination, their protection is limited, almost ephemeral, because the duty to accommodate religious practice is overridden by any minor need of the employer. ${ }^{588}$ Although employers should not be required to suffer major financial costs to accommodate religious employees, they should at least be required to show that accommodating an employee would cause more than de minimis cost or disruption, as is required for accommodation of physical and emotional disabilities. ${ }^{589}$ The required accommodation should include tolerance of religious statements about homosexuality so long as they meet reasonable time, place, and manner rules and do not slide into harassment.

The freedom of expressive associations is now unclear. ${ }^{590}$ The decisions in Hurley and Dale are welcome, but they leave crucial questions. First,

$5^{85}$ See supra note 7 . In jurisdictions that have antidiscrimination laws, few suits have been filed. See Sullivan, supra note 562, at 157 .

586 See supra notes 103-35, 252-69, and accompanying text.

587 See supra note $235-47$ and accompanying text.

588 See supra notes $53-66$ and accompanying text.

589 In such cases the Americans with Disabilities Act, 42 U.S.C. $\$ 12111$ ( 10 ) requires "reasonable accommodation" unless it would impose "undue hardship," which is defined to mean "significant difficulty and expense." Thus the holding in Bruff seems right, but Bodett, Peterson, and Buonanno seem wrong. See supra notes $444-80$ and accompanying text.

590 See supra notes $455-501$ and accompanying text. 
what is an expressive association or expressive event? Many non-profit organizations are church-affiliated or embrace some religious principles. Many of them do not cultivate moral values as the Boy Scouts do, but their purpose is at least as "moral" as that of the Council in Hurley. Especially because they are non-profit, these organizations should be treated as expressive associations. At the least, they should be exempt from employment laws that would force them to violate their religious commitment. Such an exemption recognizes that religion is not limited to worship and preaching. ${ }^{592}$ A related question is the status of business firms that have a religious commitment. A decent respect for religious freedom would allow firms generally to pursue their religious commitment if they can show that it is substantial and sincere, unless the exemption would severely burden many people.

Another issue is who defines the purpose of an expressive association. It is appalling that in Dale, four Supreme Court justices rejected the Boy Scouts' statement of its moral principles and substituted their own definition of those principles. ${ }^{594}$ True, the Scouts had not always said unequivocally that homosexuality violates Scout values. Individuals and organizations are often unclear about their stand on certain issues; the Supreme Court itself often fails to make its positions clear. Such a failure does not mean that, when the individual or entity does take a stand, the position announced is less sincere or important than positions he or it have long made clear. Indeed, that a stated position conflicts with prior statements does not mean that it is not sincere or important to the speaker. Again, the Supreme Court itself sometimes reverses itself.

Of course, courts should be wary of sham claims of religiosity, but there was no reason to question the sincerity of the Boy Scouts' stand on homosexuality. It is hard to imagine that the dissenters in Dale would have challenged a claim of a liberal entity like the ACLU about its own position on some issue. It seems that the dissenters rejected the Scouts' asserted position on homosexuality simply because they disliked that position.

An expressive group's claim that a law seriously impedes the expression of its message merits less deference. In Roberts $v$. United States Jaycees, for example, the Court held that the Jaycees had "failed to demonstrate ... any

591 Many statutory exemptions for religious organizations now are not so broad. See Magid \& Prenkert, supra note 134, at 3, 3 n.46; Susan J. Stabile, State Attempts to Define Religion: The Ramifications of Applying Mandatory Prescription Contraceptive Coverage Statutes to Religious Employers, 28 Harv. J.L. \& PuB. PoL'y 741, 748, 755 (2005).

592 See Stabile, supra note 591, at 755-64.

593 See supra notes 124-35 and accompanying text; see also McConnell, supra note 504, at 254 (stating a similar position).

594 Boy Scouts of Am. v. Dale, 530 U.S. 640 (2000) (Stevens, J., Souter, J., Ginsburg, J., and Breyer, J., dissenting.)

595 See, e.g., Lawrence v. Texas, 539 U.S. 558 (2003), overruling Bowers v. Hardwick, 478 U.S. 186 (1986). 
serious burden on the male members' freedom of expressive associarion" from a law requiring the admission of women to its membership. ${ }^{596}$ However, if the claim of a serious impediment is found to be sincere, it deserves considerable deference. The dissenters in Dale argued that the law there only forbade the Scouts to discriminate in hiring; it did not stop them from disseminating disapproval of homosexuality. This distinction ignores the importance that philosophers and theologians have always given to acting in accord with one's beliefs.

An expressive group's interests must be weighed against the state's interest in imposing a law. In Dale, the Court eschewed the intermediate $O^{\prime} B r i e n{ }^{598}$ test which, it said, applies only when a law "has only an incidental effect of protected speech ....." Instead, it applied "traditional First Amendment analysis," which presumably entails the compelling interest standard. ${ }^{600}$ A subsidiary question is when a member's or employee's role in an organization is such that overriding its selection criteria seriously interferes with its message. In Dale, the Court found that the position of assistant scoutmaster was sufficiently important, but in Roberts mere membership in the Jaycees was not important enough. Subsequent lower court cases suggest a line between "expressive" and "nonexpressive positions," which makes sense.

Again, all these principles should apply equally to both sides of the debate over homosexuality. Some employees and organizations have a religious commitment to support the gay movement. They should enjoy the same freedoms of expression and association as those who disapprove of homosexuality on religious grounds. The dispute between the gay movement and traditional religion should not be treated like the dispute between the civil rights movement and racism, but more like the competition between political parties. Each side must allow the other to publicize its message, but neither side is required to concede that the other side is right or worthy of honor.

5. The Expressive Role of Law and Government.-Many gay activists care more about the expressive function of antidiscrimination laws than about their practical effect. ${ }^{602}$ Although most Americans now tolerate homosexu-

596 Roberts v. U.S. Jaycees 468 U.S. 609, 626 (1984).

597 See Stabile, supra note 591, at 759-64.

598 United States v. O'Brien, 391 U.S. 367 (1968).

599 Boy Scouts of Am. v. Dale, 530 U.S. 640, 658 (2000).

600 See supra notes $45-50$ and accompanying text.

601 See supra notes $410-13$ and accompanying text.

602 See McConnell, supra note 504, at 255 (suggesting that gay antidiscrimination laws "may be desired largely as a symbolic measure: to convey government support for the notion that the refusal to associate or contract with homosexuals is bigoted and immoral"). Advocates of legal recognition of same-sex marriage often stress its symbolic function. See Halley, supra 
ality, most gays seek "not merely a grudging social toleration, but full social acceptance ...." ${ }^{603}$ As well as fixing tangible benefits and burdens, law performs an expressive function by "expressing social values and in encouraging social norms to move in particular directions." ${ }^{604}$ This is important because material sanctions often cannot change behavior and attitudes. ${ }^{605}$ Thus battles often rage over purely symbolic government acts, like the recent resolution of the United States Senate apologizing for not outlawing lynching many years ago. ${ }^{606}$ Observing an official Gay Pride Day, for example, creates no legal rights, but it connotes social approval of gays. Antidiscrimination laws serve both practical and symbolic purposes; they impose penalties and also signify social acceptance of homosexuality.

In addition to symbolic steps, government supports certain values by its own speech; it need not be content-neutral. ${ }^{608}$ Public schools may" promote civic virtues" and "inculcat[e] fundamental values necessary to the maintenance of a democratic political system ...., ${ }^{609}$ Learning "in public schools is not confined to books, the curriculum, and the civics class; schools [also] teach by example the shared values of a civilized social order." ${ }^{610}$ Indoctrination in public schools can be effective because students are impressionable and a captive audience in school for over a thousand hours every year. Even considering whatever children experience at home, they are likely to consider attitudes promulgated in school as the norm for public behavior.

Many people who do not discriminate against gays nonetheless disapprove of homosexuality and do not want government to condemn their morals. ${ }^{611}$ The desire of gays for official endorsement is understandable, but it is also understandable why many people oppose it. Disapproval of

note $57^{\circ}$, at 97,98 .

603 Romer v. Evans, 517 U.S. 620, 646 (1996) (Scalia, J., dissenting).

604 Cass R. Sunstein, Social Norms and Social Roles, 96 Colum. L. Rev. 903, 953 (1996).

605 "[A] social order based on laws can be maintained without massive coercion only if most people most of the time abide, as a result of supportive social norms, by the social tenets embedded in the law ...." Amitai Etzioni, The Monochrome Society 171 (2001). Material incentives to influence behavior are often expensive and may be counterproductive. See Dan M. Kahan, The Logic of Reciprocity: Trust, Collective Action, and Law, 102 MicH. L. Rev. 71 (2003).

606 Lynching Victims Senate Apology, S. Res. 39, Iogth Cong. (2005).

607 See Sullivan, supra note 562 , at 161 (stating that a law barring discrimination against homosexuals "contains an approval of homosexual behavior"); McConnell, supra note 504, at 252 (semble).

608 See Rosenberger v. Rector \& Visitors of Univ. of Va., 5 I 5 U.S. 819, 833 (1995) (stating that when government itself speaks, it may make content-based choices); Rust $v$. Sullivan, 500 U.S. 1 73, 194 (1991) (semble).

609 Ambach v. Norwick, 44I U.S. 68, 77-80 (1979).

610 Bethel Sch. Dist. v. Fraser, 478 U.S. 675, 683 (1986).

61 I See Nugent, supra note 582, at 9-10, 17, 19 (stating that Catholic bishops fear that adding homosexuality to the select list of forbidden bases for discrimination would be perceived by the public as government endorsement of homosexuality). 
homosexuality often stems from religious faith. If government condones homosexuality, in effect it declares that faith false.

Because violence against gays remains common, government should not merely enforce criminal sanctions against those who commit such violence; it should use its expressive role to decry and deter it. Government-especially public schools-should exercise its own speech to correct common falsehoods about homosexuals (e.g., that most homosexuals are child molesters). Government should also educate people about the material benefits of (traditional) marriage both for the married partners and for their children. Otherwise, on questions whether homosexuality is "normal" or morally acceptable, equal to heterosexuality, government should remain neutral. On one hand, this means that government (including public schools) should not celebrate a Gay Pride Day or Day of Silence intended to condone homosexuality. On the other, it means that public facilities and programs (including school facilities and extracurricular programs) must be equally available to homosexual and pro-homosexual groups.

\section{Conclusion}

The legal conflict between the homosexual movement and those who oppose it on religious grounds is intense and likely to grow; neither side is about to obliterate the other. This conflict cannot be resolved by a single legislative or judicial act; it will play out in innumerable skirmishes. However, certain principles should ensure tolerance for both sides. Homosexuals, like all people, should be free from harassment and physical abuse and, in some cases, from discrimination. America has always afforded special deference to religious freedom. That deference should extend to those who have a religious commitment to either side of this debate. All should be free to express their views about homosexuality and, in most cases, to act on those beliefs so long as they avoid harassment and physical abuse. These principles will not end disagreement between the two sides, but they can help assure that the dispute will proceed civilly and with due regard for the rights of all. 
